NNWSI WASTE FORM TESTING AT ARGONNE NATIONAL LABORATORY

$$
\text { UCRL - -21060-87-1 }
$$

DE90 011499

\title{
Semiannual Report
}

January-June 1987

Work Performed by

John K. Bates, Thomas J, Gerding, Teofilo A. Abrajano, Jr.,

William L. Ebert, and James J. Mazer

$$
\text { of }
$$

ARGONNE NATIONAL LABORATORY

Chemical Technology Division

9700 South Cass Avenue

Argonne, Illinois 60439-4837

Novenber 1988

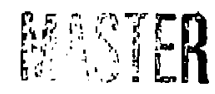




\section{TABLE OF CONTENTS}

Page

I. INTRODUCTION $\ldots \ldots \ldots \ldots \ldots \ldots \ldots \ldots \ldots$

II. UnSATURAted test development and Performance $\ldots \ldots \ldots, 2$

A. NNWSI Unsaturated Test Method ........... 2

B. NNWSI Parametric Experiment ............. 33

$\therefore \quad$ Analog Experiment .............. 55

III. NNWSI GAMMA IRRADIATION TESTING . . . . . . . . 56

A. $2 \times 10^{5} \mathrm{Rad} / \mathrm{hr}$ Experiments ............ 56

B. $1 \times 10^{4} \mathrm{Rad} / \mathrm{hr}$ Experiments .............. 65

C. $1 \times 10^{3}$ and 0 Rad/hr Experiments ........... 65

IV. SURFACE ANALYTICAL SUPPORT $\ldots \ldots \ldots \ldots \ldots \ldots$

A. SIMS software ................ 73

B. Establishment of a Laser Raman

Microprobe Factlity .............. . 77

C. Development of a Gas Arialysis System . . . . . . . 77

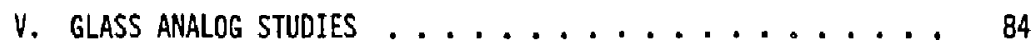

REFERENCES $\ldots \ldots \ldots \ldots \ldots \ldots \ldots \ldots \ldots$ 


\section{$\underline{\text { LIST OF TABLES }}$}

No.

Title

Page

1. Test Matrix and Component Weights for N2 Test Series . . . . 3

2. Solution Analyses (Cations) for the N2 Test Series ..... 9

3. Blank Corrected Solution Results from the N2 Test Series . . 12

4. Normalized Release of Elements from the Glass in

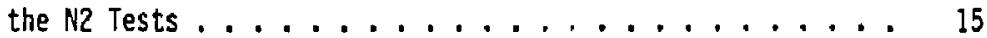

5. Normalized Lithium Release through 52 Weeks of Testing . . . 16

6. Composition of Leachates Collected during the

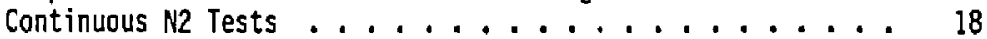

7. Test Matrix and Component Weights for N3 Test Series .... 29

8. ATM-10 Comparative MCC-1 Leach Tests ........... 34

9. Description, Purpose, and Status of Parametric

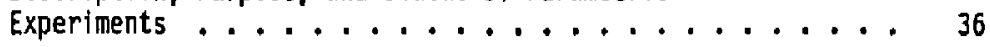

10. Test Conditions for $\mathrm{UO}_{2}$ Tests ................ 38

11. Solution Analysis from $\mathrm{UO}_{2}$ Parametric Tests

Series P-VI ............................. 40

12. Analysis of Solution Composition from P-VI

Experiments ................ 43

13. Experimental Matrix and Results from Parametric

Experiments (P-VIII Series) .............. 46

14. Solution Results (Total Nanograms) for P-VIII

Experimental Series ................ 48

15. Blank Corrected Totals for Parametric P-VIII

Test Series Solutions ............... 49

16. Results from the F-1 Unsaturated Test Serles . . . . . . . 50

17. 1986 Vapor Hydration Experiments for NNWSI ......... 52

Cont'd 


\section{LIST OF TABLES - Cont'd}

No. Title

Page

18. Np and Pu Release from ATM-8 Glasses ............ 62

19. List of Samples Analyzed using Various Surface

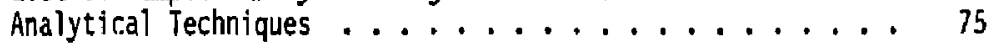

20. Composition of Glass Standards (wt $\%) \ldots . \ldots 8$ 


\section{LIST OF FIGURES}

No. Title

Page

1. Photograph of the Top Surface from Test $N 2 \#$. . . . . 7

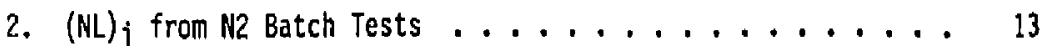

3. (NL) $)_{L i}$ Continuous Tests ................... 16

4. Secondary Electron photomicrograph of the

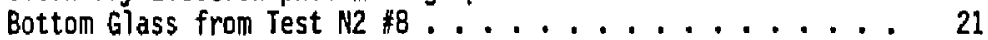

5. Alteration Products and Corresponding EDS Spectira that Formed on the Glass Surface Shown in Fig. $4 \ldots 22$

6. Photomicrograph and EDS Spectra of Alteration Products that Formed on the Top Glass Surface from Test N2 \#6 ................

7. (a) Buildup of Precipitates at the Interface Around the Circumference of the Punched Holes in the Stainless Steel, Bottom Cantster, Test N2 $\$ 2$, Magnification 250x, Marker $=55 \mu m \ldots \ldots 25$ (b) Higher Magnification Micrograph (1200x) of the Central Region of Fig. 4a, marker $=5 \mu \mathrm{m} \ldots \ldots 25$

8. EDS Spectra of Selected Areas Shown in Fig. 7 . . . . . . 26

9. Hicrographs of Pollshed Cross-Sections of Etched Stainless Steel Waste Form Holders for the N2 Test . . . . 27

10. Photomicrograph and EOXS Spectrum of Precipitate Formed on SRL U Glass ................

11. Photomicrograph and EDXS Line Profile of Cross Section of ATM-1C Glass ................ 69

12. SIMS Profile of $7 \mathrm{Li}^{+}$and $23 \mathrm{Na}^{+}$from Sample $4 \hat{z} 3$, Experiment Number G-36l, SRL $U+$ Tuff, $0 \mathrm{R} / \mathrm{h}, \mathrm{BO} d \ldots 72$

13. Resonant Nuclear Reaction Spectroscopy (RNRS) Result for Sample 400, SRL U, O R/h, 180 d ........ 74

14. Raman Spectrum of $\mathrm{CaCO}_{3}$ Obtained Using the Laser

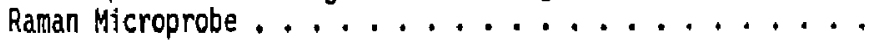

Cont'd 
No. Title

Page

15. Sketch of Temperature Control Unit . . . . . . . . . 79

16. Temperature Ramp Produced using Two Different Heating

Rates (Top) $5^{\circ} \mathrm{C} /$ minute, (Bottom) $10^{\circ} \mathrm{C} /$ minute . . . . . . 81

17. TPD Spectra, $m / e=19$ HDO, of Hydrated Glass . . . . . . 82 
NWWSI WASTE FORM TESTING

Semiannual Report, January-June 1987

John K. Bates, Thamas J. Gerding, Teofilo A. Abrajano, Jr. Wi Iliam L. Ebert, and James J. Mazer

\section{INTRODUCTION}

The Nevada Nucleas Waste Storage Investigation (NNwSI) Project is investigating the tuff beds of Yucca Mountain, Nevada, as a potential location for a high-level radioactive waste repository. As part of the waste package development portion of this project, which is directed by Lawrence Livermore National Laboratory, experiments are being performed by the Chemical Technology Division of Argonne National Laboratory to study the behavior of the waste form under anticipated repository conditions. These experiments include (1) the development and performance of a test to measure waste form behavior in unsaturated conditions and (2) the performance of experiments designed to study the behavior of waste package components in an irradiated environment. Previous reports [STEINDLER; BATES-1, -2] document developments in these areas through 1986. This report summarizes progress during the perfod January-June 1987.

Efforts this perlod have focused on analyzing components from the $\mathrm{N2}$ Unsaturated Test series, writing a topical report describing the $\mathrm{N} 2$ test results, and initlating the $N 3$ Test series using ATM-10 glass. Experiments studying the effect of gamma radlation $\left(1 \times 10^{3}\right.$ and $\left.0 \mathrm{rad} / \mathrm{hr}\right)$ on groundwater composition and SRL 165 type glass reaction have been completed and the results from these experiments are being compiled and the components analyzed. Experiments at 0 Rad/hr using ATM-1C and ATM-8 glasses that are : being done to be comparable with previous experiments done in a radiation field, have been completed through 91 days and two reports describing the effect of radiation on the leaching of these glasses have been written. Parametric experiments evaluating physical factors such as relative humidity on glass reaction are in progress. 


\section{UNSATURATED TEST DEVELOPMENT AND PERFORMANCE}

\section{A. NNiSI Unsaturated Test Method}

1. NNWSI Unsaturated Test Method

Additional procedures have been written and approved by NNWSI that guide analysis of test components generated during the test. While these procedures are not explicitly required according to the Unsaturated Test Method, they will allow several additional analyses to be treated as QA level I data, if desired. These procedures include qualitative description of test components, determination of ferrous iron in glasses, and comparative quantitative analysis of glasses using SEM/EDS/WDS.

\section{N2 Unsaturated Test}

The detalled N2 Test matrix, together with selected results, are presented in Table 1. Tests $\mathrm{N2-1}$ through $\mathrm{N2}-8$ are the batch tests, and tests N2-9 through N2-12 are the continuous tests. At this point the tests have been completed through the 65-week sampling period. All the batch tests have been completed, and three continuous tests and one blank are ongoing. Three types of results including general observations, solution analyses, and component analyses are presented. A combination of each type of result is required to provide a concerted description of the reaction process. Eventually, the results presented here will be combined with a modeling effort to project the long-term performance of the interactions observed in this Test.

\section{a. General Observations}

Unilike the $F$ Test series [BATES-3], where there was a marked disparity in the post-reaction appearance of the components from individual tests, the components from the N2 Test series were quite similar in appearance. General observations were made of the test components prior to, during, and after testing. These observations included color photographs of the pre- and post-test waste form holder sections, visual observation of the glass samples before testing, color photographs of the top and bottom sections after testing, and visual observation of the test components during the sampling periods. 
Table 1. Teat batrix and Component Neights for H2 Test Series

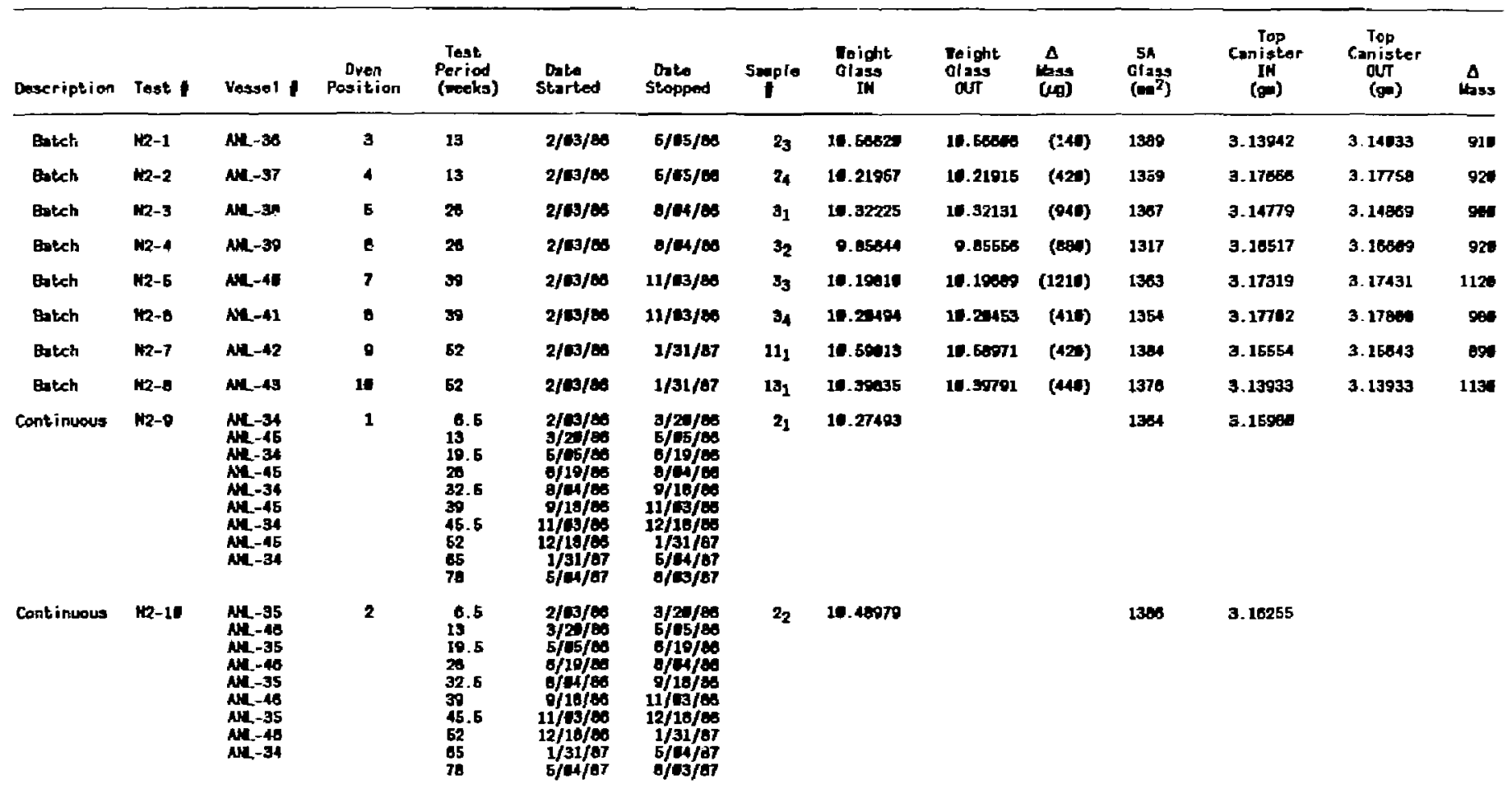


Table 1 (Cont'd)

\begin{tabular}{|c|c|c|c|c|c|c|}
\hline $\begin{array}{l}\text { Botton } \\
\text { Canister } \\
\text { IN } \\
\text { (g) }\end{array}$ & $\begin{array}{l}\text { Botton } \\
\text { Canister } \\
\text { ouT } \\
\text { (g) }\end{array}$ & $\underset{\text { Mass }}{\mathbf{A}}$ & $\begin{array}{c}\text { Total } \\
\text { Vessel } \\
\text { IH } \\
(G)\end{array}$ & $\begin{array}{l}\text { Total } \\
\text { Yessal } \\
\text { ouT } \\
\text { (g) }\end{array}$ & $\underset{\text { Hass }}{\Delta}$ & $\begin{array}{l}\text { Dater } \\
\text { Mdded } \\
\text { During } \\
\text { Teating }\end{array}$ \\
\hline 4.10280 & 4.10391 & 1110 & 1340.4 & 1341.7 & 1.3 & 1.05 \\
\hline 4.66819 & 4.60720 & $11 €$ & 1335.0 & 1350. & 1.3 & 1.95 \\
\hline 4.07221 & 4. Dr3ats & 105: & 1330.4 & 2340.0 & 2.4 & 3.90 \\
\hline 4.09071 & 4.69671 & 88 & 1335.8 & 1338.8 & 3.6 & 3.95 \\
\hline 4.68299 & 4.08452 & 1630 & 1354. & 1334.0 & 4.6 & 6. 85 \\
\hline $4.1207 \theta$ & 4.12998 & 119 & 1339.1 & 1343.1 & 4.0 & 5.85 \\
\hline 4. .79967 & +.68089 & 120 & 1929.6 & 1336.2 & 6.6 & 7.80 \\
\hline 4.18457 & 4.10182 & 1250 & 1320.1 & 1335.6 & 6.5 & $7 . *$ \\
\hline 4. .09714 & & & $\begin{array}{l}1330.5 \\
1329.4 \\
1330.5 \\
1329.5 \\
1338.7 \\
1329.5 \\
139.6 \\
1329.4 \\
1336.4 \\
1329.9\end{array}$ & $\begin{array}{l}1337.2 \\
1334.6 \\
1337.2 \\
1334.2 \\
1337.0 \\
1330.2 \\
1337.1 \\
1229.0 \\
1337.8\end{array}$ & $\begin{array}{r}+1.7 \\
+11.6 \\
+1.7 \\
+\$ .7 \\
+1.1 \\
+1.7 \\
+1.5 \\
+1.5 \\
+1.5\end{array}$ & $\begin{array}{r}9.975 \\
0.975 \\
.975 \\
.975 \\
. .975 \\
6.975 \\
.975 \\
.975 \\
1.96\end{array}$ \\
\hline 4.12307 & & & $\begin{array}{l}1397.9 \\
1341.4 \\
1338.6 \\
134 . .6 \\
1338.4 \\
1341.6 \\
1338.4 \\
1341.5 \\
1397.9 \\
1341.6\end{array}$ & $\begin{array}{l}1338.5 \\
1342.1 \\
1339.8 \\
1342.2 \\
1338.8 \\
1342.3 \\
1338.7 \\
1342.2 \\
1339.4\end{array}$ & $\begin{array}{r}+4.6 \\
+4.7 \\
+4.6 \\
+4.6 \\
+4.7 \\
+4.7 \\
-4.7 \\
+1.5\end{array}$ & $\begin{array}{r}0.975 \\
6.975 \\
.975 \\
.975 \\
.975 \\
.975 \\
.975 \\
2.975 \\
1.95\end{array}$ \\
\hline
\end{tabular}


Table 1 (Cont'd)

\begin{tabular}{|c|c|c|c|c|c|c|c|c|c|c|c|c|c|c|}
\hline Description & Text: & Vestel I & $\begin{array}{l}\text { Oven } \\
\text { Pasition }\end{array}$ & $\begin{array}{l}\text { Test } \\
\text { Poriod } \\
\text { (wroks) }\end{array}$ & $\begin{array}{l}\text { Date } \\
\text { Startod }\end{array}$ & $\begin{array}{l}\text { Date } \\
\text { Stopped }\end{array}$ & sapple & $\begin{array}{l}\text { Toight } \\
\text { Giass } \\
\text { II }\end{array}$ & $\begin{array}{l}\text { Taight } \\
\text { Glast } \\
\text { ourt }\end{array}$ & $\underset{(\text { (as) }}{\Delta}$ & $\begin{array}{c}S A \\
\text { Glass } \\
\left(\infty 0^{2}\right)\end{array}$ & $\begin{array}{c}\text { Top } \\
\text { Conister } \\
\text { IM } \\
\text { (g) }\end{array}$ & $\begin{array}{c}\text { Top } \\
\text { Canister } \\
\text { OUT } \\
\text { (ga) }\end{array}$ & Hess \\
\hline Blant & H2-11 & 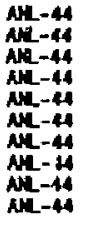 & 11 & $\begin{array}{l}6.5 \\
13 \\
19.5 \\
28 \\
32.5 \\
39 \\
45.5 \\
82 \\
64.5 \\
65 \\
70\end{array}$ & 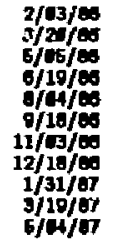 & 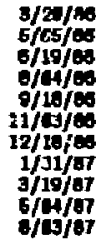 & nones & & & & & & - & \\
\hline Continuous & $1+2-12$ & $\begin{array}{l}N L-30 \\
N L-37 \\
M L-30 \\
N L-31 \\
N A-30 \\
M L-37 \\
M L-36 \\
M L-37 \\
N L=36\end{array}$ & $\mathbf{3}$ & $\begin{array}{l}0.6 \\
13 \\
18.5 \\
28 \\
32.5 \\
30.5 \\
45.5 \\
62 \\
65\end{array}$ & 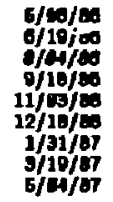 & 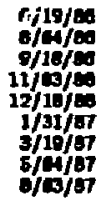 & $13_{2}$ & 16.04070 & & & $13 e 4$ & 3.1677 & & \\
\hline
\end{tabular}

-Inlet liro pluggod during tho tost pariod. 
Tablo 1 (Cont'd)

\begin{tabular}{|c|c|c|c|c|c|c|}
\hline $\begin{array}{l}\text { Aotton } \\
\text { Canister } \\
\text { IN } \\
\text { (G) }\end{array}$ & $\begin{array}{l}\text { Batton } \\
\text { Canister } \\
\text { OUT } \\
\text { (g) }\end{array}$ & Anst & $\begin{array}{c}\text { Total } \\
\text { Vessol } \\
\text { INI } \\
\text { (G) }\end{array}$ & $\begin{array}{l}\text { Tatal } \\
\text { Vessol } \\
\text { OUT } \\
\text { (\$!! }\end{array}$ & $\underset{\text { His: }}{\mathbf{A}}$ & $\begin{array}{l}\text { Vaker } \\
\text { Added } \\
\text { During } \\
\text { Testing }\end{array}$ \\
\hline & & & $\begin{array}{l}1324.0 \\
1320.5 \\
1328.4 \\
1928.0 \\
1329.1 \\
1329.5 \\
1324.3 \\
1324.4 \\
1324 \\
1324.1 \\
1324.4\end{array}$ & $\begin{array}{l}1320.6 \\
1328.7 \\
1328.8 \\
1328.8 \\
1324.9 \\
1329.8 \\
1320.8 \\
1324.3 \\
1324.7 \\
1329.5\end{array}$ & $\begin{array}{r}-4.0 \\
+4.7 \\
+4.6 \\
+9.6 \\
-9.5 \\
+8.3 \\
+8.3 \\
-8.7 \\
-4.4\end{array}$ & $\begin{array}{r}1.975 \\
8.975 \\
6.975 \\
6.975 \\
.975 \\
8.975 \\
6.075 \\
.975 \\
.975 \\
. .975\end{array}$ \\
\hline 4.0851 & & & $\begin{array}{l}1340.4 \\
1338.1 \\
1344.5 \\
1330.1 \\
1349.6 \\
1330.1 \\
1349.5 \\
1330.2 \\
1340.8\end{array}$ & $\begin{array}{l}1349.1 \\
2339.7 \\
1341.1 \\
1330.8 \\
1341.2 \\
1330.8 \\
1341.4 \\
1330.8\end{array}$ & $\begin{array}{r}+1.7 \\
-8.6 \\
+8.8 \\
+8.7 \\
+8.7 \\
+9.7 \\
+8.9 \\
+9.0\end{array}$ & $\begin{array}{r}0.976 \\
.976 \\
0.976 \\
6.976 \\
976 \\
.975 \\
.975 \\
.976\end{array}$ \\
\hline
\end{tabular}


The as-prepared glass specimens met the alpearance requirements given in procedure NNWSI-05-005. The as-cut sections were uniform in appearance and the sides were reflective and smooth. After testing the top and bottom surfaces were noticeably reacted as shown in Fig. 1. The regions of non-glass metal contact acted to accumulate reaction products. This majority of the reaction products were found surrounding the circumm ference of the holes in the waste form holder. This is where standing water was observed to exist in some of the tests upon opening the vessels. The regions of glass/metal contact showed little evidence of coverage by alteration products except in some localized cases where channels appeared to exist between the open areas. The extent of coverage by the rustcolored alteration products appeared to increase between the 13- and 26-week samples but was fairly constant thereafter.

The side surfaces of the glass retained their reflective appearance but were covered with random watermarks as shown in Fig. 2 of [BATES-3]. This appearance suggests that some water flowed over the sides but that the strong interactions present on the top and bottom surfaces did not occur. During the sampling and termination periods water was observed standing on the bottom canister section at the interface between the gliss

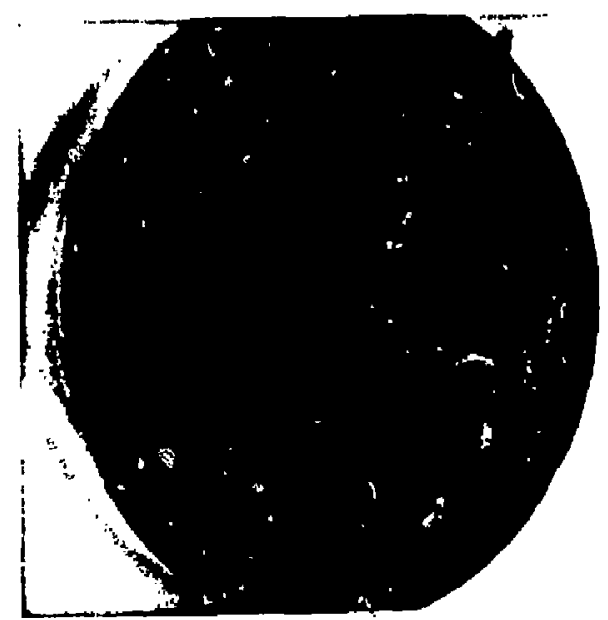

Fig. 1. Photograph of the Top Surface from Test $N 2 \# 7$ 
and the metal. Only for a few perlods was water observed on the top section of the waste form holder. It is believed that water that collects in this area evaporates during the cool down period before the vessels are opened. Condensed water is always observed on the inner sides and tops of the vessels.

The appearance of the top and bottom waste form holders ranged from a uniform deep blue coverage to a mix of blue and gold coverage. No measure of the extent of sensitization was made on the actual test specimens prior to testing. Such studies were done only after the test periods were complete (Section $C$ ).

After testing, the top and bottom holders were discolored in the glass contact region attaining a dark brown to rust-colored appearance. The interface where the glass contact ended was clearly marked by a buildup of precipitates. However, the extent of precipltate coverage did not visually increase with the length of testing period. This observation agrees with the measured weigint gains of the top and bottom canister sections which are constant throughout the 52-week test period.

\section{b. Solution Analysis}

The test solutions were analyzed either at the end of a test period or, for the continuous tests, during the sampling period. At the termination of a test, the waste package assemblage (WPA) was rinsed with $10 \mathrm{~mL}$ of high purity water, while for the continued tests, only the water collected in the bottom of the vessel was analyzed. Thus, the terminated tests contained a rinsed component that was not present in the continuous tests. A blank test was also run in the continuous mode. The purpose of this test was to evaluate whether any cross-contamination of racilonuclides had occurred during sample handling and to serve as a check of the EJ-13 water composition collected during a test period. The solutions were analyzed for components of the glass frit, the EJ-13 water, and for radionuclides.

The as-analyzed solution compositions are presented in Table 2. This table presents the total amount of each element detected $i: 1$ solution and the total volume of solution measured in the vessel upon sampling. The sampled volume differs from the total amount of liquid 


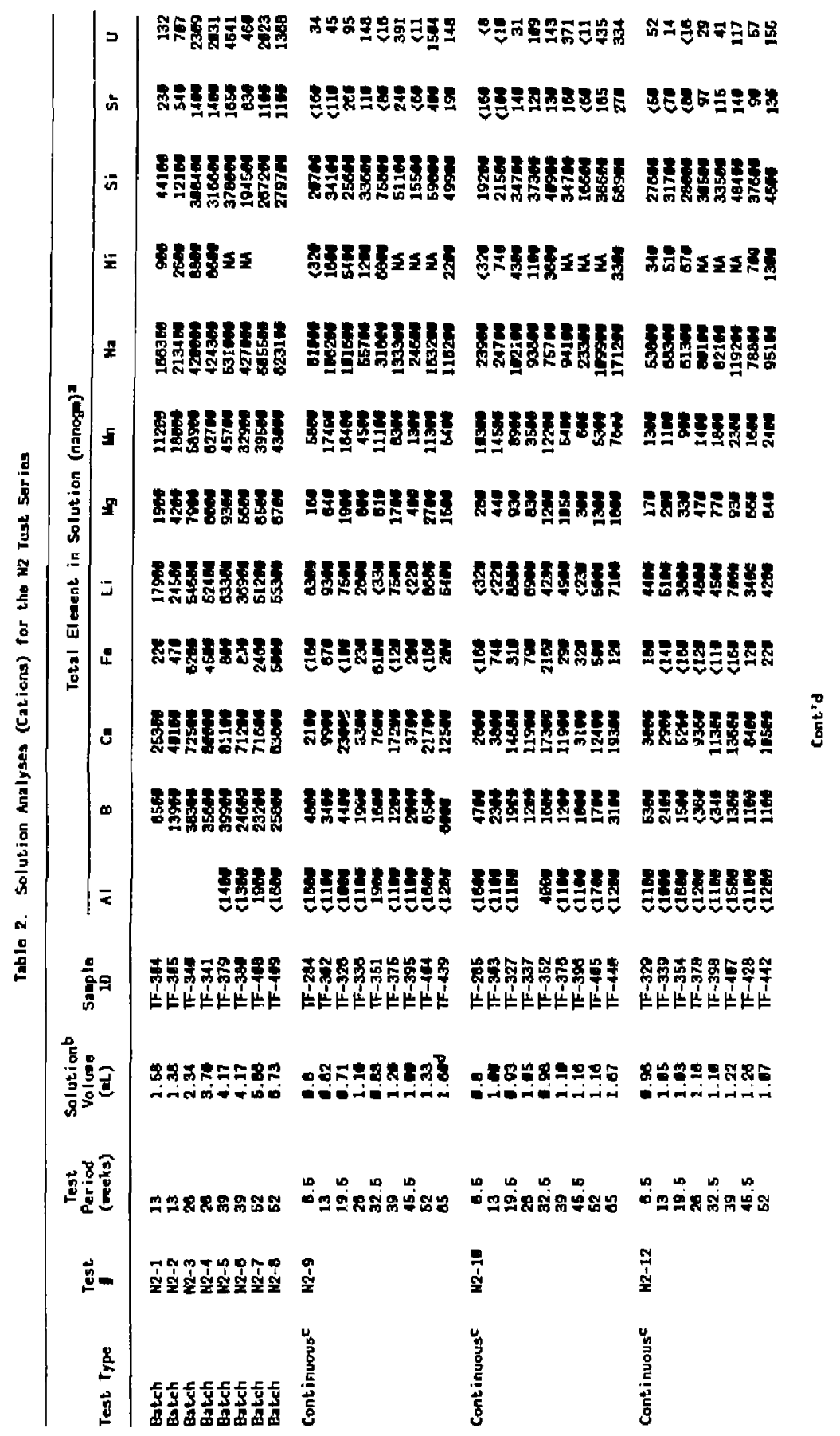




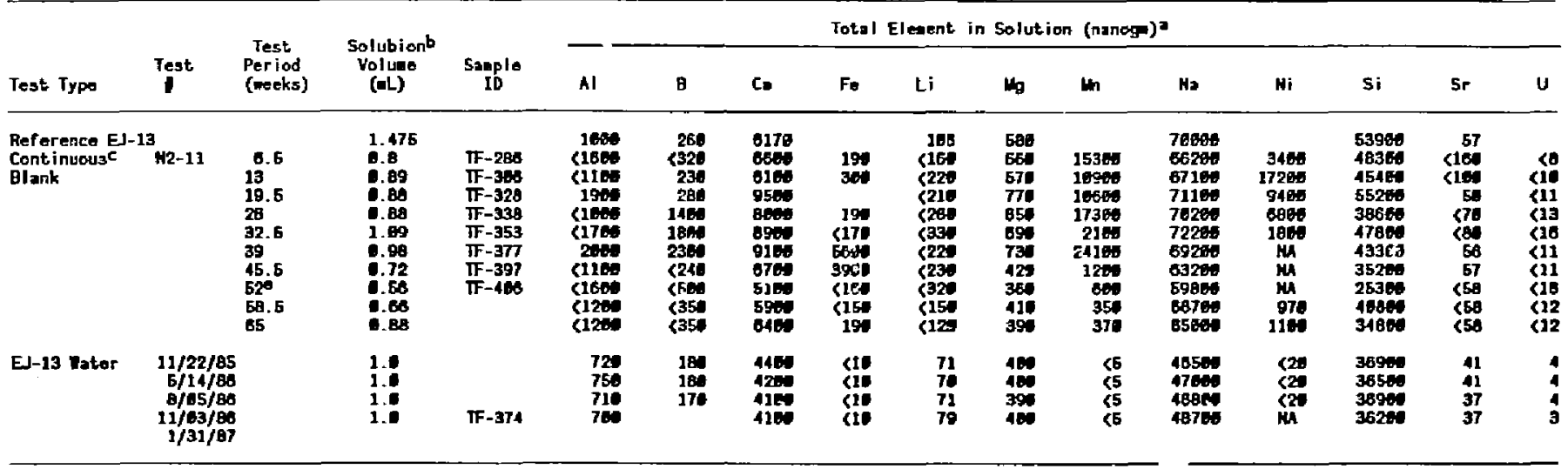

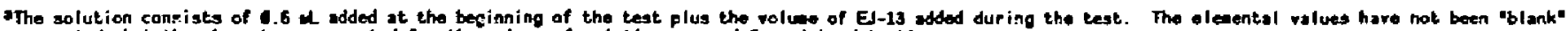
corrected, but they have been correctod for the valuab of solution reaved far siphs dolaction.

t.10 reported voluse is that reasining in the test vessel upon asapling or ternination. It is not the cotal solution added during testing eValues are for oach individual sanpling period.

dEstinated based on N2-10.

- Inlet line partially plugged thereby reducing the injected solution volua sligitly.

NA = not analyzed, olements for wich ne values are entered have been analyzed but not jot reported. 
injected during testing. This difference could be due to evaporative losses during handling or losses that occurred during injection. Analysis of the blank solutions suggest that most of the water loss occurred due to evaporation. This is because the amount of $\mathrm{Na}, \mathrm{Ca}$, and $\mathrm{Mg}$ detected in solution was near that predicted from the amount of EJ-13 water injected during a test period. For Si, the measured amount is usuaily less than predicted. The reason for this is not known, but the same observation was made during the $\mathrm{F}$ Test series [BATES-3].

The $C a$ and $B$ levels in the blank solutions were iarger than predicted from the input EJ-13 values for some sampling periods. This probably resulted from leaching of the gasket material, which during pretest experimentation was shown to release small amounts of these elements when soaked in water. At no time was any signiflcant amount of $237 \mathrm{~Np}$, ${ }^{239} \mathrm{Pu}$, or ${ }^{241} \mathrm{Am}$ detected in the blank solutions, indicating that a minimal risk of cross-contamination existed due to handling procedures.

The raw solution results can be used in two ways: (1) after correction for components present in the EJ-13 water the extent of glass reaction can be monitored, and (2) for the continuous tests an estimate of the composition of the water in contact with the waste package assemblage can be made. This water compositional information, in combination with the identification of alteration products formed on the test components, can be used to model the interactions that occurred during the test.

\section{Glass Reaction}

The extent of glass reaction is best measured by monitoring elements whose presence in solution can be associated mainly with the glass, as opposed to the EJ-13 water or the metal components of

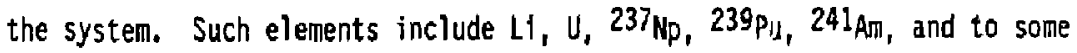
extent $B$. Boron is present in the starting EJ-13 water at an insignificant level, but as noted previously, some $B$ may be introduced into solution due to interaction with the gasket material. However, the data are presented assuming that most of the $B$ comes from the glass.

Blank corrected solution results are given in Table 3 (glass frit and EJ-13 components plus actinides). These results demonstrate several things: 
Tuble 3. Blank Corracted Solution Reaulte from the N2 Test Series:

\begin{tabular}{|c|c|c|c|c|c|c|c|c|c|c|c|c|}
\hline \multirow{2}{*}{ Tost } & \multirow{2}{*}{$\begin{array}{l}\text { Durøtion } \\
\text { (wook } \mathbf{x} \text { ) }\end{array}$} & \multirow[b]{2}{*}{$\mathbf{B}$} & \multicolumn{4}{|c|}{$9 m \times 10^{-9}$} & \multirow[b]{2}{*}{ si } & \multirow[b]{2}{*}{ sr } & \multirow[b]{2}{*}{$\mathbf{y}$} & \multirow{2}{*}{$\frac{g m \times 10^{-8}}{237 \mathrm{~Np}_{\mathrm{p}}}$} & \multirow{2}{*}{$\frac{9 \mathrm{~m} \times 10^{-10}}{238 \mathrm{Pu}}$} & \multirow{2}{*}{$\frac{9 m \times 10^{-11}}{241_{A m}}$} \\
\hline & & & $c$ & LI & M & No & & & & & & \\
\hline $\mathrm{H}_{2-1}$ & 13 & a1e0 & 14900 & 17796 & $\infty$ & 4806e & $(4706 \theta)$ & 130 & 120 & 6.2 & 22.7 & 6.8 \\
\hline $\mathrm{N} 2-2$ & 13 & 13400 & 28760 & 24360 & 3260 & 95100 & $(79000)$ & 440 & 700 & 13.9 & 40.4 & 14.8 \\
\hline $\mathrm{N}_{2}-\mathbf{3}$ & 26 & a7600 & 63860 & 64360 & 6100 & 2676ed & 144806 & 1260 & 2300 & 43.0 & 63.7 & 18.4 \\
\hline $\mathrm{N} 2-4$ & 30 & 34800 & 61300 & 521ea & 6260 & 211900 & 153006 & 1200 & 2000 & 02.0 & 73.0 & 22.9 \\
\hline N2- 5 & a9 & 38800 & EA196 & 6260d & 6000 & 224400 & 142000 & 1400 & 4600 & 42.3 & 64.2 & 16.0 \\
\hline N2-B & 39 & 23500 & 44260 & 30460 & 3260 & 120480 & (41ब6E) & 600 & 480 & 14.3 & 22.0 & 0.4 \\
\hline N2-7 & $\mathbf{E 2}$ & 21790 & 80300 & 50000 & 3200 & 204860 & $(41300)$ & 600 & 2000 & 10.4 & 37.7 & 16.4 \\
\hline N2-O & 62 & $243 e c$ & 28580 & 647E: & 2400 & 222400 & (28800) & e日0 & 1360 & 26.7 & 70.6 & 12.7 \\
\hline N2-O & $\begin{array}{l}13 \\
26 \\
39 \\
52 \\
65\end{array}$ & $\begin{array}{l}7760 \\
13406 \\
15700 \\
23766 \\
29260\end{array}$ & $\begin{array}{l}\text { (600) } \\
18209 \\
80409 \\
43300 \\
46400\end{array}$ & $\begin{array}{l}16400 \\
25560 \\
83109 \\
41700 \\
46906\end{array}$ & $\begin{array}{l}(460) \\
1160 \\
2300 \\
4200 \\
4760\end{array}$ & $\begin{array}{r}24806 \\
39706 \\
62406 \\
167609 \\
165700\end{array}$ & $\begin{array}{l}(54000) \\
(165360) \\
(88800) \\
(122460) \\
(163600)\end{array}$ & $\begin{array}{r}146 \\
406 \\
600 \\
960 \\
1040\end{array}$ & $\begin{array}{r}70 \\
300 \\
700 \\
2260 \\
2360\end{array}$ & $\begin{array}{r}3.9 \\
11.8 \\
16.5 \\
36.6 \\
33.3\end{array}$ & $\begin{array}{l}11.9 \\
17.8 \\
21.7 \\
26.4 \\
26.7\end{array}$ & $\begin{array}{l}3.1 \\
6.1\end{array}$ \\
\hline N2-10 & $\begin{array}{l}13 \\
26 \\
39 \\
52 \\
65\end{array}$ & $\begin{array}{r}6506 \\
19066 \\
11306 \\
13568 \\
16160\end{array}$ & $\begin{array}{c}(6000) \\
0000 \\
24600 \\
27600 \\
36500\end{array}$ & $\begin{array}{r}360 \\
15860 \\
24760 \\
20766 \\
36866\end{array}$ & $\begin{array}{l}(560) \\
160 \\
1260 \\
1800 \\
2460\end{array}$ & $\begin{array}{c}(93800) \\
(36506) \\
(2166) \\
(22460) \\
\text { abe00 }\end{array}$ & $\begin{array}{c}(60060) \\
(160606) \\
(146706) \\
(197160) \\
(231306)\end{array}$ & $\begin{array}{l}146 \\
290 \\
460 \\
670 \\
740\end{array}$ & $\begin{array}{r}10 \\
+46 \\
640 \\
1680 \\
1480\end{array}$ & $\begin{array}{l}0 \\
3.0 \\
6.3 \\
8.2 \\
8.2\end{array}$ & $\begin{array}{r}6 \\
6.0 \\
0.6 \\
11.6\end{array}$ & $\begin{array}{l}0 \\
2.6 \\
3.7 \\
4.6\end{array}$ \\
\hline$N 2-12$ & $\begin{array}{l}13 \\
28 \\
39 \\
52\end{array}$ & $\begin{array}{r}7200 \\
8506 \\
0800 \\
11390\end{array}$ & $\begin{array}{c}(0760) \\
(4600) \\
8009 \\
14300\end{array}$ & $\begin{array}{r}9400 \\
17706 \\
29060 \\
30360\end{array}$ & $\begin{array}{r}(806) \\
(1200) \\
(700) \\
(400)\end{array}$ & $\begin{array}{l}(30200) \\
(31200) \\
27709 \\
\text { so160 }\end{array}$ & $\begin{array}{l}\text { (60468) } \\
(16150 \theta) \\
(12030 \theta) \\
(16456 \theta)\end{array}$ & $\begin{array}{l}160 \\
240 \\
980 \\
480\end{array}$ & $\begin{array}{r}50 \\
280 \\
230 \\
430\end{array}$ & $\begin{array}{l}2.8 \\
4.5 \\
8.5\end{array}$ & $\begin{array}{l}22.4 \\
20.1 \\
36.9\end{array}$ & $\begin{array}{l}4.8 \\
6.9 \\
\text { e. }\end{array}$ \\
\hline
\end{tabular}


(1) All elements except S1 show a net release frum the glass. Silicon shows a net release in Tests $N 2 \# 3,4$, and 5 , but has a fairly constant net abstraction from solution in the remaining tests;

(2) An intercomparison of the batch test resuits indicates an apparent trend of increasing reaction through 26 weeks, followed by $19 t$ tle additional reaction thereafter (Fig. 2). This trend is borne out by a consistency in the release of all elements. The trend may be real, but more likely, when interpreted in conjunction with all the test data, is skewed by increased reaction in tests $N 2 \$ 3,4$, and 5 .

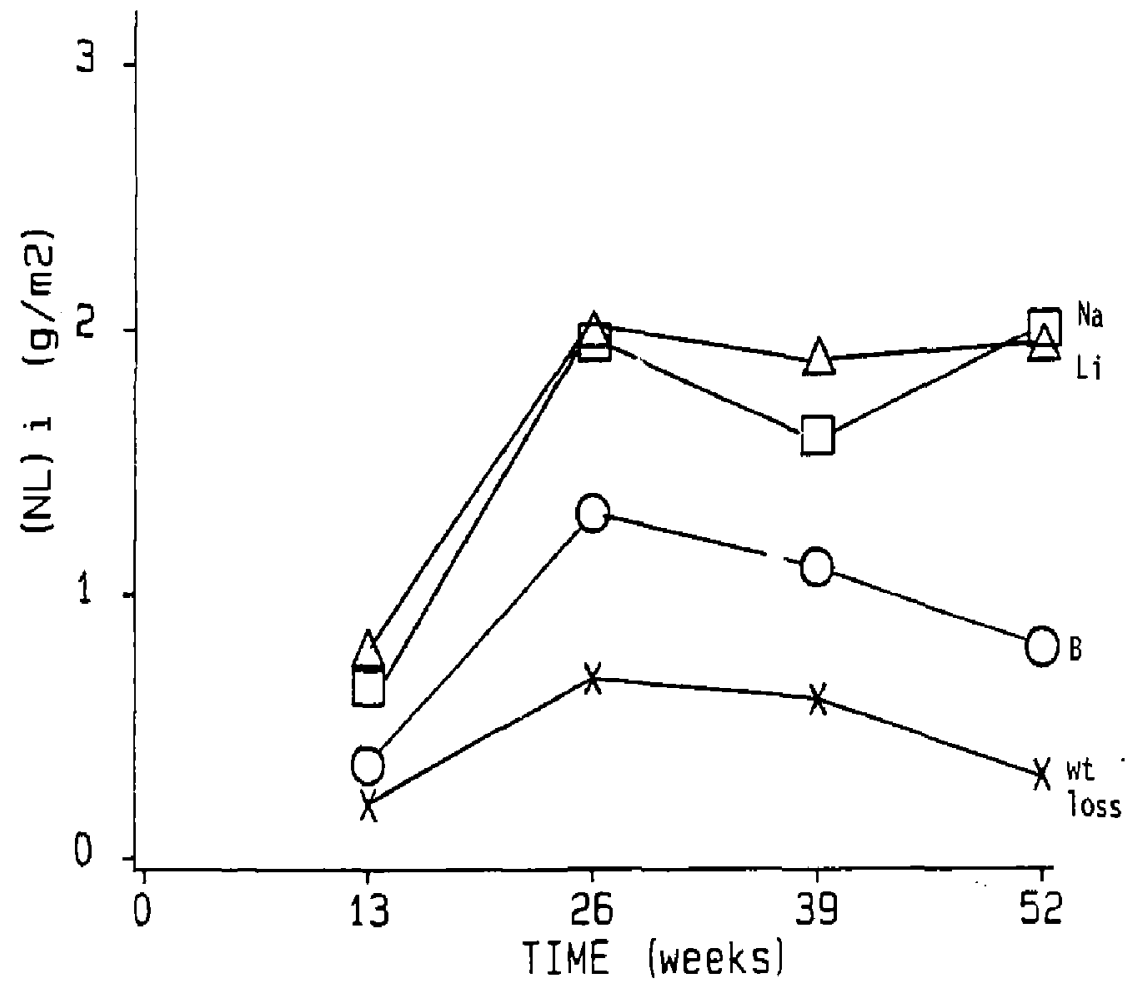

Fig. 2. (NL) $;$ from $N$ Batch Tests, $O=B, \Delta=L i, D=N a, X=w t$ loss 
(3) Release values (Table 4) were calculated normallzed to the total surface area of the glass and the mass fraction of each element in the glass. These standard (NL) i values indicate that the alkall elements $\mathrm{Li}$ and $\mathrm{Na}$ are released from the glass at nearly equivalent rates which are larger than that calculated for $B$ or the actinide elements. Note the normalized release of $B$ is nearly equivalent to that of $\mathrm{Np}$ which is greater than $U$ which is greater than Pu and Am. The plotted releases (Fig. 2) are calculated based on the measured amount of each element released from the waste package assemblage after rinsing. However, if the amount of $P u_{,} A m_{0}$ and $U$ remaining with the metal components of the WPA is measured vla complete stripping (Table 4) of the metal, and $i t$ is assumed that the release of these elements is associated mainly with the glass that is in contact with metal, then modified (NL) Pu, Am, U values can be calculated, which are much nearer to the values of $B$ and $N$. In the continuous tests, where the components have not been rinsed before the solution is analyzed, several elements, including $\mathrm{Ca}, \mathrm{Mg}, \mathrm{Na}$, and $\mathrm{Si}$, are depleted in the analyzed solution compared to the starting EJ-13 water. Normalized release values for $L^{4}$ in the continuous tests are plotted in Fig. 3. While these values will be slightly lower than the batch tests due to the rinse component, it is seen that there is continuous release from the glass through the 65 -week time period. For $L i$, the elemeil that apparently is least affected by interaction with test components, the normalized release values after $\$ 2$ weeks of testing are highlighted in table 5. The values for the continuous tests have been calculated assuming that 7000 ngm of $L 1$ will be rinsed from the waste package assemblage to make the continuous values comparable with the batch tests. The $7000 \mathrm{ngm}$ value was taken from measured differences between batch and continuous tests in the F-1 Test series [BATES-3]. The consistency of these values at 52 weeks, combined with the continued increasing reaction trend observed in the continuous tests, suggests that the plateau in reaction progress seen by comparing batch test results is due to a physical effect that accelerated the reaction in tests $N 2,3,4$, and 5 compared with the other tests. This possibility will be discussed later. 
Tablo 4. Normalized Release of Elomente from the cless in the N2 Tosts

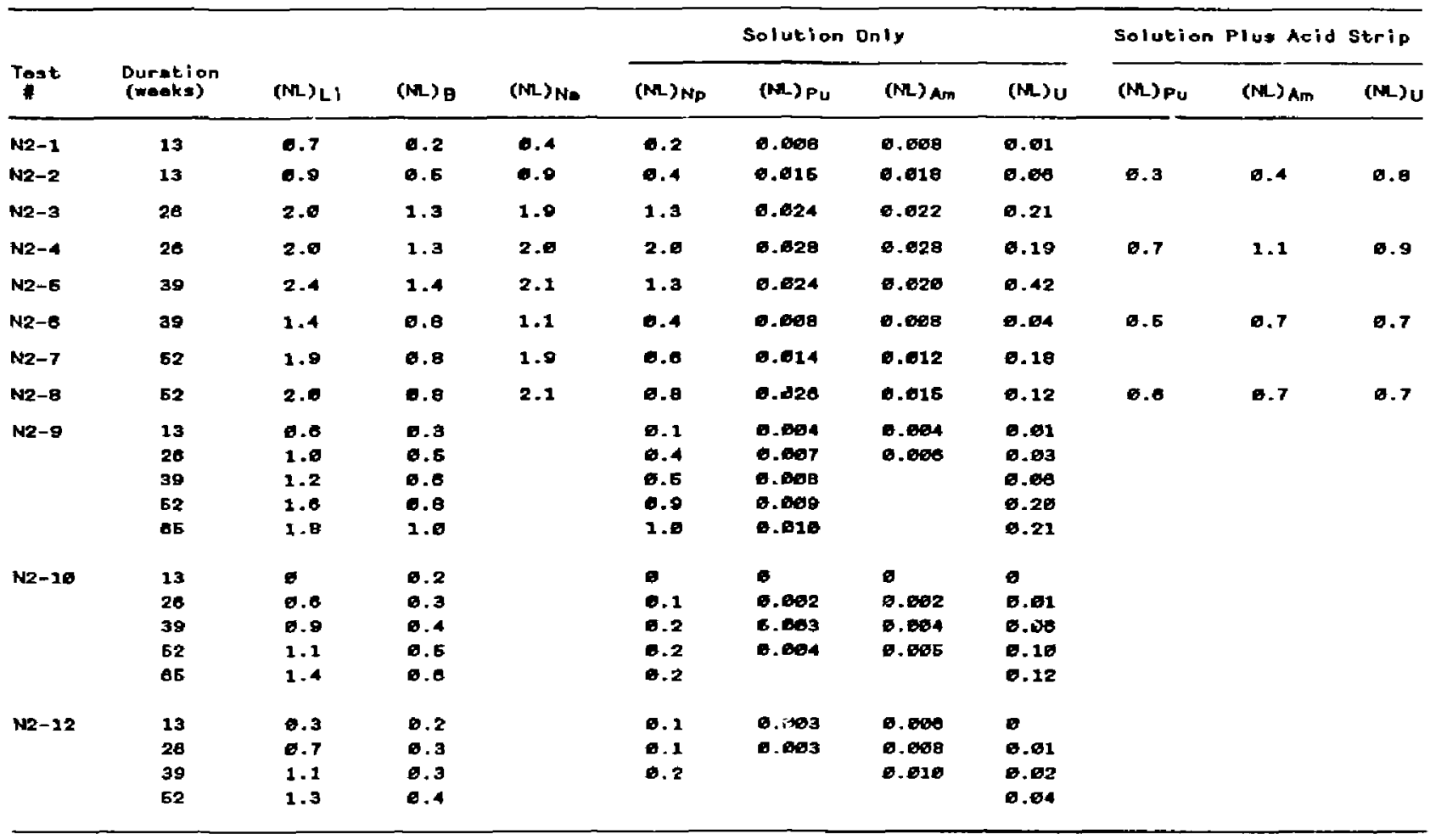




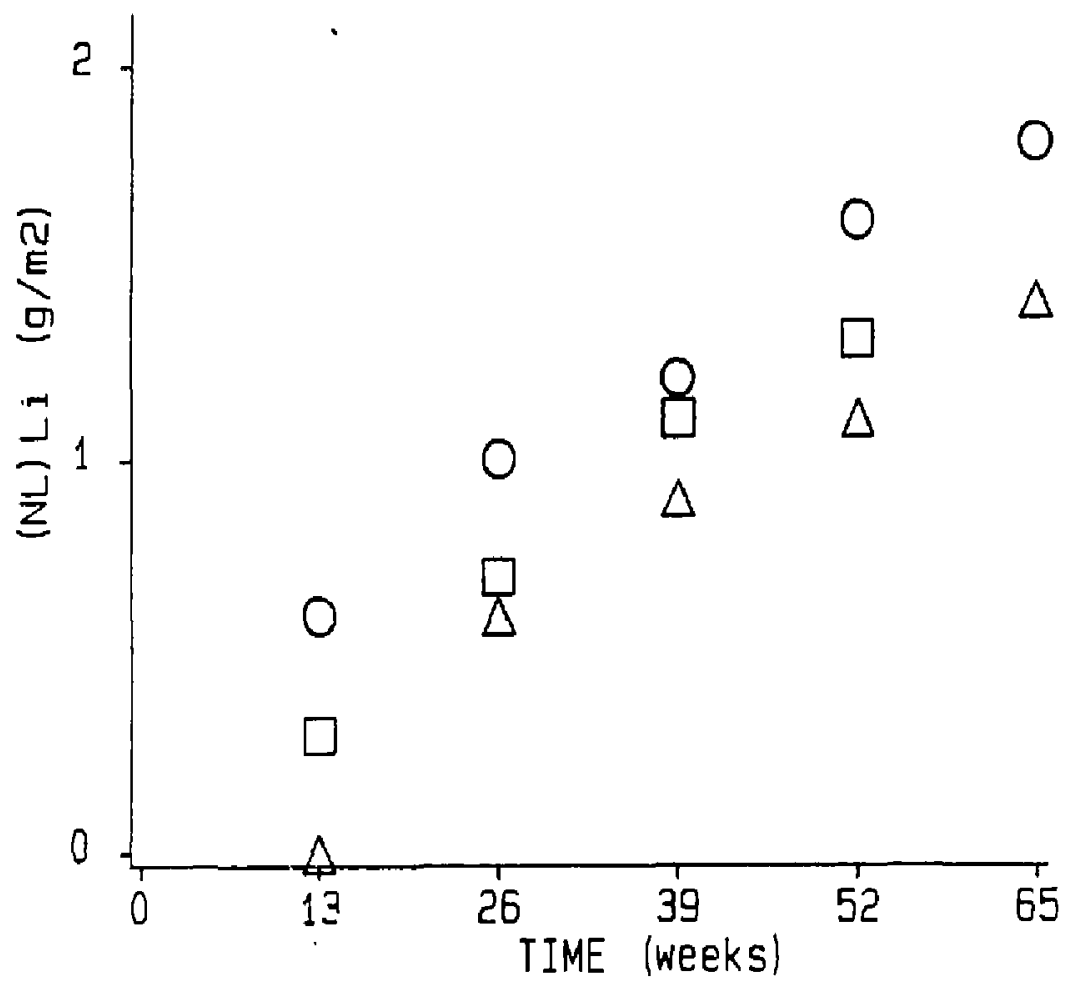

Fig. 3. (NL) LI Continuous Tests, $O=N 2 \# 9, \Delta=N 2 \$ 10, \square=N 2 \# 12$

Table 5. Nomalized Lithium Release through 52 Weeks of Testing

\begin{tabular}{lc} 
Test $\#$ & $(\mathrm{NL}) \mathrm{Li},\left(\mathrm{g} / \mathrm{m}^{2}\right)$ \\
\hline N2 $\# 7$ & 1.9 \\
N2 $\$ 8$ & 2.0 \\
N2 $\# 9$ & 1.8 \\
N2 $\$ 10$ & 1.4 \\
N2 $\# 12$ & 1.6 \\
\hline
\end{tabular}




\section{Solution Composition}

The composition of the solution that was in contact with the waste package assemblage can be est/mated from the results of the continuous tests. This solution composition is important because it is the interaction between the leachate and the waste package components that results in the formation of alteration products that are more stable than the glass and may over the course of the repository time period influence which reactions will occur. In the continuous tests the volume of water collected in the test vessel after WPA contact was measured and its composition was determined. While the process by which the water was removed from the WPA was a combination of evaporation and dripping, the collected water should be somewhat representative of the water as it reacted with the WPA. Indeed, it is unlikely that the composition of the water that collected on the top and bottom sections of the waste package assemblage had exactly the same composition due to the flow characteristics of the test. Regardless, the elemental concentrations of the leachates in the continuous tests are given in Table 6. These values have been calculated by assuming that all the water injected during a test period has contacted the WPA, reacted, and was released and collected in the test vessel. The solution collected in the test vessels consisted of injected EJ-13 water that had reacted with the waste package assemblage, plus $0.5 \mathrm{~mL}$ of $\mathrm{EJ}-13$ water that was placed in the bottom of the test vessel before the test began and at each sampling period. The eleinental concentrations were determined by subtracting the volume and compositional effect of the EJ-13 water that was added initially to the bottom of the test vessels before the test and at each sampling period, from the ailalyzed results, and then dividing the remaining elemental values by the volume of injected liquid. Values have been combined for two 6.5-week pertods because of inconsistent releases from the waste package assemblage for one 6.5-week period. For example, in the N2-10 test no liquid dripped from the waste package assemblage during the first two test periods (ref. Li and actinide solution values), although the waste package assemblage was visually reacted to the same degree as the other tests. These solution compositions will be used with information obtained during the analyses of the test components to provide input to the modeling effort. 
Table 6. Composition of Leachates Collected during the Continuous N2 Tests

\begin{tabular}{|c|c|c|c|c|c|c|c|c|c|}
\hline \multirow{2}{*}{ Test \# } & \multirow{2}{*}{$\begin{array}{l}\text { Sampling } \\
\text { Period } \\
\text { (weeks) }\end{array}$} & \multicolumn{8}{|c|}{ Solution Composition (ppm) } \\
\hline & & B & $\mathrm{Ca}$ & L1 & $\mathrm{Mg}$ & $\mathrm{Na}$ & $\$ 1$ & $\mathrm{Sr}$ & U \\
\hline Initial & $E J-13$ & 0.2 & 4.5 & 0.1 & 0.4 & 48 & 37 & 0.04 & 0.004 \\
\hline N2-9 & $\begin{array}{l}13 \\
26 \\
39 \\
52 \\
65\end{array}$ & $\begin{array}{l}4.1 \\
3.1 \\
1.3 \\
4.2 \\
3.0\end{array}$ & $\begin{array}{r}4.0 \\
13.9 \\
10.6 \\
10.8 \\
5.3\end{array}$ & $\begin{array}{l}8.0 \\
5.2 \\
4.0 \\
4.5 \\
2.8\end{array}$ & $\begin{array}{l}0.2 \\
1.2 \\
1.0 \\
1.4 \\
0.7\end{array}$ & $\begin{array}{l}61 \\
56 \\
60 \\
71 \\
47\end{array}$ & $\begin{array}{l}9.0 \\
11 \\
46 \\
20 \\
16\end{array}$ & $\begin{array}{l}0.1 \\
0.2 \\
0.1 \\
0.2 \\
0.1\end{array}$ & $\begin{array}{l}0.04 \\
0.12 \\
0.21 \\
0.77 \\
0.08\end{array}$ \\
\hline$N 2-10$ & $\begin{array}{l}13 \\
26 \\
39 \\
52 \\
65\end{array}$ & $\begin{array}{l}3.5 \\
1.5 \\
1.3 \\
1.3 \\
1.5\end{array}$ & $\begin{array}{r}1.2 \\
11.4 \\
12.8 \\
5.8 \\
8.8\end{array}$ & $\begin{array}{l}0.2 \\
8.0 \\
4.6 \\
2.6 \\
3.6\end{array}$ & $\begin{array}{l}0.2 \\
0.7 \\
0.9 \\
0.6 \\
0.8\end{array}$ & $\begin{array}{l}5.3 \\
76 \\
62 \\
38 \\
75\end{array}$ & $\begin{array}{l}1.8 \\
18 \\
20 \\
8.2 \\
20\end{array}$ & $\begin{array}{l}0.1 \\
0.1 \\
0.1 \\
0.1 \\
0.1\end{array}$ & $\begin{array}{l}0 \\
0.07 \\
0.26 \\
0.22 \\
0.17\end{array}$ \\
\hline N2-11 & $\begin{array}{l}13 \\
26 \\
39 \\
52\end{array}$ & $\begin{array}{l}3.9 \\
0.9 \\
0.8 \\
1.0\end{array}$ & $\begin{array}{r}0.8 \\
5.3 \\
10.7 \\
7.5\end{array}$ & $\begin{array}{l}4.8 \\
4.3 \\
5.8 \\
3.9\end{array}$ & $\begin{array}{l}0 \\
0.2 \\
0.7 \\
0.6\end{array}$ & $\begin{array}{l}33 \\
48 \\
79 \\
64\end{array}$ & $\begin{array}{l}11 \\
11 \\
23 \\
24\end{array}$ & $\begin{array}{l}0 \\
0.1 \\
0.1 \\
0.1\end{array}$ & $\begin{array}{l}0.03 \\
0.02 \\
0.08 \\
0.11\end{array}$ \\
\hline
\end{tabular}

\section{c. Analysis of Test Components}

To characterize the interactions that have occurred during testing, the components of the test have been examined using SEM/EDS and XRD. The purpose of such characterization is (1) in combination with the solution results, to provide a description of the reaction progress; and (2) to catalog and, if possible, identify alteration products that form during the course of the reaction. Both of these issues need to be addressed to provide input to be used in projecting the performance of the waste form to repository time frame.

At the end of a test period, the test components were separately rinsed with high-purlty water and placed in a dust-free environment to dry. The weight change for each component was determined and then 
components from selected tests ( $N 2 \neq 5,4,6$, and 8) were analyzed. The components from the remaining tests (N2 \#s $1,3,5$, and 7 ) were maintained in storage to be analyzed using additional techniques as they become avallable. The methods and rationale used to perform and interpret the SEM/EDS analyses have been described previously [BATES-3]. The specimens were photographed using a low resolution optical microscope in order to map the surface and to identify regions of interest. The glass samples were then examined using SEM/EOS to obtain a qualitative description of the phase present. Micrographs and EOS spectra were taken extensively. After removal from the SEM, phases amenable for XRD study, e.g., unique composition, crystalline structure, large enough, were picked froin the surface and analyzed.

SEM/EOS can be used to provide a description of the phases and alteration products, but cannot be used for absolute identification. Additionally, after exposure to the coating process and vacuum conditions of the SEM, the sample may be altered to make examination by other spectroscopic methods such as infrared or Raman spectroscopy itfficult, if not misleading. For this reason not all of the samples were imediately analyzed.

The canister components were also photographed and examined via SEM/EDS and XRD. They were then acid-stripped to remove all residual radioactivity, mounted in epoxy, polished, and subjected to an oxalic acld etch process to measure the extent of sensitization that occurred during the heat treatment step.

These component analyses have resulted in an extensive collection of micrographs and spectra. In the following discussions, only a representative selection of these analyses will be presented to provide a description of the reaction process. A complete compllation of the data set is avallable for review at ANL.

\section{i. Glass}

The weight change measurements for the glass samples are given in Table 1. All samples lost weight, al though, as shown in Fig. 1 the glass samples were covered extensively with reaction products. The weight loss normalized to the surface arez of the specimens, (NL) wt, closely followed the reactive trend observed for the glass as determined by 
the solution results (see Fig. 2), e.g., those tests in which the largest weight loss was observed also had a concomitant release of glass components to solution. The $(\mathrm{NL})_{\mathrm{Wt}}$ in all tests was about $50 \%$ the value for $(\mathrm{NL})_{\mathrm{B}}$. All of the glass surfaces (top and bottom) had the general appearance sıown in Fig. 1. The top surfaces gave the appearance of being slightly more reacted than the bottom mainly due to an apparently greater coverage of the rust-colored precipitates and the lighter appearance of the glass where there was contact between glass and metal. This appearance of reduced reaction I1kely resulted because the interface between the glass and the metal was better maintained on the bottom section due to the weight of the glass, while a looser interface existed at the top. However, the nature of the reaction products was the same for both the top and bottom sections.

The greatest extent of precipitate butldup occurred around the circumference of the holes where the metal contacted the glass. Precipitate butldup typical of that located in the non-metal contact regions of the glass is shown in Fig. 4. Such regions are where standing water collected during the test and the bulk of the precipitates were composed of Fe or Fe/N1/Cr/Mn combined with St and a smaller amount of $\mathrm{Al}$. The compositions of these alteration products as determined by EDS (Figs. 5 and 6) were not unique, varying continuously over a range between pure Fe and Fe-enriched Si/AT. XRD of the main regions of precipitate buildup indicated both $a-\mathrm{Fe}_{2} \mathrm{O}_{3}$ and $\mathrm{FeO}(\mathrm{OH})$ to be present; however, no pattern was obtained that could be attributed to the Si/Al phase.

In addition to these prominent regions of phase buildup, other alteration products were located in a random fashion over the glass surface. In several instances, only a limited number of each phase was found on the surface. In many cases, the phases were of micron size and were too small for XRO analysis, and only SEM/EDS information has been collected to date. Several representative micrographs of alteration phases are shown in Figs. 5 and 6. 


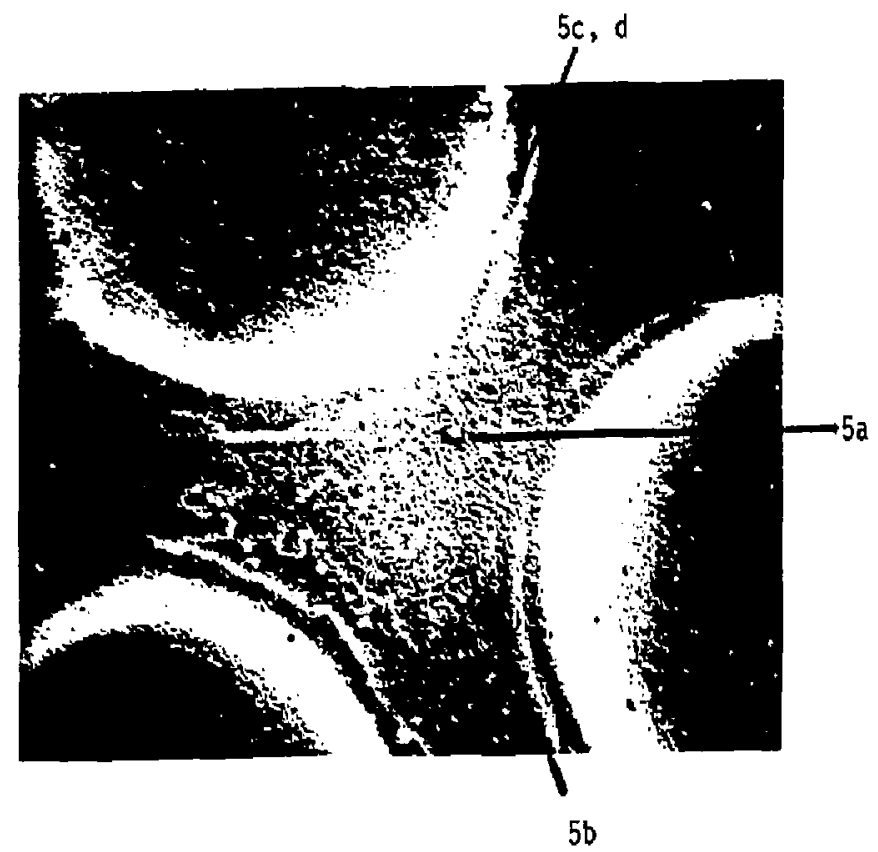

Fig. 4. Secondary Electron Photomicrograph of the Bottom Gilass Surface from Test $N 2$ \#8. Magnification $19 x$. 

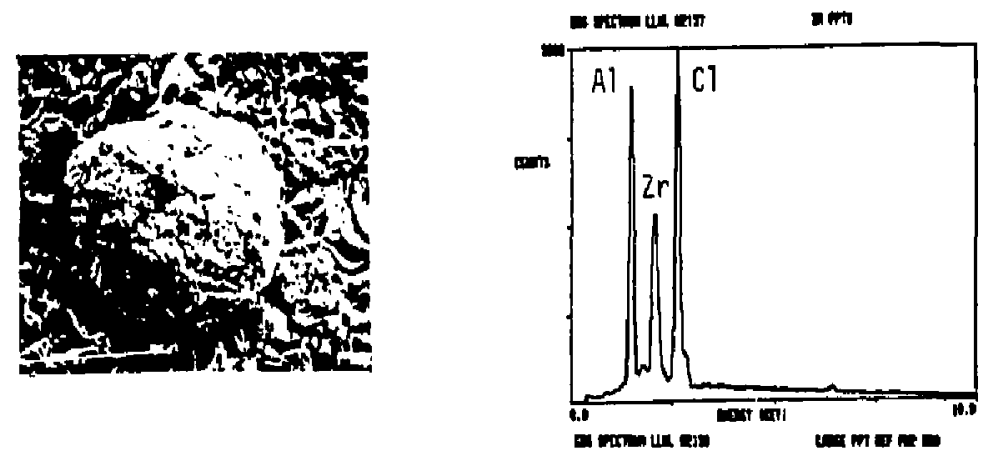

(a)
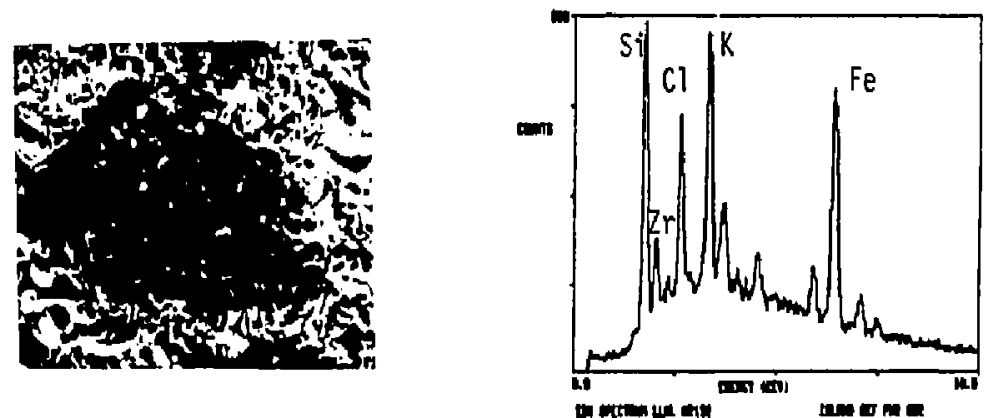

(b)

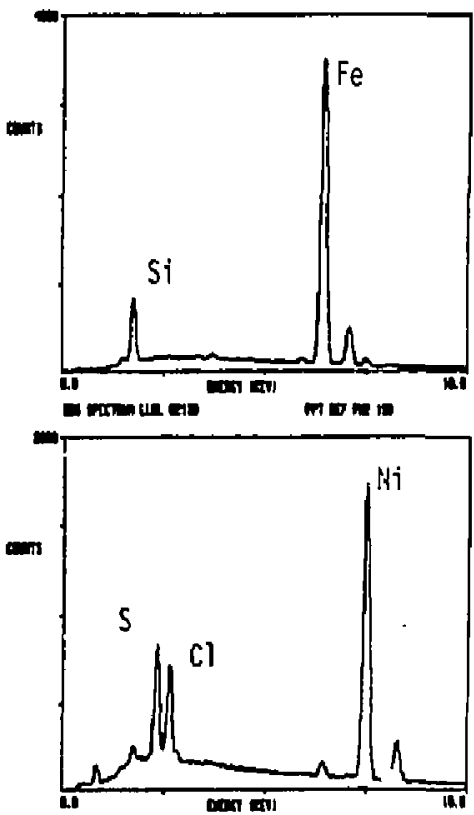

(c)

(d)

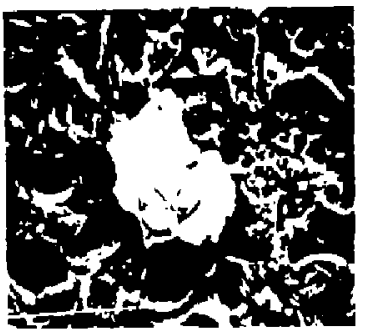

Fig. 5. Photomicrographs and EDS Spectra of Alteration Products Shown in (a) the Center of Fig. 4, Magnification 700x; (b) the Lower Center of Fig. 4, Magnification 350x; (c) the Upper Center of Fig. 4, Magnification 1500x; and (d) the Upper Center of Fig. 4, Magnification $1500 x$. 

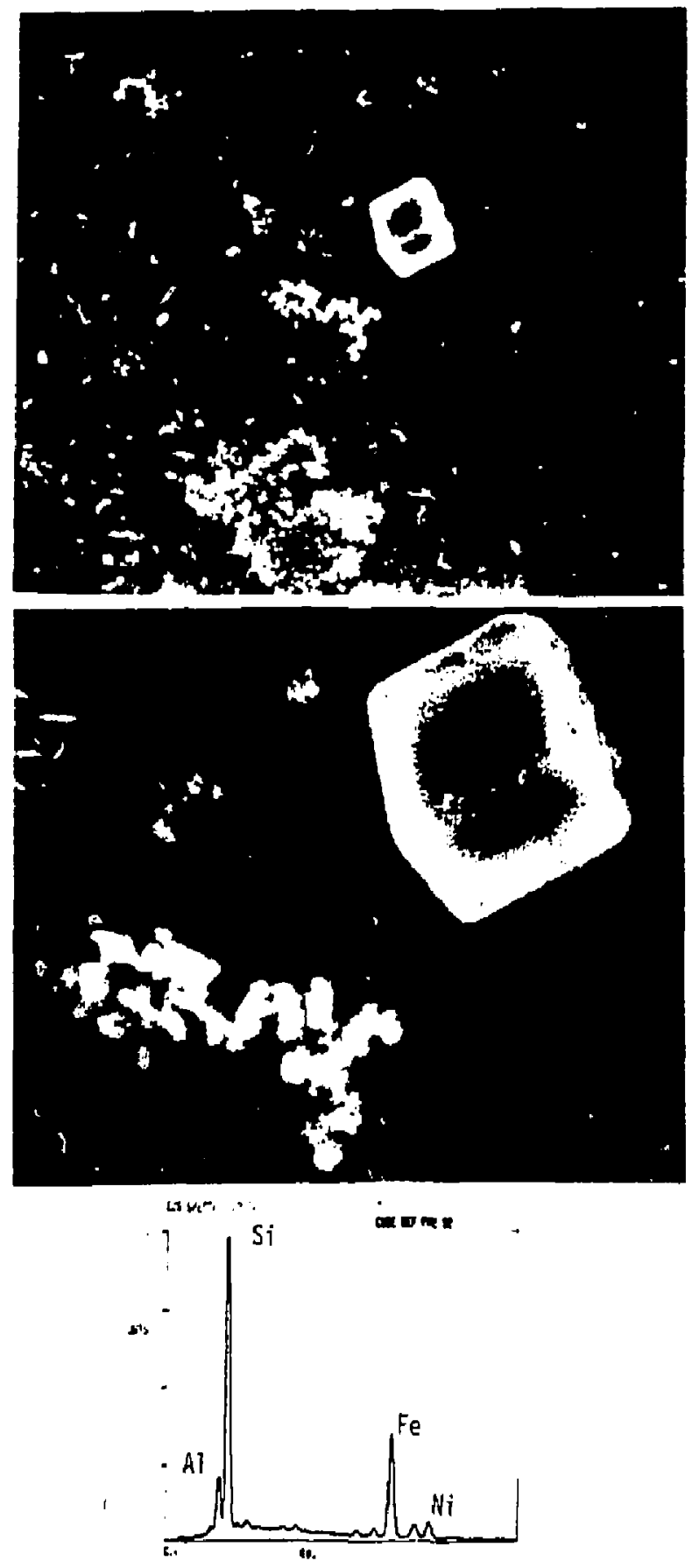

Fig. 6. Photomicrograph and EDS Spectra of Alteration Products that Formed on the Top Glass Surface from Test $12 \$ 6$, Magnification 3000x. 


\section{Canister Sections}

As with the glass, the greatest bulldup of reaction products was found in regions where standing water could accumulate. Such regions existed around the rims of the punched holes and at the edge of the glass/metal interface. Selected regions of reaction product butldup are shown in Fig. 7. Iron oxides and hydroxides together with an Al/Si mat (not shown) were the prominent reaction products. EDS spectra of localized reaction products are shown in Fig. 8.

After the cantster sections were examined usirg SEM/EDS, they were acid stripped, mounted in epoxy, and subjected to an oxalic acid etch to determine the extent of sensitization for samples $N 2$ \#s $2,4,6$, and 8 , a reference sample, and the canister sections from the analogue experiment. Typical micrographs of the metal sections are shown in Fig. 9. Different degrees of sensitization were observed for different groups of samples. The entire surface of the analogue canisters showed only random pittinn: that was not associated with grain boundaries and represented nonsensitized metal (Fig. 9c). Samples from test $N 2: 6$, and $N 2$ B showed extensive sensitization of the bulk metal, but significantly less sensitization near the flat surfaces of the canister that were in contact with the glass (Fig. 9b). The gap where there was incomplete sensitization ranges between 30 and $40 \mu m$ for these samples. Samples from tests $N 2 \# 2$ and N2 \#4 aiso showed complete sensitization of the bulk, but showed a non-sensitized gap of only 10-15 $\mu \mathrm{m}(\mathrm{F} / \mathrm{g}, 9 \mathrm{a})$. Note that the gap only existed on the surfaces of the steel that had been subjected to some processing (cold working) during manufacturing which was not altered during coniponent preparation procedures. Only where the edges of the canister sections had been machined did the sensitization extend to the surface of the metal.

\section{d. Discussion}

A complete discussion of the results is presented in the topical report "Application of the ANWSI Unsaturated Test Procedure to Actinide Doped SRL 165 Type Glass." A synopsis of the findings are: 


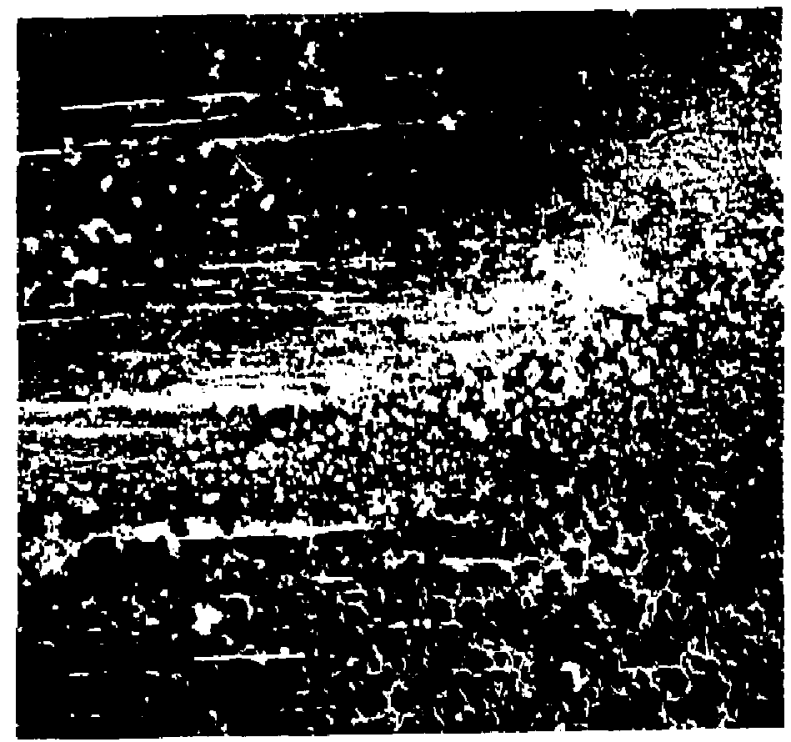

(a)

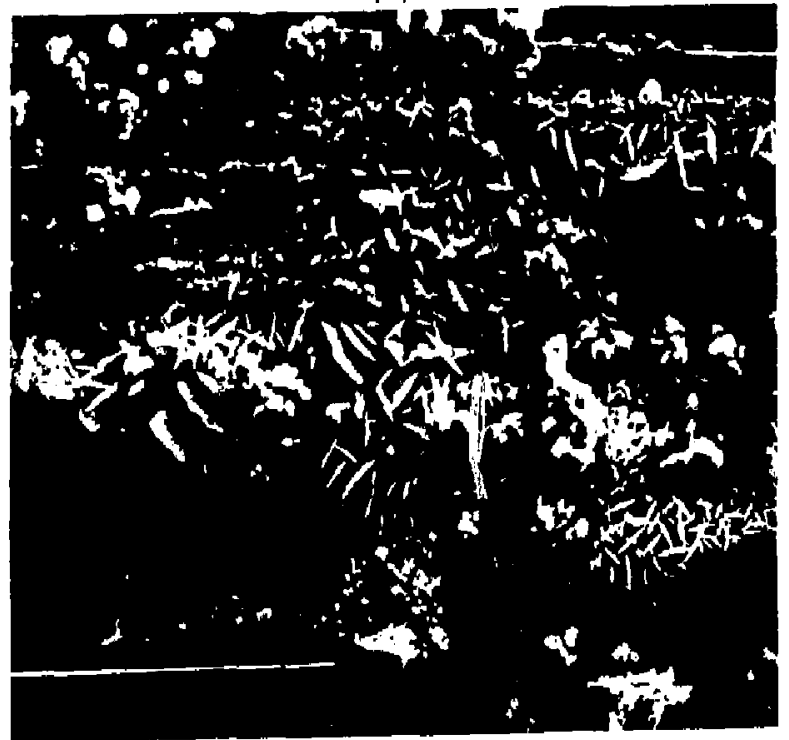

(b)

Fig. 7. (a) Buildup of Precipitates at the Interface Around the Circumference of the Punched Holes in the Stainless Steel, Bottom Canister, Test N2 $\# 2$, Magnification 250x, Marker $=55 \mu \mathrm{m}$.

(b) Higher Magnification Micrograph (1200x) of the Central Region of Fig. 4a, Marker $=5 \mu \mathrm{m}$.

Both micrographs are SEM images using secondary electrons. 


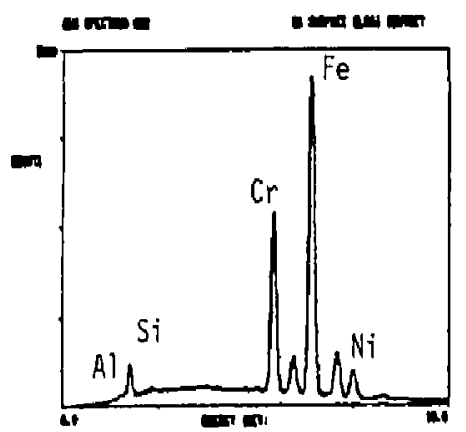

(a)

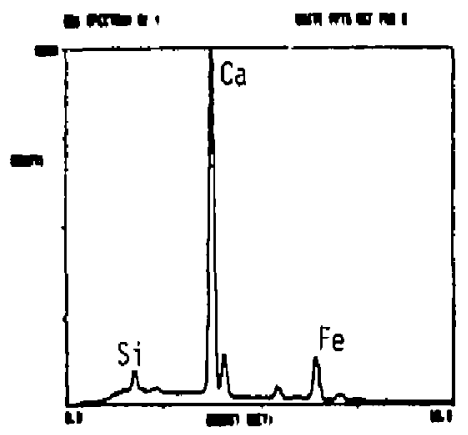

(c)

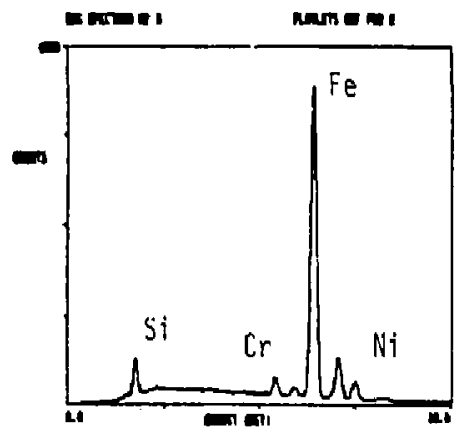

(b)

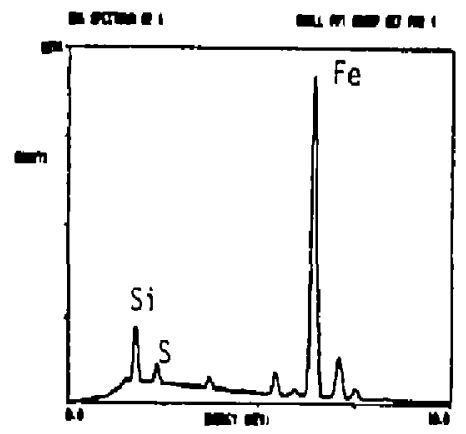

(a)

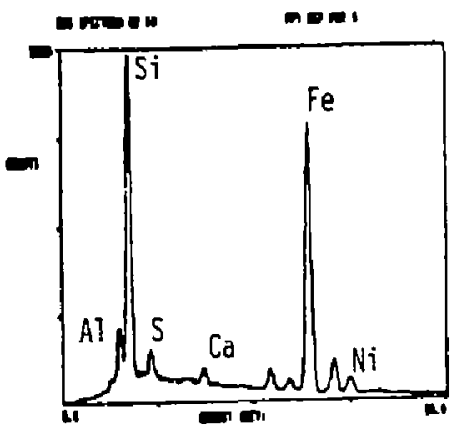

(e)

Fig. 8. EDS Spectra of Selected Areas Shown in Fig. 7. The areas of the sample which correspond to the spectra are shown in Fig. 7. 


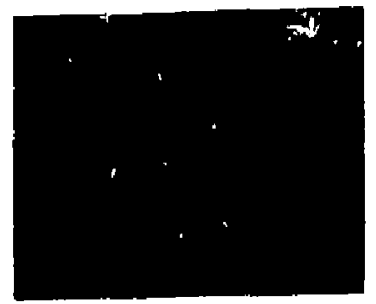

(a)

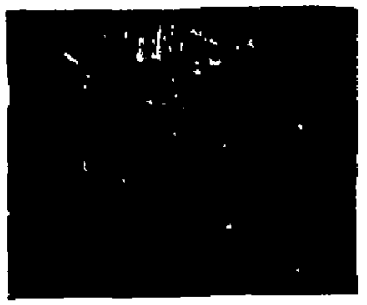

(b)

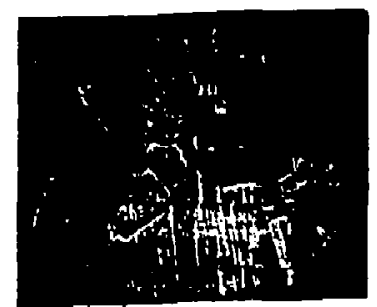

(c)

Fig. 9. Micrographs of Pollshed Cross-Sections of Etched Stainless Steel Waste form Holders for the N2 Test. (a) N2 \#4 bottom canister; (b) N2 \#8 top canister; (c) analog III \#1, top canister. Al1 micrographs were collected using backscattered electron imaging and the magnification is $375 x$. 
(1) The extent of glass reaction is dependent mainly on the interaction that occurs between the glass, the metal, and standing water. In all tests heat treatment of the metal resulted in the extensive formation of tron oxide/hydroxide and alumina sillicate reaction products. For those tests which had the greatest degree of sensitization, the extent of glass reaction was greatest;

(2) The (NL) of the alkali metals was the largest of the elements measured and was not much different from that observed in the F-1 series of tests (only localized heat treatment near the welded pins existed in these tests) [BATES-3]. However, the release of elements released by matrix breakdown of the glass, e.g., B, actinides, was comparatively greater in the $\mathrm{N}-2$ tests because the matrix breakdown promoted by the presensitized metal was more widespread in the $\mathrm{N} 2$ test serles than in the $\mathrm{F}-1$ series where only the weld-affected regions showed enhanced reaction; and

(3) The release of Pu and Am from the glass was controlled mainly by breakdown of the glass matrix in the areas where glass metal contact occurred. A large fraction of the actinides remained with the metal surfaces and could only be removed by acid stripping. The amount of Pu and Am actually released, including a water rinse, resulted in $(\mathrm{NL})_{\mathrm{Am}, \mathrm{Pu}}$ of $\left\langle 0.01 \mathrm{~g} / \mathrm{m}^{2}\right.$, and that for the testing periods to date, no saturation of the capacity of the metal to effectively remove actinides from solution was observed.

\section{Unsaturated Test $\mathrm{N}-3$}

The N3 Unsaturated Test will be done using ATM-10 glass (simulated West Valley glass containing actinfdes plus ${ }^{99} \mathrm{TC}$ ) that was received from the HCC. Preparations and inspections of the glass and test components have been completed, and the test was started 7/6/87 according to the matrix shown in Table ?. 
Table 7. Tost Hatrix and Couponent Toights for H3 Test Series

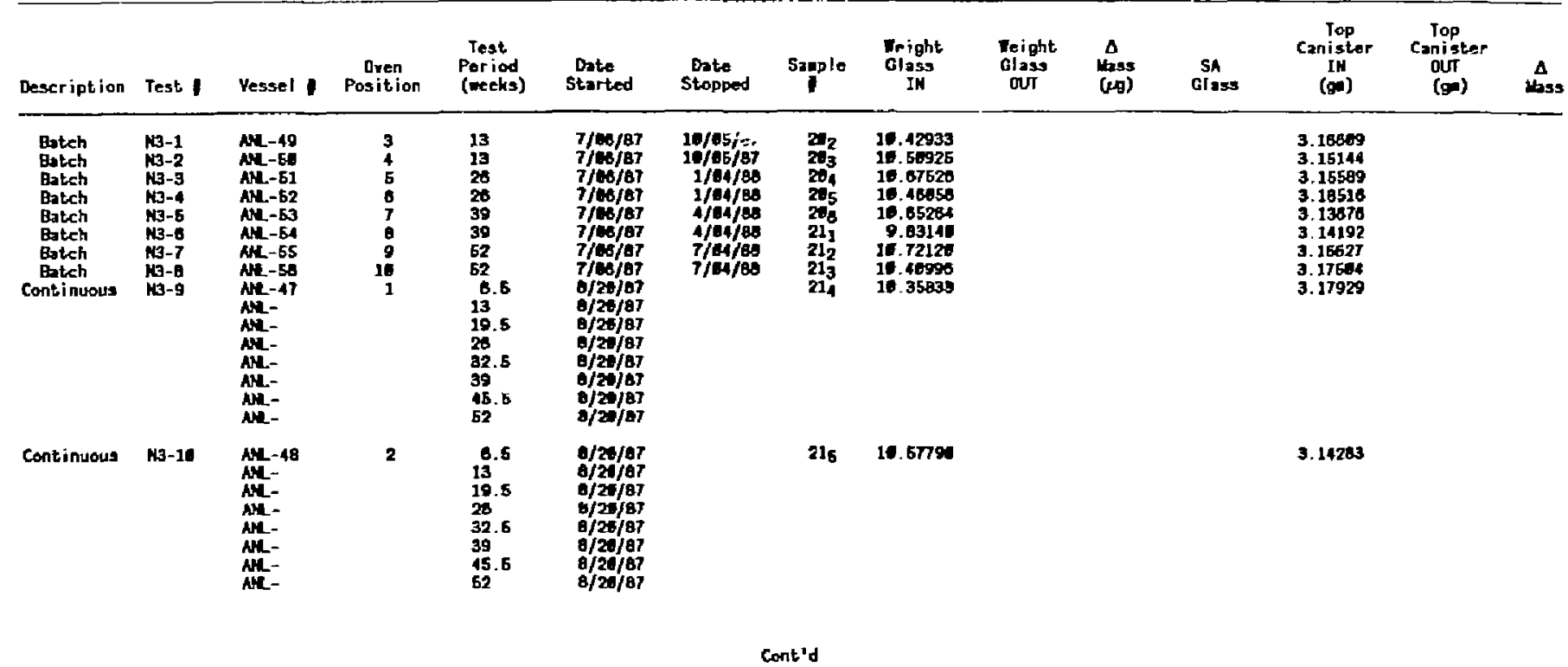


Table $T$ (Cont'd)

\begin{tabular}{|c|c|c|c|c|c|c|}
\hline $\begin{array}{l}\text { Botton } \\
\text { Canister } \\
\text { IH } \\
\text { (g) }\end{array}$ & $\begin{array}{l}\text { Bottoa } \\
\text { Canister } \\
\text { DUT } \\
\text { (g) }\end{array}$ & $\underset{\text { Hass }}{\Delta}$ & $\begin{array}{c}\text { Total } \\
\text { Vessel } \\
\text { IN } \\
(g)\end{array}$ & $\begin{array}{l}\text { Total } \\
\text { Vessel } \\
\text { OUT } \\
\text { (g) }\end{array}$ & $\underset{\text { Lass }}{\Delta}$ & $\begin{array}{l}\text { Water } \\
\text { Added } \\
\text { During } \\
\text { Test ing }\end{array}$ \\
\hline \multicolumn{7}{|l|}{4.12109} \\
\hline \multicolumn{7}{|l|}{4.12482} \\
\hline \multicolumn{7}{|l|}{ 4.166er } \\
\hline \multicolumn{7}{|l|}{ 4.08635 } \\
\hline \multicolumn{7}{|l|}{4.16659} \\
\hline \multicolumn{7}{|l|}{4.11724} \\
\hline \multicolumn{7}{|l|}{4.11810} \\
\hline \multicolumn{7}{|l|}{ 4.12619 } \\
\hline 4.1415e & & & & & & \\
\hline
\end{tabular}

4. 
Tablo 7 (Cont.'d)

\begin{tabular}{|c|c|c|c|c|c|c|c|c|c|c|c|c|c|c|}
\hline Description & Test I & Vessel I & $\begin{array}{c}\text { Oven } \\
\text { Postition }\end{array}$ & $\begin{array}{c}\text { Test } \\
\text { Period } \\
\text { (weeks) }\end{array}$ & $\begin{array}{l}\text { Date } \\
\text { started }\end{array}$ & $\begin{array}{l}\text { Dato } \\
\text { Stopped }\end{array}$ & Sapplo & $\begin{array}{l}\text { Foight } \\
\text { Class } \\
\text { IH }\end{array}$ & $\begin{array}{l}\text { Feight } \\
\text { aless } \\
\text { our }\end{array}$ & $\underset{\substack{\Delta, 3 s \\
(00)}}{\Delta}$ & $\begin{array}{c}\text { SA } \\
\text { Glass }\end{array}$ & $\begin{array}{c}\text { Top } \\
\text { Canister } \\
\text { IN } \\
\text { (o) }\end{array}$ & $\begin{array}{l}\text { Top } \\
\text { Canister } \\
\text { OUT } \\
\text { (g) }\end{array}$ & Anss \\
\hline Bl ank & H3-11 & Nil-67 & 11 & $\begin{array}{l}16.6 \\
13 \\
10.5 \\
28 \\
32.5 \\
39 \\
45.6 \\
52\end{array}$ & $\begin{array}{l}8 / 20 / 87 \\
8 / 20 / 67 \\
8 / 20 / 87 \\
8 / 20 / 87 \\
8 / 20 / 67 \\
6 / 24 / 87 \\
0 / 21 / 87 \\
8 / 21 / 87\end{array}$ & & none & & & & & & & \\
\hline Continuous & Ha-12 & & 3 & $\begin{array}{l}6.5 \\
13 \\
10.5 \\
28 \\
32.5 \\
30.5 \\
45.5 \\
52\end{array}$ & & $21_{8}$ & 10.50 & & & & & & & \\
\hline
\end{tabular}




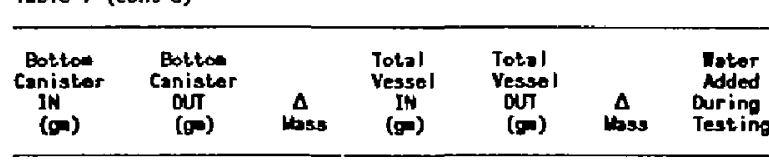


Since the glass received from the MCC had to be remelted to cast the waste form specinens, the composition and redox state may be different from the reported values [MAUPIN]. The physical properties of the glass are being remeasured, and comparative leach tests are being performed to determine whether there is any difference in reactivity between the asreceived and cast glass. A core was taken from bar ATM-10-2 and cut into ten glass disks and a core was taken from sample $2 \mathrm{O}_{2}$ and cored into nine glass disks. MCC -1 type leach tests have been inttiated using DIW and $90^{\circ} \mathrm{C}$. Tests will be run in duplicate with periods of 56 and 91 days. The test matrix is given in Table 8.

\section{B. NNWSI Parametric Experiments (QA level III, act/vity \$0-20-29)}

Because the NNWSI Unsaturated Test rigidly sets many of the test parameters, the effect that each parameter may have on the final radionuclide release needs to be studied. This is being done in parametric experiments. A description, purpose, and status of the parametric experiments in progress are given in Table 9. Each of the ongoing experiments has been discussed in detail previously [STEINDLER, BATES-1, BATES-2] and are continuing as scheduled. Selected parametric experiments are discussed below.

\section{1. $\underline{P-V I}$}

Unsaturated experiments of unirradiated $\mathrm{UO}_{2}$ in different configurations have been ongoing. The 6.5-week sampling periods have been extended to 26 weeks in an attempt to smooth out short-term irregularities in $U$ release and to increase the volume of solution avallable for analysis. The last sampling period was $4 / 23 / 87$ and the updated results are presented in Tables 10, 11, and 12.

The experiments are sampled in the following manner:

1) The $\mathrm{UO}_{2}$ plus zircaloy hoider are removed from the vesse: ar.d placed temporarily in a covered Teflon container;

2) the vessel solution is transferred to a liquid polyethylene (LPE) container;

3) approximately $10 \mathrm{~mL}$ of DIW is added to the vessel (including Teflon stand) and acidified with $\mathrm{HNO}_{3}$ to $1 \%$ by volume; 
Table O. ATL-1E Comparative UCC-1 Leach Tests

\begin{tabular}{|c|c|c|c|c|c|c|c|c|c|c|c|c|}
\hline $\begin{array}{l}\text { Experinent } \\
\text { Type }\end{array}$ & Expt & Suple & $\begin{array}{c}\text { Expt } \\
\text { Duration } \\
\text { (days) }\end{array}$ & Date In & Date dut & $\begin{array}{c}\text { Glass } \\
\text { Thickness }\end{array}$ & $\begin{array}{c}\text { Olass } \\
\text { Dianetor }\end{array}$ & $\begin{array}{c}\text { Gloss } \\
5 A \\
(0-2)\end{array}$ & $\frac{\text { Total }}{\text { Sh }}$ & $\begin{array}{c}\text { Glass } \\
\text { Nass } \\
\text { In (E) }\end{array}$ & $\begin{array}{c}\text { Class } \\
\text { Uass } \\
\text { Dut (g) }\end{array}$ & $\underset{\text { Whes }}{\Delta}$ \\
\hline $\begin{array}{l}\text { ATH-16 Qlass } \\
\text { as recaived } \\
\text { ATH-10-2 }\end{array}$ & $\begin{array}{l}0-567 \\
\text { G-565 } \\
0-569 \\
\text { G-670 } \\
\text { Archivt } \\
\text { Archire }\end{array}$ & 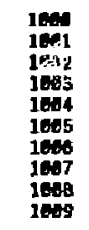 & $\begin{array}{l}66 \\
66 \\
91 \\
91\end{array}$ & $\begin{array}{l}7 / 20 / 67 \\
7 / 29 / 67 \\
7 / 20 / 87 \\
7 / 29 / 67\end{array}$ & & & & $\begin{array}{r}472.05 \\
401.40 \\
477.60 \\
463.20\end{array}$ & & $\begin{array}{r}6.35128 \\
. .35497 \\
.35968 \\
. .36464 \\
. .36289 \\
. .35986 \\
.31144 \\
. .36321 \\
. .36893 \\
. .41899\end{array}$ & & \\
\hline $\begin{array}{l}\text { ATu-10 Olass } \\
\text { once cast } \\
\text { f26-6 }\end{array}$ & $\begin{array}{l}G-571 \\
a-572 \\
G-573 \\
G-574 \\
\text { Archiva }\end{array}$ & $\begin{array}{l}1816 \\
1611 \\
1612 \\
1613 \\
1614 \\
1015 \\
1016 \\
1917 \\
1018\end{array}$ & $\begin{array}{l}60 \\
68 \\
91 \\
91\end{array}$ & $\begin{array}{l}7 / 29 / 87 \\
7 / 29 / 87 \\
7 / 29 / 87 \\
7 / 29 / 87\end{array}$ & & & & $\begin{array}{r}476.94 \\
473.46 \\
477.59 \\
487.82\end{array}$ & & $\begin{array}{r}.35745 \\
.34722 \\
.35147 \\
.34045 \\
.35799 \\
.34364 \\
.36839 \\
.39253 \\
.34836\end{array}$ & & \\
\hline
\end{tabular}


Tubls B (cont'd)

\begin{tabular}{|c|c|c|c|c|c|c|c|c|c|c|}
\hline \multirow{2}{*}{$\begin{array}{c}\text { Leachato } \\
\text { pH } \\
\text { In }\end{array}$} & \multirow{2}{*}{$\begin{array}{c}\text { Leaehate } \\
\text { pH } \\
\text { Out }\end{array}$} & \multirow{2}{*}{$\begin{array}{c}\text { Hass } \\
\text { EJ-13 } \\
\text { In (p) }\end{array}$} & \multirow{2}{*}{$\begin{array}{l}\text { Tot= I } \\
\text { Wass } \\
\text { In }\end{array}$} & \multirow{2}{*}{$\begin{array}{l}\text { Total } \\
\text { Wess } \\
\text { Dut }\end{array}$} & \multirow{2}{*}{ A } & \multirow{2}{*}{$\begin{array}{l}\text { UFE } \\
\text { Hass }\end{array}$} & \multicolumn{4}{|c|}{ Surface Analyes } \\
\hline & & & & & & & Type & Date & Type & Doter \\
\hline 5.56 & & 47.17 & 165.20 & & & & & & & \\
\hline E. ES & & 40.17 & 150.27 & & & & & & & \\
\hline 5.60 & & 47.76 & 15.13 & & & & & & & \\
\hline B. Eg & & 48.37 & 156.73 & & & & & & & \\
\hline 5.56 & & 47.50 & 155.74 & & & & & & & \\
\hline 5.68 & & 47.34 & 165.49 & & & & & & & \\
\hline 5.56 & & 47.78 & $15 n .02$ & & & & & & & \\
\hline 5.58 & & 48.78 & 158.99 & & & & & & & \\
\hline
\end{tabular}


Table 9. Description, Purpose, and Status of Parametric Experiments

\begin{tabular}{|c|c|c|c|}
\hline Experiment & Description & Purpose & Status \\
\hline P-II & $\begin{array}{l}\text { Recular-s1zed glass waste form, } \\
\text { no ss holder, } 0.075 \mathrm{~mL} \mathrm{~J}-13 / \\
3.5 \text { days, continuous and batch } \\
\text { tests }\end{array}$ & $\begin{array}{l}\text { To study the release from } \\
\text { glass only }\end{array}$ & $\begin{array}{l}\text { Inftiated } 2 / 20 / 84 \text { Batch } \\
\text { tests campleted } 2 / 18 / 85 \text {. } \\
\text { Cont inuous tests in progress }\end{array}$ \\
\hline P-III & $\begin{array}{l}\text { Half-sjzed glass waste form, ss } \\
\text { holder, } 0.075 \mathrm{~mL} \text { and Ed-13/ } \\
3.5 \text { days, continuous and batch } \\
\text { tests }\end{array}$ & $\begin{array}{l}\text { To study the effect of } \\
\text { waste form surface area } \\
\text { by reducing the as-cast } \\
\text { surface area by half }\end{array}$ & $\begin{array}{l}\text { Initiated } 12 / 6 / 84 \text { Batch } \\
\text { tests completed } 12 / 5 / 85 \text {. } \\
\text { Cont inuous tests in progress }\end{array}$ \\
\hline P-IV & $\begin{array}{l}\text { Half-sized glass waste form, ss } \\
\text { holder, } 0.0375 \mathrm{~mL} \text { and EJ-13/ } \\
3.5 \text { days, continuous and batch } \\
\text { tests }\end{array}$ & $\begin{array}{l}\text { To study the effect of drop } \\
\text { size by reducing the amount } \\
\text { of water added and the as- } \\
\text { cast surface area by half }\end{array}$ & $\begin{array}{l}\text { Inftiated } 2 / 18 / 85 \text {. Batch } \\
\text { tests completed through one } \\
\text { year. Continuous tests in } \\
\text { progress }\end{array}$ \\
\hline P-V & $\begin{array}{l}\text { Regular-s1zed glass waste form, } \\
\text { ss holder, } 0.075 \mathrm{~mL} \text { and } E, 9-13 / \\
\text { 14 days, continuous and batch } \\
\text { tests }\end{array}$ & $\begin{array}{l}\text { To study the effect of } \\
\text { lengthenting the time } \\
\text { interval between water } \\
\text { additions }\end{array}$ & $\begin{array}{l}\text { Initiated } 6 / 10 / 85 \text {. Batch } \\
\text { tests completed through one } \\
\text { year. Continuous tests in } \\
\text { progress }\end{array}$ \\
\hline P-VI & $\begin{array}{l}\text { Pressed and sintered } \mathrm{UO}_{2} \text { pellets } \\
\text { in various forms, zircaloy } \\
\text { holder, } 0.075 \mathrm{~mL} \text { and } \mathrm{EJ}-13 / \\
3.5 \text { days and } 0.0375 \mathrm{~mL} / 7 \text { days, } \\
\text { continuous tests }\end{array}$ & $\begin{array}{l}\text { To study the release of } v \\
\text { from nonreacted fue } \\
\text { pellets under Unsaturated } \\
\text { Test conditions }\end{array}$ & $\begin{array}{l}\text { Inttiated } 4 / 25 / 85 \text {. Con- } \\
\text { tinuous tests in progress }\end{array}$ \\
\hline \multirow[t]{2}{*}{ P-VII } & $\begin{array}{l}\mathrm{UO}_{2} \text { pel lets soaking in EJ-13 } \\
\text { water at ambient temperature. } \\
\text { batch tests }\end{array}$ & $\begin{array}{l}\text { To look for reaction } \\
\text { product formation }\end{array}$ & $\begin{array}{l}\text { Three- and nine-month batch } \\
\text { test terminated }\end{array}$ \\
\hline & & cont'd & \\
\hline
\end{tabular}


Table 9 (Cont'd)

\begin{tabular}{|c|c|c|c|}
\hline Experiment & Description & Purpose & Status \\
\hline P-VIII & $\begin{array}{l}\text { Regular-sized glass waste forms } \\
\text { in presensitized ss holders, } \\
0.075 \mathrm{~mL} \text { EJ-13/3.5 days, con- } \\
\text { tinuous and batch tests }\end{array}$ & $\begin{array}{l}\text { To study the effect of } \\
\text { presensitizing the ss } \\
\text { waste form holder }\end{array}$ & $\begin{array}{l}\text { Initfated } 2 / 27 / 86 \text {. Batch } \\
\text { tests completed through } \\
\text { six months. Continuous } \\
\text { tests in progress }\end{array}$ \\
\hline P-IX & $\begin{array}{l}\text { A vartety of glasses (polfshed, } \\
\text { as-cut, powdered) in a con- } \\
\text { trolled atmosphere chamber }\end{array}$ & $\begin{array}{l}\text { To stigiy the effect of the } \\
\text { the degree of water satu- } \\
\text { ratio or glass reaction }\end{array}$ & $\begin{array}{l}\text { Intifiated. Selected samples } \\
\text { terminated after ofive } \\
\text { months }\end{array}$ \\
\hline P-X & $\begin{array}{l}\text { Basaltic and SRL-165 glass } \\
\text { vapor hydration tests }\end{array}$ & $\begin{array}{l}\text { To study the use of vapor } \\
\text { phase hydration and } \\
\text { natural and logues in } \\
\text { projecting long-term } \\
\text { glass reaction }\end{array}$ & $\begin{array}{l}\text { Review of existing samples } \\
\text { and itterature initiated }\end{array}$ \\
\hline$P-X 1$ & $\begin{array}{l}\text { SRL } 165 \text { U/A glass, WV U/A } \\
\text { glass, and ATM-1C/8 hyćration }\end{array}$ & $\begin{array}{l}\text { To study the effect of } \\
\text { time and temperature on } \\
\text { the hydration of nuclear } \\
\text { waste glasses under } \\
\text { saturated conditions }\end{array}$ & $\begin{array}{l}\text { Sample preparation in } \\
\text { progress, prel iminary } \\
\text { matrix completed }\end{array}$ \\
\hline
\end{tabular}


Tablo 16. Test Conditions for $\mathrm{UO}_{2}$ Tests

\begin{tabular}{|c|c|c|c|c|c|c|c|c|c|c|c|c|c|c|c|}
\hline Description & $\begin{array}{c}\text { Test } \\
\text { Ho. }\end{array}$ & $\begin{array}{c}V_{e \rightarrow 561} \\
\text { Ho. }\end{array}$ & $\begin{array}{c}\text { Test } \\
\text { Period } \\
\text { (meeks) }\end{array}$ & $\begin{array}{l}\text { Dato } \\
\text { Startod }\end{array}$ & $\begin{array}{l}\text { Date } \\
\text { Stopped }\end{array}$ & $\underset{\substack{W_{2} \\
\text { In }}}{W_{\mathbf{f}}}$ & $\underset{\substack{w_{2} \\
\text { yoight } \\
\text { Out }}}{w_{0}}$ & $\underset{4035}{\Delta}$ & $\begin{array}{c}\text { Total } \\
\text { SA }\end{array}$ & $\begin{array}{l}\text { Rircaloy } \\
\text { Weight } \\
\text { In }\end{array}$ & $\begin{array}{c}\text { Zircaloy } \\
\text { Toight } \\
\text { Out }\end{array}$ & $\underset{t \rightarrow s s}{\Delta}$ & $\begin{array}{c}\text { Tatal } \\
\text { Yessel } \\
\text { In } \\
\text { (g) }\end{array}$ & $\begin{array}{c}\text { Total } \\
\text { Vessel } \\
\text { Out } \\
\text { (Gm) }\end{array}$ & $\underset{\substack{n=s \\
(g)}}{n}$ \\
\hline \multirow[t]{2}{*}{$\begin{array}{l}\text { 20 sliced } \\
\text { discs } 075 \text { al } \\
3.5 \text { days }\end{array}$} & 1 & & $\begin{array}{l}8.5 \\
5.6 \\
6.5 \\
6.5 \\
6.5 \\
8.5 \\
6.5 \\
6.5 \\
28 \\
20\end{array}$ & $\begin{array}{r}4 / 25 / 85 \\
6 / 28 / 85 \\
7 / 25 / 85 \\
9 / 69 / 85 \\
1 / / 24 / 85 \\
12 / 19 / 86 \\
1 / 23 / 86 \\
3 / 19 / 86 \\
4 / 24 / 86 \\
1 / / 23 / 86\end{array}$ & $\begin{array}{r}6 / 20 / 85 \\
7 / 25 / 85 \\
0 / 09 / 85 \\
10 / 24 / 85 \\
12 / 89 / 85 \\
1 / 23 / 86 \\
3 / 10 / 80 \\
4 / 24 / 86 \\
10 / 23 / 80 \\
4 / 23 / 87\end{array}$ & 29.522 & & & 40.69 & 2.3850 & & & $\begin{array}{l}347.13 \\
355.97 \\
355.49 \\
355.36 \\
356.27 \\
356.17 \\
358.18 \\
358.18 \\
356.25 \\
356.39\end{array}$ & $\begin{array}{l}\text { MA } \\
350.16 \\
350.20 \\
358.14 \\
356.94 \\
350.81 \\
350.84 \\
350.92 \\
359.46 \\
359.42\end{array}$ & $\begin{array}{l}.19 \\
. .77 \\
6.78 \\
.67 \\
.64 \\
6.60 \\
6.74 \\
3.21 \\
3.63\end{array}$ \\
\hline & 2 & & $\begin{array}{l}0.5 \\
5.8 \\
6.5 \\
8.5 \\
8.5 \\
6.5 \\
6.5 \\
4.6 \\
20 \\
20\end{array}$ & $\begin{array}{r}4 / 25 / 45 \\
8 / 21 / 85 \\
7 / 25 / 65 \\
9 / 99 / 85 \\
19 / 24 / 85 \\
12 / 90 / 85 \\
1 / 23 / 86 \\
3 / 19 / 86 \\
4 / 24 / 86 \\
16 / 23 / 86\end{array}$ & $\begin{array}{r}6 / 20 / 85 \\
7 / 25 / 85 \\
0 / 69 / 85 \\
10 / 24 / 85 \\
12 / 69 / 85 \\
1 / 23 / 80 \\
3 / 14 / 80 \\
1 / 20 / 80 \\
1 \% / 23 / 80 \\
4 / 23 / 87\end{array}$ & 29.1657 & & & 45.61 & 2.4600 & & & $\begin{array}{l}347.34 \\
355.47 \\
355.60 \\
355.64 \\
358.68 \\
355.73 \\
355.72 \\
355.74 \\
355.74 \\
355.67\end{array}$ & $\begin{array}{l}-- \\
358.11 \\
356.81 \\
358.57 \\
356.89 \\
356.68 \\
356.38 \\
350.64 \\
350.33 \\
359.77\end{array}$ & $\begin{array}{l}-- \\
0.4 \\
1.01 \\
.93 \\
.81 \\
.83 \\
.00 \\
.00 \\
2.03 \\
3.4\end{array}$ \\
\hline \multirow[t]{2}{*}{$\begin{array}{l}\text { Crusted } \mathrm{UD}_{2} \\
\text { a.65 ald } \\
3.5 \text { days }\end{array}$} & 3 & & $\begin{array}{l}8.4 \\
6.1 \\
0.5 \\
8.5 \\
6.5 \\
8.5 \\
0.5 \\
0.5 \\
20 \\
20\end{array}$ & 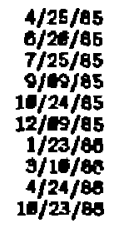 & $\begin{array}{r}6 / 71 / 85 \\
7 / 25 / 85 \\
0 / 69 / 85 \\
16 / 24 / 85 \\
12 / 69 / 85 \\
1 / 23 / 80 \\
3 / 19 / 80 \\
4 / 24 / 80 \\
19 / 23 / 68 \\
4 / 23 / 87\end{array}$ & 19.8502 & & & 340 & 2.3681 & & & $\begin{array}{l}337.54 \\
-- \\
346.55 \\
345.86 \\
346.79 \\
348.74 \\
346.76 \\
346.64 \\
346.84 \\
340.62\end{array}$ & $\begin{array}{c}-- \\
-- \\
347.34 \\
317.44 \\
347.54 \\
347.66 \\
347.61 \\
347.63 \\
354.20 \\
349.93\end{array}$ & $\begin{array}{r}-- \\
-.79 \\
6.79 \\
8.78 \\
6.75 \\
6.82 \\
6.85 \\
6.83 \\
3.42 \\
3.31\end{array}$ \\
\hline & 4 & & $\begin{array}{r}0.0 \\
5 . \\
6.5 \\
6.5 \\
6.5 \\
6.5 \\
6.5 \\
6.5 \\
26\end{array}$ & $\begin{array}{c}4 / 25 / 85 \\
8 / 20 / 85 \\
7 / 25 / 85 \\
9 / 69 / 85 \\
10 / 24 / 85 \\
12 / 69 / 85 \\
1 / 23 / 80 \\
3 / 10 / 89 \\
4 / 24 / 68 \\
\text { Tern inated }\end{array}$ & $\begin{array}{r}6 / 20 / 85 \\
1 / 25 / 65 \\
9 / 69 / 85 \\
10 / 24 / 85 \\
12 / 89 / 85 \\
1 / 29 / 86 \\
3 / 10 / 80 \\
4 / 24 / 86 \\
10 / 23 / 86\end{array}$ & 18.2684 & Cont'd & & 305 & 2.3784 & & & $\begin{array}{l}334.14 \\
342.86 \\
343.34 \\
343.46 \\
343.43 \\
343.30 \\
343.50 \\
343.25 \\
343.68\end{array}$ & $\begin{array}{l}343.5 \\
344.17 \\
344.27 \\
344.18 \\
344.17 \\
344.13 \\
343.50 \\
345.25\end{array}$ & $\begin{array}{l}. .84 \\
.83 \\
.81 \\
.75 \\
.81 \\
.89 \\
.25 \\
1.57\end{array}$ \\
\hline
\end{tabular}


Table 10 (Cont'd)

\begin{tabular}{|c|c|c|c|c|c|c|c|c|c|c|c|c|c|c|c|}
\hline Descr iption & $\begin{array}{l}\text { Test } \\
\text { Mo. }\end{array}$ & $\begin{array}{l}\text { Veasel } \\
\text { no. }\end{array}$ & $\begin{array}{c}\text { Test } \\
\text { Pariod } \\
\text { (veaths) }\end{array}$ & $\begin{array}{l}\text { Dote } \\
\text { Sterted }\end{array}$ & $\begin{array}{c}\text { Dote } \\
\text { Stopped }\end{array}$ & $\begin{array}{l}\mathbf{N o}_{2} \\
\text { voight } \\
\text { In }\end{array}$ & 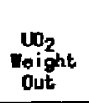 & $\underset{\text { unss }}{\Delta}$ & $\begin{array}{c}\text { Total } \\
\text { SA }\end{array}$ & $\begin{array}{l}\text { Zircaley } \\
\text { Teight } \\
\text { In }\end{array}$ & $\begin{array}{c}\text { Ziresloy } \\
\text { woight } \\
\text { Dut }\end{array}$ & Doss & $\begin{array}{c}\text { Total } \\
\text { Vessel } \\
\text { In } \\
\text { (g) }\end{array}$ & $\begin{array}{c}\text { Total } \\
\text { Vessel } \\
\text { Dut } \\
\text { (go) }\end{array}$ & $\begin{array}{c}\Delta \\
\text { Lass } \\
(\theta)\end{array}$ \\
\hline \multirow[t]{2}{*}{$\begin{array}{l}2 \text { pellets } \\
6.075 \text { iL/ } \\
3.5 \text { days }\end{array}$} & 5 & & $\begin{array}{l}6.4 \\
6.4 \\
8.5 \\
8.5 \\
0.5 \\
0.5 \\
6.5 \\
6.5 \\
28 \\
28\end{array}$ & $\begin{array}{r}1 / 25 / 85 \\
6 / 2 / 85 \\
7 / 25 / 85 \\
9 / / 69 / 85 \\
10 / 24 / 85 \\
12 / 9 / 85 \\
1 / 23 / 86 \\
3 / 10 / 86 \\
1 / 21 / 80 \\
16 / 23 / 86\end{array}$ & $\begin{array}{r}0 / 24 / 85 \\
7 / 25 / 85 \\
9 / 10 / 65 \\
1 / 24 / 85 \\
12 / 9 / 85 \\
1 / 23 / 86 \\
3 / 10 / 86 \\
1 / 24 / 86 \\
1 / / 29 / 85 \\
4 / 23 / 87\end{array}$ & 47.8550 & & & 22.10 & 3.6394 & & & $\begin{array}{c}368.47 \\
-- \\
368.76 \\
368.86 \\
388.97 \\
368.75 \\
358.85 \\
368.97 \\
369.22 \\
369.62\end{array}$ & $\begin{array}{c}-- \\
369.81 \\
359.84 \\
369.74 \\
369.52 \\
369.92 \\
359.89 \\
372.04 \\
372.23\end{array}$ & $\begin{array}{r}-- \\
-- \\
6.85 \\
.74 \\
.77 \\
.77 \\
1.07 \\
.92 \\
3.62 \\
3.41\end{array}$ \\
\hline & b & & $\begin{array}{l}8.4 \\
5.8 \\
8.5 \\
8.5 \\
6.5 \\
8.5 \\
8.5 \\
8.5 \\
20 \\
20\end{array}$ & 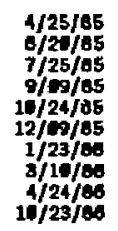 & 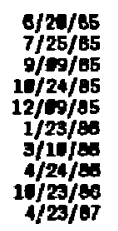 & $40.35 \%$ & & & 22.23 & 5.8639 & & & $\begin{array}{l}367.45 \\
-. \\
375.20 \\
375.20 \\
375.45 \\
375.73 \\
376.84 \\
375.93 \\
376.61 \\
375.61\end{array}$ & $\begin{array}{c}-. . \\
378.18 \\
378.45 \\
376.76 \\
376.49 \\
376.21 \\
376.16 \\
378.90 \\
378.76\end{array}$ & $\begin{array}{l}-- \\
-.76 \\
.77 \\
.76 \\
.76 \\
6.43 \\
.22 \\
2.95 \\
3.14\end{array}$ \\
\hline \multirow[t]{2}{*}{$\begin{array}{l}2 \text { poll lots } \\
1.6375=L / \\
14 \text { days }\end{array}$} & 7 & & $\begin{array}{l}13 \\
13 \\
13 \\
13 \\
20 \\
20\end{array}$ & $\begin{array}{r}4 / 25 / 85 \\
7 / 25 / 185 \\
10 / 24 / 45 \\
i / 23 / 86 \\
1 / 24 / 86 \\
11 / 23 / 86\end{array}$ & $\begin{array}{r}7 / 25 / 85 \\
19 / 24 / 85 \\
1 / 23 / 80 \\
4 / 24 / 80 \\
10 / 23 / 80 \\
4 / 23 / 87\end{array}$ & 47.6965 & & & 21.92 & 3.0405 & & & $\begin{array}{l}368.60 \\
374.69 \\
375.17 \\
375.11 \\
375.19 \\
375.6\end{array}$ & $\begin{array}{c}375.68 \\
10 \\
375.40 \\
375.91 \\
375.59\end{array}$ & $\begin{array}{l}. .67 \\
60 \\
6.39 \\
6.72 \\
6.52\end{array}$ \\
\hline & - & & $\begin{array}{l}13 \\
13 \\
13 \\
13 \\
20 \\
20\end{array}$ & $\begin{array}{r}4 / 25 / 85 \\
7 / 25 / 65 \\
1 / / 24 / 85 \\
1 / 23 / 86 \\
4 / 24 / 86 \\
10 / 23 / 86\end{array}$ & $\begin{array}{r}7 / 25 / 85 \\
1 / 25 / 85 \\
1 / 23 / 85 \\
4 / 24 / 85 \\
11 / 23 / 88 \\
4 / 23 / 87\end{array}$ & 47.7734 & & & 22.10 & 3.4958 & & & $\begin{array}{l}366.78 \\
375.06 \\
375.68 \\
375.16 \\
375.35 \\
375.32\end{array}$ & $\begin{array}{c}-\overline{37.55} \\
37 . .5 \\
376.79 \\
376.13 \\
375.69\end{array}$ & $\begin{array}{l}-. \\
.51 \\
.39 \\
.69 \\
.79 \\
.37\end{array}$ \\
\hline
\end{tabular}

The netal closure fitting was wot during wighing. 
Table 11. Solution Analysis from $\mathrm{NO}_{2}$ Parametric Tests Series P-VI

\begin{tabular}{|c|c|c|c|}
\hline Test \# & Analysis & $\begin{array}{l}\text { Solutiona } \\
\text { Vol } \\
(\mathrm{mL})\end{array}$ & $\begin{array}{c}\text { Total } \\
\text { Nanogram } \\
\text { U }\end{array}$ \\
\hline PMP 8U-1 & $\begin{array}{l}\text { TF }-174 \\
\text { TF-189 } \\
\text { TF-214 } \\
\text { TF-229 } \\
\text { TF-245 } \\
\text { TF-260 } \\
\text { TF-276 } \\
\text { TF-294 } \\
\text { TF-356 } \\
\text { TF-432 }\end{array}$ & $\begin{array}{l}- \\
0.19 \\
0.77 \\
0.78 \\
0.67 \\
0.64 \\
0.66 \\
0.74 \\
3.21 \\
3.03 \\
\text { TOTAL }\end{array}$ & $\begin{array}{r}26,200 \\
21,600 \\
449,300 \\
263,700 \\
129,300 \\
74,500 \\
1,001,000 \\
2,160,000 \\
273,700 \\
168,100 \\
4,576,000\end{array}$ \\
\hline PHP BU-2 & $\begin{array}{l}T F-175 \\
T F-190 \\
T F-215 \\
T F-230 \\
T F-246 \\
T F-261 \\
T F-277 \\
T F-295 \\
\text { TF-357 } \\
\text { TF-433 }\end{array}$ & $\begin{array}{l}- \\
0.64 \\
1.01 \\
0.93 \\
0.81 \\
0.83 \\
0.66 \\
0.80 \\
2.63 \\
3.40 \text { TOTAL }\end{array}$ & $\begin{array}{r}11,000 \\
25,700 \\
388,100 \\
201,300 \\
56,100 \\
38,300 \\
46,900 \\
1,945,000 \\
1,490,000 \\
104,800 \\
4,308,000\end{array}$ \\
\hline PMP 8U-3 & $\begin{array}{l}\text { TF-176 } \\
\text { TF-191 } \\
\text { TF-216 } \\
\text { TF-231 } \\
\text { TF-247 } \\
\text { TF-262 } \\
\text { TF-278 } \\
\text { TF-296 } \\
\text { TF-358 } \\
\text { TF-434 }\end{array}$ & $\begin{array}{l}- \\
- \\
0.79 \\
0.78 \\
0.75 \\
0.82 \\
0.85 \\
0.83 \\
3.42 \\
3.31 \text { TOTAL }\end{array}$ & $\begin{array}{r}280 \\
5,900 \\
71,300 \\
126,300 \\
88,000 \\
31,100 \\
194,600 \\
130,700 \\
265,800 \\
138,700 \\
1,053,000\end{array}$ \\
\hline
\end{tabular}

Cont'd 
Table 11 (Cont'd)

\begin{tabular}{|c|c|c|c|}
\hline Test \# & Analysis & $\begin{array}{l}\text { Solutiona } \\
\text { Vol } \\
\text { (mL) }\end{array}$ & $\begin{array}{l}\text { Total } \\
\text { Nanogram } \\
\text { U }\end{array}$ \\
\hline PMP 8U-4 & $\begin{array}{l}\text { TF-177 } \\
\text { TF-192 } \\
\text { TF-217 } \\
\text { TF-232 } \\
\text { TF }-248 \\
\text { TF-263 } \\
\text { TF-279 } \\
\text { TF-297 } \\
\text { TF-359 } \\
\text { Terminated }\end{array}$ & $\begin{array}{l}- \\
0.64 \\
0.83 \\
0.81 \\
0.75 \\
0.81 \\
0.63 \\
0.25 \\
1.57 \\
\\
\end{array}$ & $\begin{array}{r}2,680 \\
7,700 \\
9,200 \\
9,670 \\
193,100 \\
113,200 \\
623,800 \\
967,000 \\
1,400,000 \\
3,326,000\end{array}$ \\
\hline PHP BU-5 & $\begin{array}{l}\text { TF-178 } \\
\text { TF-193 } \\
\text { TF-218 } \\
\text { TF-233 } \\
\text { TF-249 } \\
\text { TF-264 } \\
\text { TF-280 } \\
\text { TF-298 } \\
\text { TF-360 } \\
\text { TF- } 435\end{array}$ & $\begin{array}{l}- \\
- \\
0.85 \\
0.76 \\
0.77 \\
0.77 \\
1.07 \\
0.92 \\
3.62 \\
3.45 \text { TOTAL }\end{array}$ & $\begin{array}{r}2,847 \\
1,220 \\
109,400 \\
36,100 \\
33,800 \\
19,400 \\
321,700 \\
71,000 \\
103,100 \\
478,000 \\
1,176,600\end{array}$ \\
\hline PHP 8U-6 & $\begin{array}{l}\text { TF-179 } \\
\text { TF-194 } \\
\text { TF-219 } \\
\text { TF-234 } \\
\text { TF-250 } \\
\text { TF-265 } \\
\text { TF-281 } \\
\text { TF-299 } \\
\text { TF-361 } \\
\text { TF-436 }\end{array}$ & $\begin{array}{l}- \\
- \\
0.78 \\
0.77 \\
0.70 \\
0.76 \\
0.43 \\
0.22 \\
2.95 \\
3.14 \text { TOTAL }\end{array}$ & $\begin{array}{r}2,610 \\
2,947 \\
30,400 \\
41,900 \\
798,000 \\
1,390,800 \\
55,800 \\
593,000 \\
3,760,000 \\
389,000 \\
7,065,000\end{array}$ \\
\hline PMP 8U-7 & $\begin{array}{l}\text { TF- } 195 \\
\text { TF-235 } \\
\text { TF-266 } \\
\text { TF-300 } \\
\text { TF-362 } \\
\text { TF-437 }\end{array}$ & $\begin{array}{l}- \\
0.67 \\
- \\
0.39 \\
0.72 \\
0.52 \\
\quad \text { TOTAL }\end{array}$ & $\begin{array}{r}1,059 \\
301,900 \\
95,300 \\
665,000 \\
1,070,000 \\
225,000 \\
2,358,000\end{array}$ \\
\hline
\end{tabular}


Table 11 (Cont'd)

\begin{tabular}{|c|c|c|c|}
\hline Test * & $\begin{array}{c}\text { Analysis } \\
\#\end{array}$ & $\begin{array}{l}\text { Solutiona } \\
\text { Vol } \\
(\mathrm{mL})\end{array}$ & $\begin{array}{c}\text { Total } \\
\text { Nanogram } \\
U\end{array}$ \\
\hline PMP 8U-8 & $\begin{array}{l}\text { TF-196 } \\
\text { TF-236 } \\
\text { TF-267 } \\
\text { TF-301 } \\
\text { TF-363 } \\
\text { TF-438 }\end{array}$ & $\begin{array}{l}- \\
0.51 \\
0.39 \\
0.63 \\
0.78 \\
0.37 \text { TOTAL }\end{array}$ & $\begin{array}{r}875 \\
525,000 \\
246,600 \\
264,000 \\
5,950,000 \\
2,107,000 \\
9,093,000\end{array}$ \\
\hline
\end{tabular}

aThis is the total amount of EJ-13 water added dropwise during an exporimental period. It does not include $0.5 \mathrm{~mL}$ of EJ-13 that is added every sampling period before the vessels are sealed.

NOTE - The total nanograms of uranium release is based on an acid strip of the vessel and TeflonTh stand. The concentration of uranium in solution cannot be calculated in the experiment as conducted. 
Table 12. Analysis of Solutiona Composition from P-VI Experiments (4/23/87 Sampling Period)

\begin{tabular}{|c|c|c|c|c|c|c|c|c|c|c|}
\hline \multirow{2}{*}{ Experiment } & \multicolumn{3}{|c|}{ Composition (total } & \multicolumn{2}{|c|}{ nanograms) of } & \multicolumn{2}{|c|}{ Leachate at the } & $4 / 23 / 87$ & \multicolumn{2}{|c|}{ Sampling Period } \\
\hline & Al & $\mathbf{B}$ & $\mathbf{C a}$ & $\mathbf{F e}$ & Li & $\mathrm{Mg}$ & Mת & $\mathrm{Na}$ & si & K \\
\hline 1 & 1500 & 900 & 3300 & 230 & 200 & 840 & 430 & 177400 & 53500 & 10400 \\
\hline 2 & $<1400$ & 860 & 4800 & 330 & 230 & $\cdot 000$ & 200 & 161700 & 66000 & 10600 \\
\hline 3 & $<1300$ & 1400 & 4000 & 500 & 800 & 3900 & 600 & 180000 & 33000 & 8400 \\
\hline 5 & $<1300$ & 970 & 2400 & 500 & 200 & $\mathbf{8 0 0}$ & 1200 & 191300 & 52900 & 9700 \\
\hline 6 & 2800 & 1000 & 5400 & 360 & 190 & 800 & 240 & 173600 & 55600 & 10500 \\
\hline 7 & 1700 & 500 & 6500 & 570 & $<150$ & 400 & 61700 & 56100 & 11100 & $<7900$ \\
\hline 8 & 13400 & 2200 & 3900 & 800 & $<150$ & 440 & 700 & 40100 & 11700 & $<7900$ \\
\hline
\end{tabular}

aRaw solution compositions, not corrected for addition of EJ-13 water during the experiment. Only the solution collected during the 4/23/87 sampling period has been analyzed for cations other than uranfum. 
4) the vessel is soaked for five minutes and the liquid is transferred to the LPE;

5) the vessel is rinsed with DIW and $0.5 \mathrm{~mL}$ of EJ-13 is added;

6) the $\mathrm{UO}_{2}$ plus Zircaloy is returned to the vesse i $_{\text {; }}$

7) the vessel is weighed, sealed, and put back on line.

The uranium detected in the sample solutions represents all of the uranium that has been released from the $\mathrm{UO}_{2}$ plus Zircaloy except for that which is retained on the Teflon holder after acidification; however, no attempt has been made to determine whether the $U$ is in solution, exists as particulates, or is sorbed to the vessel walls. A yellow precipitate has formed on the top and bottom surfaces of the $\mathrm{UO}_{2}$ pellets and on the Teflon stand. After acidification some of the yellow precipitate remalns on the Teflon stand and thus it is 1ikely that incomplete measurement of all $\mathrm{U}$ released from the waste form has been made.

The data (Tables 10 and 11) indicate that in most experiments a fairly constant amount, $\sim 0.75 \mathrm{~mL}$, of water accumulates every 6.5 weeks. In some experiments this volume has decreased as the experiments have continued. This is a real effect and results when the inlet lines become plugged. If such plugging is observed, the vessels are supposed to be placed in a new position in the oven. Vessel relocation has been effected in all cases where plugging has been verified, but in some cases several sampling periods have been required to complete the move.

The data also indicate that there is no obvious trend to the release patterns, either between duplicate experiments, or between the different sets of experiments. However, it does seem clear that in experiments 7 and 8 , where the water contact has been reduced by a factor of eight and the surface area decreased by a factor of fifteen, the total amount of uranium actually released is not noticeably affected when compared to the other experimental designs used.

Whether these release trends are a function of experimental uncertainties or of different reaction processes, is not known. However, incomplete dissolution of the yellow precipitate from the ieflon stand likely is one cause for the scatter in the data. The yellow precipitate has been identified by XRD as $\mathrm{U}_{3} \mathrm{O}_{8} \cdot \mathrm{O}_{3} 8 \mathrm{H}_{2} \mathrm{O}$, and unique spectra have been collected using Raman microprobe. 


\section{P-VIII}

This set of experiments was initiated simultaneously with the N2 Tests and utilized $304 \mathrm{~L}$ stainless steel waste form holders that had been heated at $\sim 550^{\circ} \mathrm{C}$ for 24 hours, obstensibly the same procedure used to sensitize the holders in the $\mathrm{N} 2$ Tests. However, the heat treatment was not done at the same time as the 12 Tests and the $304 \mathrm{~L}$ steel used in the P-VIII experiments was from a different heat than used in the N2 Tests. The purpose of the P-VIII experiments was to duplicate the N2 Tests using SRL 165 type glass doped only with $U$ (no transuranics). The effective glass composition between the N2 Tests and the P-VIII experiments was the same; however, extensive surface analyses were possible on the P-VIII components, while similar analyses on the N2 components would be difficult due to transuranic contamination.

The results of the P-VIII experiments through 65 weeks are presented in Tables 13, 14, and 15. The appearance of the glass and metal components was strikingly different from that observed in the N2 Tests in that, except for test P-VIII \$6, there were no rust-colored precipitates and no evidence for strong interaction between the test components. This observation was reinforced by the solution results which indicate a release commensurate with experiments of minimal ss/glass interaction. The exception was experiment $P$-VIII $\$ 6$ where the elemental releases were indicative of a stronger interaction.

The metal test components showed no evidence of sensitization for the experiments P-VIII \& 3 -5. Experiment P-VIII $\$ 6$ has yet to be examined. These results are consistent with those found in the F-1 [BATES-3], N-2, and analog test series in that the exterit of glass reaction correlates well with the degree to which the metal is sensitized.

\section{3. $P-I X$}

\section{a. Vapor Hydration Experiments}

Parametric experiments are in progress (1) to elucidate the fundamental processes that occur during protracted reaction of silicate and borosilicate glass surfaces (Table 16) with water, and (2) to investigate directly investigate the rate and products of vapor-phase hydration of nuclear waste glasses. These experiments are a continuation of vapor 
Tablo 13. Experimentsl betrix and Results froe Paranolrie Experinents (P-YIII Sories)

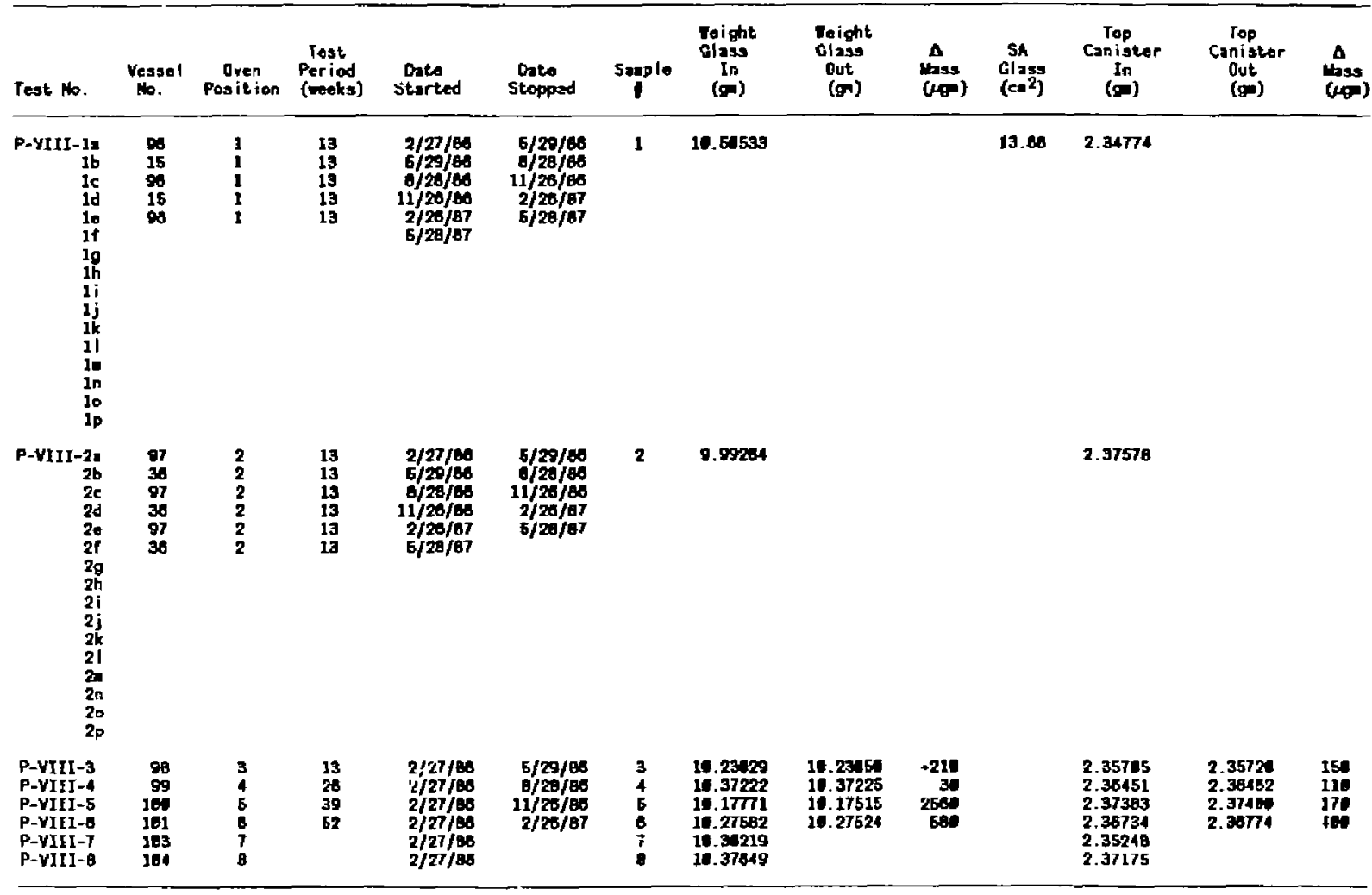


Table 13 (Cont'd)

\begin{tabular}{|c|c|c|c|c|c|c|}
\hline $\begin{array}{l}\text { Bottom } \\
\text { Canister } \\
\text { In } \\
\text { (g) }\end{array}$ & $\begin{array}{l}\text { Bottoe } \\
\text { Canister } \\
\text { Dut } \\
\text { (g) }\end{array}$ & $\underset{\text { (uss }}{\Delta}$ & $\begin{array}{c}\text { Total } \\
\text { Vessel } \\
\text { In } \\
(0)\end{array}$ & $\begin{array}{l}\text { Total } \\
\text { Vossel } \\
\text { Dut } \\
\text { (g) }\end{array}$ & $\underset{\Delta \text { ss }}{\Delta}$ & $\begin{array}{l}\text { Water } \\
\text { Added } \\
\text { During } \\
\text { Testing }\end{array}$ \\
\hline 3.35991 & & & $\begin{array}{l}322.10 \\
327.34 \\
326.30 \\
327.80 \\
328.60 \\
327.6\end{array}$ & $\begin{array}{l}321.76 \\
320.00 \\
934.16 \\
329.21 \\
330.31\end{array}$ & $\begin{array}{l}1.58 \\
1.46 \\
1.7 \\
1.64 \\
1.63\end{array}$ & $\begin{array}{l}1.95 \\
1.95 \\
1.95 \\
1.95 \\
2.95\end{array}$ \\
\hline
\end{tabular}

9. 34846

$\begin{array}{llll}397.34 & 328.00 & 1.65 & 1.95 \\ 334.06 & 336.47 & 1.69 & 1.95 \\ 335.43 & 337.01 & 1.67 & 1.95 \\ 335.22 & 338.60 & 1.66 & 1.06 \\ 335.84 & 337.4 & 1.64 & 1.95 \\ 335.14 & & & \end{array}$

\begin{tabular}{|c|c|c|c|c|c|c|}
\hline $\begin{array}{l}3.30162 \\
3.39765 \\
3.95271 \\
3.39773 \\
3.35928 \\
3.35672\end{array}$ & $\begin{array}{l}3.36102 \\
\text { 3.33776 } \\
\text { 3.35291 } \\
\text { 3.39623 }\end{array}$ & ${ }_{200}^{120}$ & $\begin{array}{l}325.50 \\
324.55 \\
324.34 \\
325.82 \\
325.71 \\
325.71\end{array}$ & $\begin{array}{l}321.18 \\
323.74 \\
328.7 \\
331.74\end{array}$ & $\begin{array}{l}1.69 \\
3.14 \\
4.82 \\
5.92\end{array}$ & $\begin{array}{l}1.05 \\
2.09 \\
5.05 \\
7.8\end{array}$ \\
\hline
\end{tabular}


Table 14. Solution Resulte (Total Hanograns) for P-vIII Experimontel Seriea

\begin{tabular}{|c|c|c|c|c|c|c|c|c|c|c|c|c|c|c|}
\hline Exporimont & $A n \in \mid y=1=$ & $\begin{array}{l}\text { Solution } \\
\text { Yof } \\
\text { (mL) }\end{array}$ & Af & $\mathbf{\theta}$ & ca & $F_{\bullet}$ & C: & wo & Wn & Ne & Ni & si & $\mathbf{s r}$ & $\mathbf{u}$ \\
\hline $\begin{array}{r}\text { P-virt-1a } \\
1 b \\
1 \mathrm{c} \\
1 \mathrm{~d} \\
10\end{array}$ & $\begin{array}{l}\text { TF } 318 \\
\text { TF } 342 \\
\text { TF } 388 \\
\text { TF } 421 \\
\text { TF } 451\end{array}$ & $\begin{array}{l}21.93 \\
19.92 \\
12.16 \\
14.17 \\
13.72\end{array}$ & $\begin{array}{l}\$ 2260 \\
\langle 1960 \\
\langle 1260 \\
\langle 1460 \\
\langle 1460\end{array}$ & $\begin{array}{r}2900 \\
1560 \\
<300 \\
720 \\
720\end{array}$ & $\begin{array}{l}4206 \\
3760 \\
2206 \\
3100 \\
440\end{array}$ & $\begin{array}{l}40964 \\
43760 \\
00000 \\
8160 \\
9600\end{array}$ & $\begin{array}{l}9000 \\
6900 \\
4000 \\
3300 \\
4700\end{array}$ & $\begin{array}{l}420 \\
270 \\
280 \\
270 \\
410\end{array}$ & $\begin{array}{r}6360 \\
3060 \\
2800 \\
670 \\
480\end{array}$ & $\begin{array}{r}76800 \\
107260 \\
86760 \\
82160 \\
141360\end{array}$ & $\begin{array}{c}8300 \\
8900 \\
\text { NA } \\
\text { NA } \\
\text { topen }\end{array}$ & $\begin{array}{r}14560 \\
183960 \\
12860 \\
53100 \\
77160\end{array}$ & $\begin{array}{r}<10 \\
6100 \\
681 \\
<70 \\
<70\end{array}$ & $\begin{array}{r}485 \\
253 \\
98 \\
58 \\
58\end{array}$ \\
\hline $\begin{array}{r}\text { P-VIII-2e } \\
2 b \\
2 c \\
2 d \\
2 a\end{array}$ & $\begin{array}{l}\text { TF } 319 \\
\text { TF } 343 \\
\text { TF } 389 \\
\text { TF } 422 \\
\text { TF } 452\end{array}$ & $\begin{array}{l}26.04 \\
19.23 \\
13.46 \\
13.68 \\
14.37\end{array}$ & 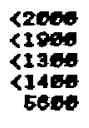 & $\begin{array}{r}2700 \\
2060 \\
5400 \\
775 \\
720\end{array}$ & $\begin{array}{l}3100 \\
6006 \\
1600 \\
3106 \\
4560\end{array}$ & $\begin{array}{l}13600 \\
79400 \\
22400 \\
0500 \\
8600\end{array}$ & $\begin{array}{l}7700 \\
6700 \\
5270 \\
8300 \\
5206\end{array}$ & $\begin{array}{r}350 \\
1700 \\
150 \\
278 \\
436\end{array}$ & $\begin{array}{r}1600 \\
8660 \\
1160 \\
986 \\
376\end{array}$ & $\begin{array}{r}73206 \\
94400 \\
16500 \\
108006 \\
188200\end{array}$ & $\begin{array}{c}3506 \\
15460 \\
\text { NA } \\
\text { NA } \\
\text { 900 }\end{array}$ & $\begin{array}{l}52900 \\
87360 \\
7606 \\
69806 \\
96660\end{array}$ & $\begin{array}{l}<110 \\
<106 \\
<70 \\
268 \\
270\end{array}$ & $\begin{array}{r}391 \\
272 \\
<11 \\
52 \\
67\end{array}$ \\
\hline $\begin{array}{r}\text { P-VIII-a } \\
4 \\
5 \\
0\end{array}$ & $\begin{array}{ll}\text { TF } & 320 \\
\text { TF } & 344 \\
\text { TF } & 301 \\
\text { TF } & 423\end{array}$ & $\begin{array}{l}21.42 \\
18.83 \\
14.05 \\
13.63\end{array}$ & $\begin{array}{l}2100 \\
2600 \\
3000 \\
6700\end{array}$ & $\begin{array}{r}2760 \\
6700 \\
4260 \\
34860\end{array}$ & $\begin{array}{c}1300 \\
7760 \\
16500 \\
12800\end{array}$ & $\begin{array}{r}9060 \\
117760 \\
\text { 8abeg } \\
\text { 39706 }\end{array}$ & $\begin{array}{l}11006 \\
26260 \\
23960 \\
64866\end{array}$ & $\begin{array}{l}460 \\
960 \\
778 \\
946\end{array}$ & $\begin{array}{l}1300 \\
4706 \\
6460 \\
6760\end{array}$ & $\begin{array}{l}2180000 \\
290000 \\
323200 \\
520700\end{array}$ & $\begin{array}{c}2869 \\
13260 \\
\mathrm{NA} \\
\mathrm{NA}\end{array}$ & $\begin{array}{r}72600 \\
220100 \\
156060 \\
306060\end{array}$ & $\begin{array}{r}6110 \\
94 \\
165 \\
330\end{array}$ & $\begin{array}{r}1161 \\
1165 \\
974 \\
13766\end{array}$ \\
\hline
\end{tabular}


Table 16. Blank Corroctod Tatala" for Puranetric P-YIII Test Series Solutions

\begin{tabular}{|c|c|c|c|c|c|c|c|c|c|c|c|c|c|c|c|}
\hline & & & $\begin{array}{l}\text { EJ-13 }(\mathrm{g} / \mathrm{AL}) \\
\text { (orter }[/ 6 / \Delta 7)\end{array}$ & $\begin{array}{l}716 \\
210\end{array}$ & $\begin{array}{l}185 \\
160\end{array}$ & 150 & $\$ 10$ & E4 & 406 & $\begin{array}{l}<5 \\
<6\end{array}$ & 481EA & & $\begin{array}{l}37251 \\
34604\end{array}$ & 45 & 21.9 \\
\hline Test & $\begin{array}{l}\text { Tine } \\
\text { Poriod } \\
\text { (reeks) }\end{array}$ & Tater $(\mathrm{L})$ & $\begin{array}{l}\text { EJ-13 in } \\
\text { Vossoli } \\
\text { (CL) }\end{array}$ & A! & B & ca & $F_{0}$ & $\mathbf{L i}$ & 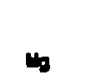 & $m$ & No & Mi & si & Sr & $\mathbf{u}$ \\
\hline $\begin{array}{r}\text { P-VIII-1s } \\
\text { 1b } \\
1 c \\
1 d \\
10\end{array}$ & $\begin{array}{l}13 \\
13 \\
13 \\
13 \\
13\end{array}$ & $\begin{array}{l}1.95=0.2 \\
1.05=0.2 \\
1.05: 0.2 \\
1.05=0.2 \\
1.05=6.2\end{array}$ & $\begin{array}{l}2.15 \\
2.16 \\
2.15 \\
2.16 \\
2.16\end{array}$ & & $\begin{array}{l}2400 \\
1160 \\
34 \\
34\end{array}$ & 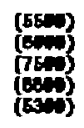 & & 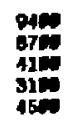 & $\begin{array}{l}(44) \\
(6-5) \\
(6-5) \\
(5-5)\end{array}$ & & $\begin{array}{c}(20000) \\
3000 \\
(22705) \\
(11300) \\
30300\end{array}$ & & $\begin{array}{c}(35000) \\
23040) \\
(37300) \\
(27000) \\
(300)\end{array}$ & & $\begin{array}{r}455 \\
243 \\
88 \\
48 \\
47\end{array}$ \\
\hline $\begin{array}{r}\text { P-VIII-2a } \\
2 b \\
2 c \\
2 d \\
2 a\end{array}$ & $\begin{array}{l}13 \\
13 \\
13 \\
13 \\
13\end{array}$ & $\begin{array}{l}1.95=8.2 \\
1.05=8.2 \\
1.05 \div 8.2 \\
1.05=0.2 \\
1.95=6.2\end{array}$ & $\begin{array}{l}2.15 \\
2.16 \\
2.16 \\
2.16 \\
2.16\end{array}$ & & $\begin{array}{c}2700 \\
100 \\
30 \\
304\end{array}$ & 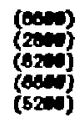 & & $\begin{array}{l}\text { TEN } \\
\text { SED } \\
\text { sin }\end{array}$ & $\begin{array}{l}(510) \\
(1+4) \\
(14)\end{array}$ & & 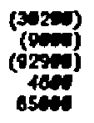 & & $\begin{array}{c}(272 a) \\
7294 \\
(73104) \\
\text { (at3e) } \\
1654\end{array}$ & & $\begin{array}{c}391 \\
162 \\
- \\
42 \\
60\end{array}$ \\
\hline $\begin{array}{l}\text { P-VIII-3 } \\
\text { P-VIIII-4 } \\
\text { P-VIII-5 } \\
\text { P-VIII-5 }\end{array}$ & $\begin{array}{l}13 \\
23 \\
39 \\
52\end{array}$ & $\begin{array}{r}1.86+0.2 \\
3.00+9.2 \\
5.86 \div 2 \\
7.8+1.2\end{array}$ & $\begin{array}{l}2.16 \\
4.10 \\
6.45 \\
6.4\end{array}$ & & $\begin{array}{l}3945 \\
5944 \\
3144 \\
3334\end{array}$ & $\begin{array}{l}\text { (5460) } \\
(1164) \\
(1146)\end{array}$ & & $\begin{array}{l}\text { 1164. } \\
2494 \\
2374 \\
\text { 5454 }\end{array}$ & $\begin{array}{l}(410) \\
(170) \\
(2400)\end{array}$ & & $\begin{array}{r}15504 \\
92806 \\
322204 \\
135924\end{array}$ & & 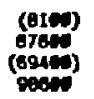 & (96) & $\begin{array}{l}1090 \\
1095 \\
954 \\
13720\end{array}$ \\
\hline
\end{tabular}

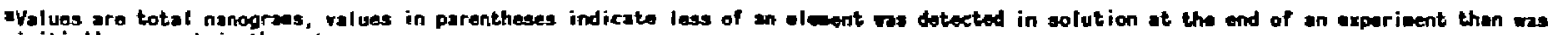

initially present in the water. 
Table 16. Resultsa from the F-1 Unsaturated Test Series

\begin{tabular}{|c|c|c|c|c|c|}
\hline Test No. & Test Description & $\begin{array}{l}\text { Weight Change } \\
\text { (NL) wt, } \mathrm{g} / \mathrm{m}^{2}\end{array}$ & $\begin{array}{l}\text { Total } \\
\text { L. }\end{array}$ & Release, & $\mu \underset{\mathrm{B}}{g}$ \\
\hline $\begin{array}{l}\text { F-1 } \\
\text { F-2 } \\
\text { Sum of Two }\end{array}$ & $\begin{array}{l}\text { 13-week batch } \\
\text { 13-week batch } \\
\text { 6.5-week continuousb }\end{array}$ & $\begin{array}{l}0.26 \\
0.25\end{array}$ & $\begin{array}{r}5.9 \\
6.2 \\
10.0\end{array}$ & & $\begin{array}{l}3.9 \\
5.9 \\
3.3\end{array}$ \\
\hline $\begin{array}{l}\text { F-3 } \\
\text { F-4 } \\
\text { Sum of Four }\end{array}$ & $\begin{array}{l}\text { 26-week batch } \\
26 \text {-week batch } \\
6.5 \text {-week continuous } b\end{array}$ & $\begin{array}{l}0.47 \\
0.40\end{array}$ & $\begin{array}{l}10.9 \\
11.1 \\
20.8\end{array}$ & & $\begin{array}{r}15.1 \\
15.5 \\
5.0\end{array}$ \\
\hline $\begin{array}{l}F-5 \\
F-6 \\
\text { Sum of } 5+x\end{array}$ & $\begin{array}{l}\text { 39-week batch } \\
\text { 39-week batch } \\
6.5 \text {-week cont Inuous }\end{array}$ & $\begin{array}{l}0.71 \\
0.25\end{array}$ & $\begin{array}{l}14.4 \\
10.8 \\
27.5\end{array}$ & & $\begin{array}{r}22.2 \\
5.4 \\
6.3\end{array}$ \\
\hline $\begin{array}{l}F-7 \\
F-8 \\
\text { Sum of Efght }\end{array}$ & $\begin{array}{l}\text { 52-week batch } \\
52 \text {-week batch } \\
6.5 \text {-week cont Inuous }{ }^{b}\end{array}$ & $\begin{array}{l}0.28 \\
0.06\end{array}$ & $\begin{array}{r}10.5 \\
4.4 \\
37.9\end{array}$ & & $\begin{array}{l}4.7 \\
7.1 \\
7.1\end{array}$ \\
\hline $\begin{array}{l}F-9 \\
F-10 \\
F-11\end{array}$ & $\begin{array}{l}52 \text {-week cont inuous } \\
52 \text {-week cont inuous } \\
52 \text {-week cont inuous }\end{array}$ & $\begin{array}{l}0.05 \\
0.06 \\
0.11\end{array}$ & & & \\
\hline
\end{tabular}

aThe release in the batch tests does not account for the amount of Li or $B$ retained by tuff cup and therefore these total releases under represent the total release. No tuff cup was used in the continuous tests so these results are directly comparable to either the results of the $N 2$ tests or of the P-VIII experiments.

baverage of tests $F-10$ and F-11. 
hydration experiments involving nuclear waste glasses (SRL 165, SRL 131, PNL 76-68) at temperatures ranging from $80^{\circ} \mathrm{C}$ to $202^{\circ} \mathrm{C}$ and relative humidities of 50 to $100 \%$ RH. A paper describing the mechanisms of vapor hydration is in preparation.

Present experiments on the above-mentioned nuclear waste glasses at $75^{\circ} \mathrm{C}$ will be used in confirming/refuting the validity of an Arrhenlus-type dependence of reaction rate on temperature. Only a limited number of experiments on monoliths (as opposed to glass powders) were performed at $80^{\circ} \mathrm{C}$ previously, whereas all the ongoing $75^{\circ} \mathrm{C}$ experiments (Table 17) use glass monoliths. Nuclear resonance profiles already collected for SRL glasses hydrated for over 150 days (95\% RH) (Table 17) appear to show that an Arrhenfus relation can predict reaction rates to better than a factor of two even in unsaturated vapor environments [cf. BATES-4].

Hydration experiments on simple silicates, nuclear waste glasses (above), obsidjan and basaltic glass at $75^{\circ} \mathrm{C}$, and relative humidity of 60,95 , and $100 \%$ are in progress for over 270 days. The specific alms of these experiments are (1) to exanine the dependence of hydration rate on relative humidity, (2) to determine if the relationship of hydration rate and humidity vary with glass composition, and (3) to compare the rates and products of hydration of the different glass compositions. Preliminary results of $\mathrm{H}$-profiling indicate that the hydration rate of basalt is greater than that of obsidlan and that of SRL 131 is greater than that of SRL 165. The hydration rate of obsidian appears to be comparable to that of the SRL glasses. SIMS analyses of these samples are underway.

A new experimental submatrix has been designed to study systematically the effect of glass composition on hydration rates at saturated vapor pressures. A compositional series in the system $\mathrm{Na}_{2} \mathrm{O}-\mathrm{CaO}-$ $\mathrm{B}_{2} \mathrm{O}_{3}-\mathrm{Al}_{2} \mathrm{O}_{3}-\mathrm{SlO}_{2}$ has been selected that encompasses the optical basicity and structure of nuclear waste glasses. These experiments will be performed at $75^{\circ} \mathrm{C}$ using deuterated $(99.9 \%)$ and normal water. Oxide mixtures of ail these glasses have been prepared. Cructbles for glass synthesis have been machined from recently acquired high-grade graphite bricks (Union Carbide Stock \#TS 1792). Exploratory experiments using simple glasses (soda silicates) and nuclear waste and natural glasses using $\mathrm{O}_{2} \mathrm{O}$ are in progress. 
Table 17. 1986 Vapor Hydration Experiments for NNWSI

\begin{tabular}{|c|c|c|c|c|c|c|c|c|c|c|c|}
\hline TEST TYPE & TEST" & SAMPLEE & DURATION & XR.H. & DATE IN & DATE OUT & $\underset{(g)}{\operatorname{MaSS}}$ & $\underset{(g)}{\text { MASS DUT, }}$ & $\left(\times 1 \oplus E-\dot{5}_{g}\right)$ & REMARKS & \\
\hline 165-95RH & $\begin{array}{l}v-101 \\
v-102 \\
v-103 \\
v-104 \\
v-105 \\
v-100\end{array}$ & $\begin{array}{l}181 \\
102 \\
103 \\
104 \\
105 \\
106 \\
197 \\
108 \\
190 \\
118 \\
111 \\
112\end{array}$ & $\begin{array}{c}20 \\
29 \\
29 \\
58 \\
56 \\
91 \\
91 \\
192 \\
192 \\
392 \\
365 \\
365 \\
1 N 0 E F \\
1 N O E F\end{array}$ & $\begin{array}{l}95 \\
95 \\
955 \\
95 \\
95 \\
95 \\
95 \\
95 \\
95 \\
95 \\
95 \\
95\end{array}$ & $\begin{array}{l}10 / 3 / 66 \\
16 / 3 / 86 \\
16 / 3 / 86 \\
16 / 3 / 98 \\
16 / 3 / 86 \\
16 / 3 / 86\end{array}$ & $3 / 9 / 87$ & $\begin{array}{l}0.1958 \\
8.1712 \\
6: 1873 \\
8.1679 \\
8.1827 \\
8.2818\end{array}$ & 0.1712 & - & Poteh of & ppt \\
\hline $131-95 R H$ & $\begin{array}{l}v-107 \\
v-108 \\
v-109 \\
v-110\end{array}$ & $\begin{array}{l}113 \\
114 \\
115 \\
118 \\
117 \\
118 \\
119 \\
128\end{array}$ & $\begin{array}{r}91 \\
91 \\
182 \\
182 \\
182 \\
385 \\
365 \\
3 \ldots 5 \\
\text { INDEEF }\end{array}$ & $\begin{array}{l}95 \\
95 \\
955 \\
95 \\
95 \\
95 \\
95 \\
95 \\
95\end{array}$ & $\begin{array}{l}10 / 3 / 80 \\
10 / 3 / 96 \\
10 / 3 / 96 \\
10 / 3 / 96 \\
10 / 3 / 80 \\
10 / 3 / 80\end{array}$ & $3 / 9 / 97$ & $\begin{array}{r}0.1962 \\
6.1589 \\
6.1892 \\
6.2701 \\
0.2468 \\
. .1880\end{array}$ & 0.1953 & 10 & Even dist & of Ppt \\
\hline 7609-95RH & $\begin{array}{l}v-111 \\
v-112 \\
v-113 \\
v-114\end{array}$ & $\begin{array}{l}121 \\
122 \\
123 \\
124 \\
125 \\
128 \\
127 \\
128\end{array}$ & $\begin{array}{c}91 \\
91 \\
192 \\
192 \\
365 \\
365 \\
365 \\
\text { INOEF } \\
\text { INDEF }\end{array}$ & $\begin{array}{l}95 \\
95 \\
95 \\
955 \\
95 \\
955 \\
95 \\
95\end{array}$ & $\begin{array}{l}16 / 3 / 86 \\
16 / 3 / 96 \\
16 / 3 / 86 \\
16 / 3 / 98 \\
16 / 3 / 86 \\
16 / 3 / 86\end{array}$ & $3 / 9 / 87$ & 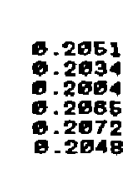 & $0.263 \%$ & 36 & & \\
\hline OBS-95RH & $\begin{array}{l}v-115 \\
v-110 \\
v-117 \\
v-118\end{array}$ & $\begin{array}{l}129 \\
136 \\
131 \\
132 \\
133 \\
134 \\
136 \\
136\end{array}$ & $\begin{array}{r}91 \\
91 \\
192 \\
192 \\
192 \\
365 \\
365 \\
305 \\
\text { INDEF } \\
\text { INDEF }\end{array}$ & $\begin{array}{l}95 \\
95 \\
95 \\
95 \\
95 \\
95 \\
95 \\
95\end{array}$ & $\begin{array}{l}10 / 3 / 86 \\
16 / 3 / 86 \\
10 / 3 / 86 \\
10 / 3 / 86 \\
16 / 3 / 86 \\
16 / 3 / 86\end{array}$ & $3 / 9 / 87$ & 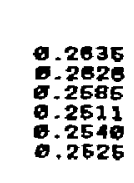 & 0.2828 & - & & \\
\hline BAS-95RH & $\begin{array}{l}v-110 \\
v-120 \\
v-121 \\
v-122\end{array}$ & $\begin{array}{l}137 \\
148 \\
139 \\
148 \\
241 \\
142 \\
143 \\
144\end{array}$ & $\begin{array}{r}91 \\
91 \\
192 \\
182 \\
385 \\
365 \\
365 \\
\text { INDEF } \\
\text { INDEF }\end{array}$ & $\begin{array}{l}95 \\
95 \\
95 \\
95 \\
95 \\
95 \\
95 \\
95\end{array}$ & $\begin{array}{l}10 / 3 / 98 \\
16 / 3 / 80 \\
10 / 3 / 88 \\
16 / 3 / 86 \\
10 / 3 / 86 \\
10 / 3 / 80\end{array}$ & $3 / 9 / 87$ & $\begin{array}{l}0.1997 \\
0.3684 \\
8.2313 \\
: .2439 \\
6.2796 \\
0.2311\end{array}$ & 0.1898 & -10 & & \\
\hline & & & & & Cont'd & & & & & & \\
\hline
\end{tabular}




\begin{tabular}{|c|c|c|c|c|c|c|c|c|c|c|}
\hline TEST TYPE & TEST & SAMPLE\# & $\begin{array}{l}\text { DURATION } \\
\text { (d) }\end{array}$ & & OATE IN & OATE OUT & $\underset{\text { (g) }}{\text { MASS IN }}$ & $\begin{array}{l}\text { MASs ouT } \\
\text { (g) }\end{array}$ & $(\times 10 E-5 g)$ & REMARKS \\
\hline IBE-BERH & $\begin{array}{l}v-123 \\
v-124 \\
v-125 \\
v-120 \\
v-127 \\
v-128\end{array}$ & $\begin{array}{l}145 \\
140 \\
147 \\
148 \\
149 \\
159 \\
151 \\
162 \\
163 \\
154 \\
165 \\
168\end{array}$ & $\begin{array}{r}28 \\
28 \\
58 \\
68 \\
66 \\
91 \\
91 \\
182 \\
182 \\
182 \\
365 \\
365 \\
\text { IGEF } \\
\text { IMDEF }\end{array}$ & 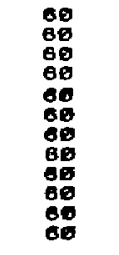 & $\begin{array}{l}10 / 3 / 86 \\
10 / 3 / 86 \\
16 / 3 / 86 \\
10 / 3 / 86 \\
16 / 3 / 86 \\
16 / 3 / 66\end{array}$ & $3 / 9 / 87$ & $\begin{array}{l}0.1983 \\
0.1832 \\
8.2683 \\
0.1973 \\
0.1845 \\
0.2042\end{array}$ & 0.1302 & -10 & \\
\hline $131-6 e R H$ & $v-129$ & $\begin{array}{l}157 \\
158\end{array}$ & $\begin{array}{l}182 \\
182\end{array}$ & $\underset{60}{60}$ & $\begin{array}{l}10 / 3 / 86 \\
10 / 3 / 86\end{array}$ & & $\begin{array}{l}0.1889 \\
0.1604\end{array}$ & & & \\
\hline $7008-60 R H$ & $v-130$ & $\begin{array}{l}158 \\
168\end{array}$ & $\begin{array}{l}182 \\
182\end{array}$ & 80 & $\begin{array}{l}16 / 3 / 86 \\
16 / 3 / 68\end{array}$ & & $\begin{array}{l}0.1735 \\
0.1984\end{array}$ & & & \\
\hline OBS- -OERH & $v-131$ & $\begin{array}{l}161 \\
162\end{array}$ & $\begin{array}{l}182 \\
182\end{array}$ & 60 & $\begin{array}{l}10 / 3 / 86 \\
16 / 3 / 86\end{array}$ & & 8.2454 & & & \\
\hline RAS-6ERH & $v-132$ & $\begin{array}{l}163 \\
164\end{array}$ & $\begin{array}{l}182 \\
182\end{array}$ & 60 & $\begin{array}{l}10 / 3 / 86 \\
16 / 3 / 86\end{array}$ & & :.2568 & & & \\
\hline N2S-80RH & $v-133$ & $\begin{array}{l}185 \\
186\end{array}$ & $\stackrel{g 1}{91}$ & 60 & & & & & & \\
\hline N3S-OERH & $y-134$ & $\begin{array}{l}187 \\
188\end{array}$ & $\stackrel{92}{82}$ & $6 \theta$ & & & & & & \\
\hline NAS-8ERH & $y-136$ & 168 & 91 & $\because 6$ & & & & & & \\
\hline NES-EORH & $v-136$ & $\begin{array}{l}172 \\
172\end{array}$ & 91 & 80 & & & & & & \\
\hline AG-OERH & $v-137$ & $\begin{array}{l}173 \\
174\end{array}$ & $\begin{array}{l}91 \\
91\end{array}$ & $\begin{array}{l}80 \\
80\end{array}$ & & & & & & \\
\hline
\end{tabular}




\begin{tabular}{|c|c|c|c|c|c|c|c|c|c|c|}
\hline TEST TYPE & TESTH & SAMPLE & $\begin{array}{l}\text { DURATION } \\
\text { (d) }\end{array}$ & * R.H. & DATE IN & DATE OUT & $\underset{\text { (g) }}{\operatorname{MASS}}$ & $\underset{(\mathbf{g})}{\operatorname{mass} \text { OUT }}$ & ( & REMARKS \\
\hline 185-10BRH & $\begin{array}{l}v-138 \\
v-139 \\
v-140 \\
v-141 \\
v-142 \\
v-143\end{array}$ & $\begin{array}{l}175 \\
176 \\
177 \\
178 \\
179 \\
186 \\
161 \\
182 \\
183 \\
184 \\
185 \\
186\end{array}$ & $\begin{array}{c}28 \\
28 \\
58 \\
68 \\
60 \\
91 \\
91 \\
182 \\
182 \\
365 \\
365 \\
365 \\
\text { INDEF } \\
\text { INDEF }\end{array}$ & $\begin{array}{l}108 \\
108 \\
108 \\
108 \\
108 \\
168 \\
168 \\
168 \\
168 \\
168 \\
168 \\
160\end{array}$ & $\begin{array}{l}10 / 3 / 86 \\
16 / 3 / 86 \\
10 / 3 / 86 \\
16 / 3 / 86 \\
16 / 3 / 86 \\
10 / 3 / 86\end{array}$ & $3 / 9 / 87$ & $\begin{array}{l}\text { E. } 1855 \\
6.2047 \\
8.1798 \\
6.1828 \\
0.1816 \\
\text { E. } 1975\end{array}$ & D. 1882 & 270 & Cond. H2O \\
\hline 131-16ERH & $V-144$ & $\begin{array}{l}187 \\
180\end{array}$ & $\begin{array}{l}182 \\
182\end{array}$ & $\begin{array}{l}180 \\
160\end{array}$ & $\begin{array}{l}16 / 3 / 80 \\
10 / 3 / 60\end{array}$ & & $\begin{array}{l}0.2603 \\
0.3948\end{array}$ & & & \\
\hline $7868-1008 \mathrm{RH}$ & $v-145$ & $\begin{array}{l}189 \\
198\end{array}$ & $\begin{array}{l}182 \\
182\end{array}$ & 100 & $\begin{array}{l}18 / 3 / 80 \\
16 / 3 / 86\end{array}$ & & $\begin{array}{l}0.2045 \\
0: 2208\end{array}$ & & & \\
\hline OOS-1EのRH & $V-140$ & $\begin{array}{l}191 \\
192\end{array}$ & $\begin{array}{l}182 \\
182\end{array}$ & $\begin{array}{l}190 \\
100\end{array}$ & $\begin{array}{l}\text { 10/3/80 } \\
16 / 3 / 86\end{array}$ & & $\begin{array}{l}0.2418 \\
6.2538\end{array}$ & & & \\
\hline BAS-16ERH & $v-147$ & $\begin{array}{l}183 \\
194\end{array}$ & $\begin{array}{l}182 \\
182\end{array}$ & 160 & $\begin{array}{l}10 / 3 / 48 \\
10 / 3 / 80\end{array}$ & & $\begin{array}{l}0.3852 \\
0.2107\end{array}$ & & & \\
\hline AB-1EERH & $v-148$ & $\begin{array}{l}195 \\
198\end{array}$ & $\begin{array}{l}182 \\
182\end{array}$ & $\begin{array}{l}100 \\
100\end{array}$ & & & & & & \\
\hline
\end{tabular}

- total assembly ma ss 
Water speciation studies of these glasses using step-heating-quadruple mass spectrometry techniques will be performed in collaboration with William Ebert (Section IV.C.).

\section{b. Other Analyses Planned}

Compositional (SEM/EOX, SIMS, nuclear reaction techniques) and mineralogical (optical microscopy, XRO, vibrational spectroscopy) characterization of glasses from all hydration runs will be performed. These data will fom the basis of the macroscopic description of glass/vapor interaction. The relative abundances of surface precipitated secondary products will also be documented.

$X$-ray scattering, MMR $\left(295 i, 27_{A 1}, 11_{B}\right.$, and $\left.17_{0}\right), I R$, and Raman techniques are potential methods that we plan to use to examine the surface structure of the hydration layer(s). The analytical objective here is to detect structural reorganization across the layer(s). These results will be correlated to the macroscopic data collected above. Laser Raman microprobe and IR techniques may also be employed in surface analyses of future in sity runs.

The analytical measurements described above will collectively form the basis of a detailed molecular description of the corrosion process. No comparable comprehensive analytical approach has been attempted by any laboratory for studying vapor corrosion of a glass surface, although individually, each analytical technique has been successfully used by our group and other workers in glass corrosion research for similar applications.

\section{Analog Experiment}

(QA level III, activity $10-20-29)$

The purpose of the analog experiment has been described previously [BATES-3]. Two analog experiments were run concurrently with the $\mathrm{N}-2$ Test series. One of these experiments was terminated after approximately one year and the other is ongoing. For each experiment, the solution that is collected after it has passed through the tuff core is analyzed for radionuclides. For the terminated experiment the core was disassembled and the components analyzed. The results are discussed in detall in the topical report, "Application of the NNHSI Unsaturated Test Procedure to 
Actinide Doped SRL 165 Type Glass." The conclustons were that the canister sections used in the analog experiment, al though heat treated at approxfmately $550^{\circ} \mathrm{C}$ for 24 hours, gave no evidence for sensitization and the reaction of the glass, as measured by the release of radioactive tracers ${ }^{121} \mathrm{Eu},{ }^{133} \mathrm{Ba}$, and $137 \mathrm{Cs}$, together with the amount of $237 \mathrm{~Np},{ }^{239} \mathrm{Pu}$, and $241_{\text {An }}$ associated with the metal waste form holder, and the (NL) wt $_{\text {, }}$ indicated a reaction after 52 weeks simflar to that noted for other tests or experiments run for 52 weeks in which the degree of metal/ss interaction was small.

\section{NNWSI GAMMA IRRADIATION TESTING \\ (QA level III, activity $\# D-20-30$ )}

\section{A. $\quad 2 \times 10^{5} \mathrm{R} / \mathrm{h}$ Experiments}

Results of experiments done at $2 \times 10^{5} \mathrm{R} / \mathrm{h}$ have been discussed previously [BATES-5] relating to the reaction of SRL glass. The results relating to the reaction of ATM-1C and ATM-8 glasses were compiled as an article submitted to the Journal of Materials Research and as a set of data tables to be published as a UCRL document. As a result of reviewer's comments, the article has $r$ en revised to incorporate new data. The revised article [BATES-6] and the accompanying data set [BATES-7] have been submitted to NNWSI for review. These reports provide the results and discussion of all experiments done using ATM-1C and ATM-8 glasses to assess the effect of radiation on glass reaction. An overview of these results is given below.

\section{Background}

One concern that has been ratsed previously in the literature is the uncertain effects of penetrating radiation on the performance of the waste form when in contact with groundwater. For NNWSI, the conditions anticipated for disposal suggest a priori that radiation should have little effect on the performance of the glass. Specifically, since the waste container is to maintain its integrity during the $300-1000$ year containment period, water will contact the glass only after the exposure rate in the repository has dropped to values of less than $50 \mathrm{R} / \mathrm{h}$. Also, since the NNWSI site hydrology is unsaturated, the opportunity for contact between 
standing water and glass will be remote. The most likely reactants would be humid air and glass, or small pockets of transient water and glass. The experiments described in this paper address the unlikely, but possible, case where relatively large volumes of liquid water contact glass, and measure the differences that occur in the glass reaction process as a function of exposure rate.

Previous studies [BARKATT, BURNS, McVAY-1] raise several issues that may affect the glass performance. These concerns include:

(1) What reactions occur when repository groundwater is subjected to gamma radiation in the presence of waste package components, and what is the ultimate effect on glass performance? It has been established [BURNS] that when humid air is subjected to gamma irradiation, nitric acid is produced in the gas phase. When a two-phase air-water system is irradiated, the nitric acid dissolves in the water, and may reduce the $\mathrm{pH}$ of the solution, attaining values as low as 3 . As the pH changes, if glass is present, the solubilities of glass components change, and the extent of glass reaction may thereby increase. It has been demonstrated [PLODINEC] that glasses are more reactile in high or low pH solutions, but quite resistant to reaction in neutral $\mathrm{pH}$ solutions.

(2) The radiolytic production of nitric acid in an air/water system increases with the exposure rate according to the relationship established by [BURNS],

$$
N=2 C_{0} R\left[1-\exp \left(-1.45 \times 10^{-5} \times 6 D t\right)\right]
$$

where

$N=$ the number of moles of $n i t r i c$ acid produced per system volume (moles/L),

$C_{0}=$ the initiaj nitrogen concentration in the gas phase (moles $/ L$ ),

$R=$ vol gas $_{\text {gol }}$ liq.

$G=$ the number of molecules of nitric acid produced when $100 \mathrm{eV}$ of radiation energy is absorbed by the nitrogen gas,

$D=$ exposure rate $(R / h)$, and

$t=t / m e$ of irradiation (h). 
Based on this formalism, it is tempting to suggest that if experiments were performed for a short time period using a large exposure rate, more nitric acid would be produced than with a smaller exposure rate, and some indication of projected performance at smaller exposure rates and longer time periods may be expected. It is of interest to determine whether experiments that attain the same total dose yield the same extent of glass reaction.

(3) According to $\mathrm{Eq}$. (1), the value of $\mathrm{R}$ will affect the concentration of nitric acid in solution. Since expected NNWSI repository conditions allow that $R$ may vary considerably, what is the functionality between $R$ and the extent of glass reaction, and can one value of $R$ be used to evaluate successfully repository behavior?

To address these concerns, NNWII has initiated an extensive series of experiments. These experiments include static leach tests of glasses of different compositions, performed for extended time periods and at different exposure rates $\left(2 \times 10^{5}, 1 \times 10^{4}, 1 \times 10^{3}\right.$, and 0 R/h) [BATES- 1 , $-2,-5]$. The glasses used in these experiments are based on formulations typical of those to be produced by the Defense Waste Processing Facility at Savannah River Laboratory (SRL), and formulations of a reference composition for reprocessed commercial waste. The reference commercial glasses have compositions similar to Pacific Northwest Laboratory (PNL) 76-6B glass, are designated ATM-1C and ATM-8 glasses, and are made by the Materiais Characterization center (MCC). While no glass from a commercial waste stream, other than that from the West Valley Demonstration Project (composition not similar to ATM-1C or ATM-8), is currently expected to be stored in the first repository, a large data base exists for the leaching of PNL 76-68 and the ATH glasses, and this data base may be useful in interpreting the present results. The rationale for studying different glass types is to determine the effect of radiation over as wide a range of conditions as possible. 
The results of the experiments on both SRL and the ATM glasses have been previewed [BATES-8], and the detalled procedures and results on the SRL glass thave been reported [BATES-2, -5$]$. An addendum has also been compiled, which contains the complete set of raw data and experimental conditions [8ATES-7].

At exposure rates of $2 \times 10^{5}$ and $1 \times 10^{3} \mathrm{R} / \mathrm{h}$, standing water could only come into contact with the glass if there were a premature breach in the containment. However, it was felt that a wide range of exposure rates offered the best opportunity to determine the effects of radiation.

\section{Discussion}

The experimental data and results are presented in [BATES-6, -7]. In this section the results of the solution and component analyses from each set of experiments are qualitatively compared to assess the effect of radiation on the glass reaction. Additionally, the data are compared to note the effect of varying the experimental parameters (rock' glass types) to the results of other MCC-1 type experiments done with similar glasses. Of the results obtained, the solution pH, behavior of the actinide elements and appearance of the surface and the reacted layer are most affected by varying the exposure rate of gamma irradiation, while the nomalized release of cations associated with glass reaction, e.g., the boron group of elements, $\mathrm{B}, \mathrm{Na}$, and $\mathrm{Mo}_{\mathrm{O}}$ and the depth of the reacted layer are nearly unaffected within the range of parameters studied.

\section{a. pH}

The $\mathrm{pH}$ values of the solutions in the blank experiments are more acidic when radiation is present. In both the $2 R$ and $I R$ experiments the blank solutions maintained $p H$ levels between 6 and 7 for the duration of the experiments. In the $2 R$ experiment a total dose of $3 \times 10^{8} R$ was reached after 56 days, while in the $1 R$ experiment $7 \times 10^{6} \mathrm{R}$ was reached after 278 days. The $\mathrm{pH}$ becomes acidic due to the formation of nitrogeneous acids, but in both cases the pH did not fall below 6.2 which is the level of the carbonate buffer. 
When glass is added, the leachate $\mathrm{pH}$ values trend more basic as the exposure rate becomes less. In the $2 R$ experiments the final pit values are about 7.4 after 56 days after ranging between 6.9 and 7.7 . While ATM-1C and ATM-8 glasses have different trends (discussed later), the ATM-8 trend is upward from a 7-day value of 6.9. In the IR experiments the pH values range to the mid- 7 level after starting in the high to mid-8 range. Without radiction the leachate $\mathrm{pH}$ values continually become more basic. This is a well-established trend in the reaction of nuclear waste glasses and is due to hydrolysis reactions of which the net result is to exchange cations in the glass with hydrogen tons from solution. When radiation is present the final leachate $\mathrm{pH}$ is a balance between the rate of formation of $n i$ trogeneous acids, the extent of glass reaction, and the buffering rapacity of the leachate. The rate of acid formation is essentially constant over the duration of the experiments for each exposure rate. The rate of glass reaction slows eventually in all experiments, although in the $2 R$ experiments the rate actually increases through 14 days before decreasing.

In the present set of experiments the results indicate that at $2 R$ the effect of radtation initially dominates the system and only after continued glass reaction does the $\mathrm{pH}$ become slightly more basic. At $1 R$ the effect of radiation is less and the glass reaction initially dominates the leachate pH. Only with continued radiation and slower glass reaction does the solution become more acidic. At $O R$ the system is dominated by the glass. While the solution $\mathrm{pH}$ is affected by the interplay between radiation and glass reaction, it is evident that the extraction of soluble components from the glass and the thickness, although not the composition, of the reaction layer is relatively independent of leachate $\mathrm{pH}$. This is rivteworthy because previous studies [PLODINEC] have found that glass reaction is usually less when the leachate is Duffered near $\mathrm{ph} 7$ while it is more rapid at higher and lower pH values.

\section{b. Actinide Release}

While the extent of glass reaction appears to be unaffected by the exposure rate, the amount of $\mathrm{U}_{1} \mathrm{Pu}$, and $\mathrm{Np}$ released from the glass and the behavior of these elements in solution is a strong function of exposure rate. The present results indicate that as the exposure rate increases and 
the effective solution pH decreases, the normalized release of each actinide element increases, the fraction of $N p$ and $P_{H}$ that passes through a $50 \mathrm{~A}$ filter increases, the fraction of $\mathrm{Np}$ and $\mathrm{Pu}$ sorbed to metal, tuff, or glass decreases, and the depletion of $U$ in the reacted glass layer increases. As the pH of the leachate decreases each actinide shows a greater propensity to remain associated with the solution either as a colloidal or non-filicerable fraction (Table 18), as opposed to a solid component. This is reasonable in that previous studies [KIM] indicate that the solubility of each of these elements increases with increased acidity in the range 6-10.

\section{c. Reacted Glass}

As the exposure rate becomes greater the nature and amount of reaction products on the glass surface and the composition of the reacted layer varies. In the $2 R$ experiments there is no butldup of $S T$ in the region of the reacted layer near the surface and the only reaction products are monazite (established by $x$-ray diffraction analysis); while in the $O R$ experiments there is a significant increase in $\$ i$ in the near-surface regivil and an associated increase in the density of the outer layer. A $\mathrm{Sr} /$ Ba phase appears immediately, there are large aggregates of $\mathrm{Fe}, \mathrm{Ca}, \mathrm{H}$, $U, S 1$, and $S$ and the amount of the monazite phase is greatly reduced.

In addition, the relative composition of the reaction layer varies as a function of exposure rate. In the $2 R$ experiments there is less $\mathrm{Ca}$ and $\mathrm{Al}$ remaining in the reaction layer and the nomalized release of these elements is greater than in the OR experiments. The observations made in this section are strangly correlated to the pH of the leachate. When the pH is more acidic, those elements whose solubilities show a strong $\mathrm{pH}$ dependence are released from the glass and the reaction layer and are found in solution. When the pH is more basic, these elements elther form insoluble aggregates on the reacted surface or are not released from the reacted layer. 


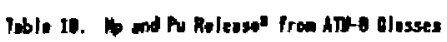

\begin{tabular}{|c|c|c|c|c|c|c|c|c|c|c|c|c|c|c|c|}
\hline \multirow[b]{2}{*}{ Test Ipp } & \multirow[b]{2}{*}{$\begin{array}{c}\text { Durntion } \\
\text { (0yy) }\end{array}$} & \multirow[b]{2}{*}{ pH } & \multirow[b]{2}{*}{$\begin{array}{c}\text { Radiation } \\
\text { Lerol } \\
\text { (RM) }\end{array}$} & \multicolumn{6}{|c|}{4} & \multicolumn{6}{|c|}{$f_{u}$} \\
\hline & & & & 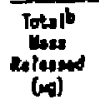 & $\begin{array}{l}\text { Filterex } \\
\text { Fraction } \\
\mathbf{y}\end{array}$ & $\begin{array}{l}\text { Solution" } \\
\text { Fraction }\end{array}$ & Fratel & $\begin{array}{l}\text { Detal } \\
\text { or Iuffl } \\
\text { Frection } \\
1\end{array}$ & $\begin{array}{l}\text { Filtered } \\
\text { Concenleation } \\
(m-a l e s / R]\end{array}$ & $\begin{array}{c}\text { Tetolb } \\
\text { Releused } \\
\text { (y) }\end{array}$ & $\begin{array}{l}\text { Filterex } \\
\text { Fraction } \\
\Sigma\end{array}$ & $\begin{array}{l}\text { Solution } \\
\text { Fruction } \\
y\end{array}$ & Fratetion & $\begin{array}{l}\text { Letal } \\
\text { or Iuff } \\
\text { Fraction } \\
\mathbf{t}\end{array}$ & $\begin{array}{l}\text { Fillered } \\
\text { Crucentration } \\
\text { (neoles/l) }\end{array}$ \\
\hline $\begin{array}{c}\text { Glase Disise } \\
\text { Ed-13 }\end{array}$ & $\begin{array}{c}7 \\
14 \\
28 \\
5\end{array}$ & $\begin{array}{l}8.8 \\
7.0 \\
7.4\end{array}$ & $2 \times 10^{5}$ & $\begin{array}{r}1.9 \\
10.2 \\
1.2\end{array}$ & $\lim _{\pi}^{10}$ & 10 & 4 & $\begin{array}{l}= \\
=\end{array}$ & $\begin{array}{l}1.6 \\
2.0 \\
2.4\end{array}$ & $\begin{array}{l}0.03 \\
. .24 \\
0.91\end{array}$ & $\begin{array}{l}15 \\
10 \\
12 \\
91\end{array}$ & $\begin{array}{l}11 \\
11 \\
20 \\
84\end{array}$ & $\begin{array}{l}04 \\
4 \\
4\end{array}$ & $=$ & 5 \\
\hline $\begin{array}{l}\text { Gleas Dits } \\
\text { E-13. Tulf }\end{array}$ & $\begin{array}{c}7 \\
14 \\
24 \\
50\end{array}$ & $\begin{array}{l}7.1 \\
7.2 \\
7.2 \\
7.8\end{array}$ & $2 \times 14^{5}$ & $\begin{array}{r}1.6 \\
5.6 \\
11.2 \\
12.5\end{array}$ & 1010 & $\underset{10}{\mathbf{1 0}}$ & $\begin{array}{c}0 \\
11\end{array}$ & 10 & 0.6 & $\begin{array}{l}0.01 \\
8.7 \\
.23 \\
8.28\end{array}$ & 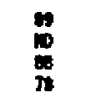 & $\begin{array}{l}4 \\
\text { tu } \\
10\end{array}$ & $\begin{array}{l}4 \\
04\end{array}$ & $\begin{array}{l}0 \\
0 \\
0\end{array}$ & $\begin{array}{c}2 \\
10 \\
5\end{array}$ \\
\hline $\begin{array}{l}\text { Crushod tisat } \\
\text { Eifis }\end{array}$ & $\begin{array}{c}7 \\
14 \\
20 \\
8\end{array}$ & $\begin{array}{l}6.8 \\
7.1 \\
7.4 \\
7.7\end{array}$ & $2 \times 10^{5}$ & $\begin{array}{r}0.9 \\
4.1 \\
11.3 \\
4.1\end{array}$ & $\underset{6}{6}$ & $\underset{10}{\mathbf{1 0}}$ & 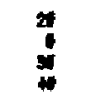 & $\begin{array}{l}- \\
-\end{array}$ & $\begin{array}{l}1.3 \\
1.4\end{array}$ & $\begin{array}{l}1.5 \\
. .5 \\
. .55 \\
0.52\end{array}$ & $\begin{array}{l}4 \\
10 \\
4\end{array}$ & $\begin{array}{l}5 \\
5 \\
1 \\
1\end{array}$ & $\begin{array}{l}\mathbf{x} \\
\mathbf{x} \\
\boldsymbol{\varpi}\end{array}$ & I & $\begin{array}{l}4 \\
5 \\
5\end{array}$ \\
\hline $\begin{array}{l}\text { G10:e Dist: } \\
\text { Eris }\end{array}$ & $\begin{array}{c}n \\
6 \\
11 \\
162 \\
270\end{array}$ & $\begin{array}{l}7.8 \\
7.8 \\
7.8 \\
7.0\end{array}$ & $1 \times 11^{3}$ & $\begin{array}{r}9.4 \\
5.5 \\
11.8 \\
0.8 \\
10.4\end{array}$ & $\begin{array}{l}4 \\
2 \\
4 \\
4 \\
20\end{array}$ & $\underset{*}{4}$ & $\begin{array}{l}10 \\
11 \\
11\end{array}$ & $\begin{array}{l}= \\
= \\
=\end{array}$ & 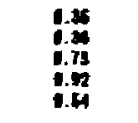 & $\begin{array}{l}1.0 \\
0.21 \\
0.22 \\
1.49\end{array}$ & $\begin{array}{l}14 \\
21 \\
22 \\
7\end{array}$ & $\begin{array}{l}4 \\
3 \\
1 \\
1 \\
1\end{array}$ & $\begin{array}{l}\mathbf{y} \\
y \\
y \\
y \\
y\end{array}$ & $\begin{array}{l}- \\
\bar{z} \\
=\end{array}$ & $\begin{array}{l}0.15 \\
.11 \\
.11 \\
.11 \\
. .6\end{array}$ \\
\hline $\begin{array}{l}\text { Clus Disk: } \\
\text { E-13 + Tuff }\end{array}$ & $\begin{array}{c}20 \\
\mathbf{8} \\
11 \\
162 \\
270\end{array}$ & $\begin{array}{l}0.2 \\
7.7 \\
7.8 \\
7.6 \\
8.8\end{array}$ & $1 \times 10^{3}$ & $\begin{array}{r}5.1 \\
1.7 \\
11.7 \\
13.0 \\
11.1\end{array}$ & $\begin{array}{l}4 \\
20 \\
\mathbf{4} \\
\mathbf{4} \\
31\end{array}$ & 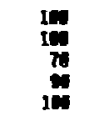 & $\begin{array}{l}0 \\
\mathbf{2} \\
10\end{array}$ & $\begin{array}{l}0 \\
1 \\
0\end{array}$ & $\begin{array}{l}\mathbf{1 . 4} \\
. .11 \\
1.1 \\
1.1 \\
0.0\end{array}$ & $\begin{array}{l}0.00 \\
0.20 \\
0.49\end{array}$ & : & $\begin{array}{l}2 \\
4 \\
2 \\
1 \\
1\end{array}$ & $\begin{array}{l}4 \\
11 \\
4 \\
4 \\
94\end{array}$ & $\begin{array}{l}5 \\
5 \\
5 \\
5\end{array}$ & 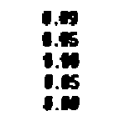 \\
\hline Clese Dides & $\begin{array}{l}14 \\
20 \\
50 \\
91\end{array}$ & $\begin{array}{r}8.0 \\
8.0 \\
9.2\end{array}$ & 1 & $\begin{array}{l}1.5 \\
.7 \\
1.8 \\
1.5\end{array}$ & $\begin{array}{l}3 \\
10 \\
4 \\
40\end{array}$ & $\begin{array}{l}\text { In } \\
\text { te } \\
\text { 194 }\end{array}$ & $:$ & $\begin{array}{l}\bar{z} \\
\overline{-}\end{array}$ & $\begin{array}{l}1.0 \\
0.10\end{array}$ & 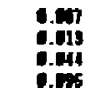 & $\begin{array}{l}27 \\
13 \\
33 \\
8\end{array}$ & $\begin{array}{l}5 \\
1 \\
2 \\
1\end{array}$ & $\begin{array}{l}\mathbf{5} \\
\mathbf{9} \\
\mathbf{9} \\
\mathbf{9 9}\end{array}$ & $\begin{array}{l}- \\
- \\
-\end{array}$ & $\operatorname{lin}_{10}$ \\
\hline $\begin{array}{l}\text { Glose Didh } \\
\text { EL-13 - Tuff }\end{array}$ & $\begin{array}{l}14 \\
20 \\
68 \\
91\end{array}$ & $\begin{array}{l}0.1 \\
8.4 \\
8.6 \\
8.7\end{array}$ & - & $\begin{array}{l}1.0 \\
2.1 \\
2.3 \\
2.3\end{array}$ & $\begin{array}{l}4 \\
10 \\
70 \\
51\end{array}$ & $\begin{array}{l}10 \\
104 \\
104\end{array}$ & $:$ & : & $\begin{array}{l}1.12 \\
6.9 \\
0.18 \\
0.31\end{array}$ & $\begin{array}{l}0.011 \\
0.18 \\
0.71 \\
0.112\end{array}$ & $\begin{array}{l}5 \\
10 \\
17 \\
22\end{array}$ & $\begin{array}{l}5 \\
2 \\
1 \\
1\end{array}$ & $\begin{array}{l}11 \\
92 \\
93 \\
95\end{array}$ & $\begin{array}{l}14 \\
6 \\
4\end{array}$ & 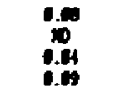 \\
\hline
\end{tabular}

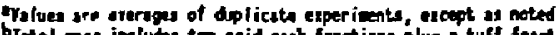

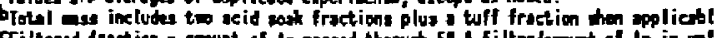

ciltered fraction = amount of $A n$ passed throuph be A filter/sount of to in enfiltered wolution.

dim A lilkers user insted of SI.

Phant of in associated rith tutf/total in relesese.

Divif miter.

Do - Mot deternined. 


\section{d. Parameter Effects and Comparison with Other Results}

In all sets of experiments the ATH-8 glass reacts more slowly than the ATM-1C glass, and there is no strong trend for the glass reaction to be retarded in the presence of tuff, despite the observation that $\mathrm{SI}$ concentrations are usually slightly larger with tuff present. Both of these observations are unexpected.

The retarded reaction of ATM- 8 glass is most 11 kely due to the compositional differences described earlier. Note the release of $A l$ in the ATM-8 experiments is usually decredsed substantially more than for the $B$ group of elements. Additionally, $i n$ the $2 R$ experiments there could be some effect as a result of the different starting surface texture of the glass, e.g., the ATM-8 glass have fewer fractures which could have resulted in less initial fracture reaction. However, the crushed ATM- 8 glass also had slower reaction than ATM-1c glass, which suggests surface texture is not the main contributing effect.

The inclusion of tuff or sllicate containing sources in an experimental design often retards the reaction of glass. In the present set of experiments there is no statistical difference in the no-tuff/tuff 2R results, a marked increase in release for the tuff-containing $I R$ experiments, and small but analytically significant increase in the tuffcontaining OR experiments for ATM-8 glass and a small decrease for ATM- $1 \mathrm{C}$ glass. The most striking difference (no-tuff vs. tuff) in solution compositions and glass reaction is that without tuff $A$ il is extracted from the leachate in all sets of experiments, while with tuff there is a measurable release of Al from the glass. This suggests that Al, in addition to 51 , may also play a role in controlling glass reaction.

The present results can be compared only indirectly to other results obtained using glasses of similar compositions because the experimental conditions (SA $N$, water composition, exiserimental components) have not been duplicated between the different groups of experiments. Accordingly, the range of normalized releases obtained in the present experiments fall with the values obtained by [MCVAY-2] $\left(90^{\circ} \mathrm{C}, S A / V=\right.$ $0.1 \mathrm{~cm}^{-1}, \mathrm{~J}-13$ water, tefion vessels, no radiation) for the boron group (56 days, $(\mathrm{NL})_{B} \simeq 23 \mathrm{~g} / \mathrm{m}^{2}$ ); are considerably less than observed by [LOKKEN] $\left(90^{\circ}\left\llcorner, S A / N=0.1 \mathrm{~cm}^{-1}\right.\right.$, silicate water, teflon vessels, no radiation) where 
$(\mathrm{NL})_{B} \cong 60 \mathrm{~g} / \mathrm{m}^{2}$ after 56 days; and are greater than obtained by [BAZAN] $\left(90^{\circ} \mathrm{C}, E J-13\right.$ water, tuff vessels, no external radiation) where $(\mathrm{NL})_{B} \cong 1$ $\mathrm{g} / \mathrm{m}^{2}$ after 90 days. The range of results obtained by different experimenters emphasizes the importance of the direct comparison of radiation effects made in the present results.

\section{Conclustons}

A serles of leach experiments have been done at varlous exposure rates of penetrating garmala radiation using saturated NWWSI repository conditions and two different ATM glass types. These experiments demon-

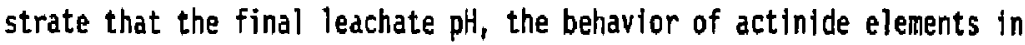
solution, and the nature of the reacted glass surface and associated reaction layer vary as a function of exposure rate, but that for the duration of comparable experiments through 56 days, the release of soluble glass components $(\mathrm{B}, \mathrm{MO}, \mathrm{Na})$ is relatively insensitive to the experimental conditions.

These observations suggest that (1) the performance of glass in a repository under conditions of water intrusion will be affected by the exposure rate over the lifetime of the repository, but that the nature of the effect will depend on the temporal interplay between radiolysis, groundwater, and glass reaction products. This interplay cannot be accelerated by simply increasing the exposure rate because, with the other parameters remaining constant, this increases the production of radiolysis products while unnaturally disturbing the balance of the system; and (2) the ratio between the solution volune and the gas avallable for reaction could be an important factor in affecting glass reaction and the release of radionuclides. This is beciuse as this ratio becomes larger, as is anticipated under unsaturated NNWSI repository conditions, the radiolysis products would become more concentrated. One would project that in a static or nearly static system, if the exposure rate and nitric acid production were large enough, the buffering capacity of the glass and the groundwater would be overcome, the pH would be driven more acidic, and acceleraced glass reaction may occur, as has been observed in DIW [BARKATT, McVAY-1]. Additional work to resolve this point is in progress. 


\section{B. $1 \times 10^{4} \mathrm{R} / \mathrm{h}$ Experiments}

The topical report describing the FY 1985 results has completed ANL editorial review and has been sent to NNWSI for technical review. Additional effort is being spent analyzing the tests that were done at $R$ values other than $\sim 3$ to see if the mechanism of reaction is affected by the increased gas volume and decreased liquid in contact with the glass.

\section{C. $1 \times 10^{3}$ and $0 \mathrm{R} / \mathrm{h}$ Experiments}

Experiments were performed during FY 1986 in radiation fields of $1 E 3 \mathrm{R} / \mathrm{h}$ and $0 \mathrm{R} / \mathrm{h}$. Glass formulations used inciuded actinide-doped SRL 165 type frit and ATM-2C and ATM-8 glasses. Work this period has centered on analyzing the reacted glass samples generated by these static leaching experiments. The samples are being analyzed with the purpose of identyfying secondary products and alteration products on the glass surfaces, determining depletion-depths and concentration profiles normal to the reacted surface, and measuring the extent of reaction using these depletion depths. While many analyses have been completed, a discussion of the results is not ready at this time. An overview of the analyses performed and the results obtained to date including some specific examples and a description of the analyses along with which analyses have been performed on which samples will be presented instead.

An important gauge of the extent of the glass reaction, as measured by changes in the glass Itself, has been presented previously as the glass weight change. As the surface of the glass dissolves (etches), or as ion exchange occurs, the glass weight changes. Etching will cause the glass weight to decrease, as will, in most cases, ion exchange. Precipitation of secondary products back onto the glass will cause the glass weight to increase. Only in the unlikely event where products precipitate out of the leachant onto the glass before significant glass reaction occurs will the glass weight increase upon reaction. Typlcally the glass will lose weight with reaction time as the surface etches and/or ion exchange occurs then gain weight as the leachate becomes saturated and precipltates form on the glass surface. The net weight change is, therefore, a balance between 
weight loss due to dissolution and weight gain due to precipitation. A correlation between the leachate data and the presence or absence of precipitates is expected to be found with the net glass weight change results.

Scanning electron microscopy (SEM) with associated energy dispersive $x$-ray spectroscopy (EDS) was used to locate and analyze the composition of preclpitates on the reacted glass surfaces. [Laser Raman microscopy (LRM) is currently being developed in order to characterize these precipitates structurally, as discussed later in the semiannual report, see Section IV.B]. Figure 10 shows a photomicrograph of a precipitate that formed during the nonirradiated leaching of many SRL $U$ glasses. The accompanying EQXS spectrum shows the precipitate to contain calcium, chloride, iron, manganese, and silicon. Some of the reacted glasses had a very large number of these precipitates on the surface. The precipitates are about $10 \mu m$ in cross-section and so will be prime candfdates for LRM analysis at a later date.

Some of the reacted glass samples were cut into cross-sections using a diamond wafering blade. The cross-sections were polished to a smooth finish using a $0.3 \mu$ alumina slurry. These cross-sections were carbon coated to a uniform thickness of $200 \AA$ to eliminate charging and were examined using the SEM. The region near the reacted surface is depleted in leachable cations, such as sodium, and has a lower density than the unreacted glass. The scattering cross-section in this depletion region is less than that in the unreacted glass and so both backscattered and secondary electron fmages can distinguish the depleted region as a darker area. The thickness of the depleted region depends on the extent of the glass reaction. Because of the possibility of etching, the depletion region thickness is a lower limit of the extent of reaction. Figure 11 shows a photomicrograph of a typical cross-section image. The darkest area on the right-hand side is the mounting resin. The area on the left-hand side is the unreacted glass and the intermediate regton is the depletion region. A thin area between the depletion region and the resin can be seen in some cross-sections which corresponds to the secondary phases and alteration phases on the very surface of the glass. The depletion region is usually much thicker than the surface phases. The depletion region 


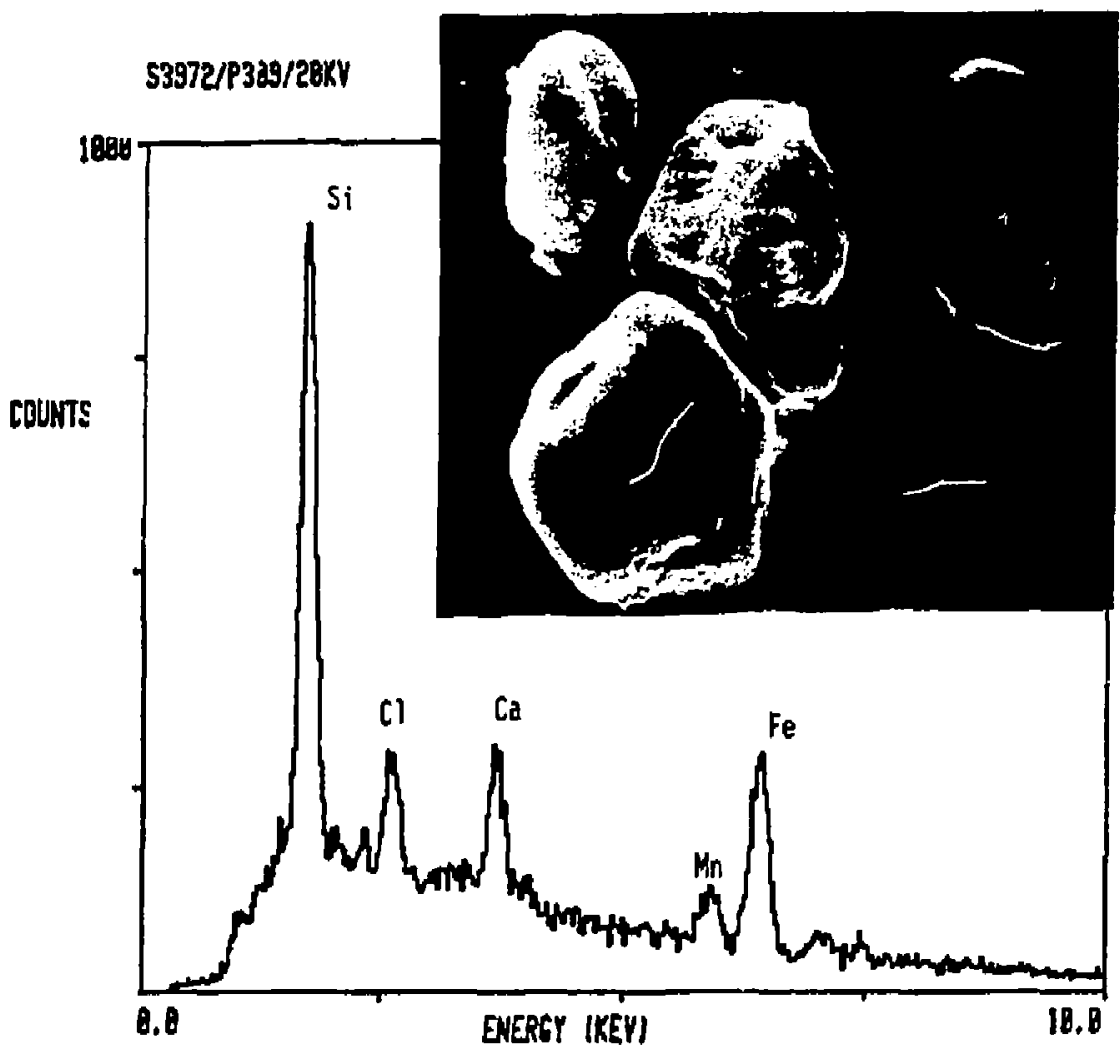

Fig. 10. Photomicrograph and EDS Spectrum of Precipitate Formed on SRL U Glass. Sample no. 397 reacted $181 \mathrm{~d}$ in EJ-13 water at $90^{\circ} \mathrm{C}$, $0 \mathrm{R} / \mathrm{h}$. The micrograph was taken using secondary electrons with a nlagnification of $1000 x$. 
shown in Fig. 11 can be seen to be rather nonuniform in thickness. This is because of the influence of the surface topology. The glasses crosssectioned were all reacted with "as-cut" surface finishes, which is equivalent to about a 320 grit finish. The glasses often have deep cracks normal to the reacted surfaces. These cracks are highly reactive, often more reactive than the outer surfaces. Their high reactivity may be due to localized $\mathrm{pH}$ excursions within the cracks to values higher than are possible at the outer surfaces which are in contact with the buffering leachate. After long reaction times the depletion layer may extend deep enough into the sample to engulf the cracks.

Concentration profiles have been obtained by scanning the electron heam laterally across the depletion zone while monitoring the EDS intensity at energies of interest. The beam may be stepped in very small increments and probe regions from the unreacted interior of the glass, the depleted region, and surface phases, if present. Such "depth profiles" provide information regarding the leaching characteristics of the glass as well as the extent of the reaction. Analysis of preclpitates present in the crosssection is semi-quantitative because of the smooth surface finish that can be obtained. (Analysis of secondary phases obtained by analyzing nomal to the reacted surface is not quantitative because of the rough surface topology of the sample. Rough surfaces do not generate spectra useful for quantitative analyses, al though they are useful as qualitative results.)

The line drawn across the center of the photomicrograph indicates the beam path of the analysis. The line profile of silicon in Fig. 11 shows high concentrations at points in the unreacted glass (left-hand side of spectrum and photomicrograph). The depletion region (center) has a lower silicon concentration than the unreacted glass and the resin has no silicon. Depletion regions generally showed lower silicon concentrations than the unreacted glass. This may result from differing $x$-ray generating efficiencies in the two regions rather than true concentration difference. The line profile for sodium has been multiplied by a factor of 20 in the figure for conventence in comparing the sodium behavior to that of silicon. Sodium, like stlicon, shows a lower concentration in the depletion region than in the unreacted glass. The sodium concentration apparently increases at the interface between the depleted region and the resin. Care must be 


\section{L497/2QKY}

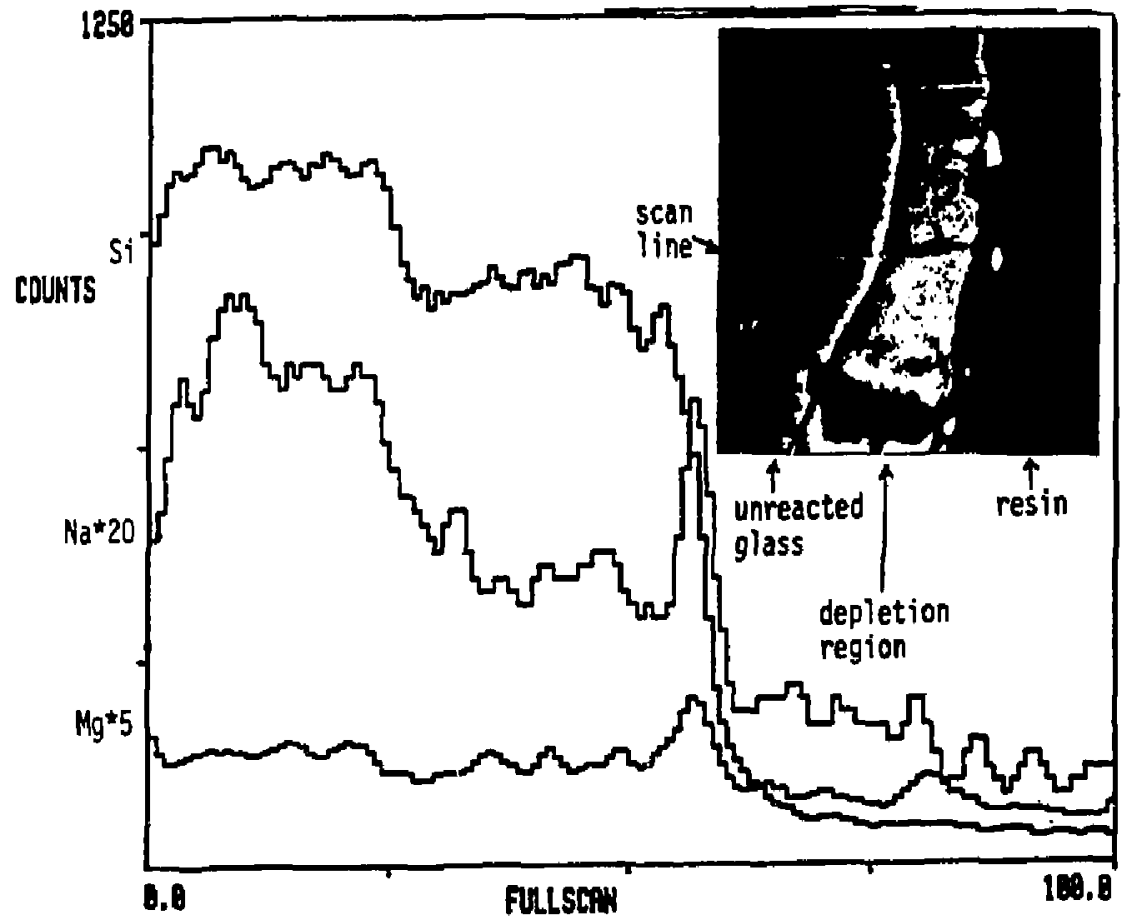

Fig. 11. Photomicrograph and EOS Line Profile of Cross Section of ATM-1C Glass. Sample no. 487 reacted $91 d$ in EJ-13 water at $90^{\circ} \mathrm{C}$, $1 E 3 \mathrm{R} / \mathrm{h}$. The micrograph was obtained using backscattered electron imaging and the magnification is $500 \mathrm{x}$. 
taken in evaluating the sodium profile because other elements have $x$-ray emissions at energies very near that of sodium, for example, copper and zinc. A complete spectrum must be collected to detect the higher energy lines of these other metals in order to identify the law energy peak properly. Further analysis showed the peak to be sodium. Sodium is also notorlous for migrating across or into the surface upon exposure to electron or ion beams. Magnesium was also found to be enriched in the surface layer (or precipitate). Notice finally the decrease in intensity of the silicon and sodium lines at the far left edge of their profiles. This results from the electron beam residing longer at the first spot analyzed and burning a small hole in the glass. (This is evident in the actual photo but not in the reproduction.) The $x$-ray yield in such holes is lower than in the pollshed flat regions.

As mentioned earljer, the depleted regions near the surface have a lower backscattering density than tho unreacted glass. This density difference has been analyzed semi-quantitatively using the "C.A.R.D." system which is integrated with the backscattered electron detector. [CARD is an acronym for Compositional Analysis using the Robinson (backscatter) Detector.] Such analysis is based on the fact that the fraction of the incident electron beam that is backscattered depends on the backscattering cross-section of the region probed, which increases monotonically (though not linearly) with the average atomic number of the sample in that region. For example, pure germanium $(z=32)$ has a highier backscattering crosssection than pure silicon $(z=14)$. Titanlum, vanadium, and chromium ( $z=22,23$, and 24 , respectively) have backscatter cross-sections that are about half way between silicon and germanium. Sodium chlorlde has a backscatter cross-section about the same as silicon, and has an average atomic number of 14 . The CARD analysis technique is useful in identifying elements not directly analyzable using EDS, such as $L I, B$, and 0 . By analyzing the sample for EDS detectable elements and for CARD backscatter intensity, one can gauge the amount of nondetectable elements in the sample by the difference between the intensity expected from the detectable elements and the measured intensity. Coupled with other techniques, such as wavelength dispersive $x$-ray spectroscopy, which is sensitive to boron and oxiggen, the amount of nondetectable elements such as lithium may be deduced by difference. 
Uncertainties remain in use of the CARD system is a quantitative tool, mainly because the relationship between the backscattered cross-section and the average atomic number is not linear. We do not yet have access to the exact functional dependency, and cannot accurately compute the backscatter cross-sections of complex samples. Nevertheless, the CARD analysis does afford a quantiflable measure of the samples backscattering power.

Another technique that we have used to determine the concentration profiles of the glass constituents normal to the reacted surface is secondary ion mass spectrometry (SIMS). This analysis provides concentration information on all elements, although hydrogen data is nonquantitative because of the high hydrogen gas background in our system, and we analyze only for positive species. SIMS analysis only occurs on species sputtered from the surface at the moment of analysis. By continuousiy sputtering in the same spot, the sample is eroded and analysis is made on a fresh surface that is progressively deeper into the sample. By monitoring the concentration of a given species as a function of time, a depth profile is generated. Figure 12 shows a typical elemental profile. The ordinate is the elemental intensity normalized to the silicon intensity at nearly the same depth in the sample. By normalizing to an element of assumed constant concentration, instrumental effects are effectively eliminated. The abscissa is in terms of time as data is collected periodically for elements of interest. Assuming a constant sputtering rate (which is an assumption we have yet to verify), the time axis is also proportional to depth. Preliminary determInation of the sputter rate using unreacted SRL 165 glass gave a rate of about $200 \mathrm{Am} / \mathrm{n}^{-1}$ at $4 \mathrm{kV}$ acceleration of a $\mathrm{Ar}^{+}$primary beam. A one micron thick depletion layer will be sputtered through within one hour at this rate. The layer thickness is defined by the inflection point of the sigmoidal profiles, which occurs after 32 misutes of sputtering (scan 45 ) in the sample shown in Fig. 12. The layer thickness for this sample is about $0.64 \mu \mathrm{m}$.

Glass samples that were doped with transuranic radfonuclydes have not been analyzed using the SIMS instrument. Instead, they are being analyzed using an fon microprobe instrument (which operates 01 the same basis as the SIMS instrument) which has been used previously to analyze radioactive samples. No results from these analyses are yet avallable. 


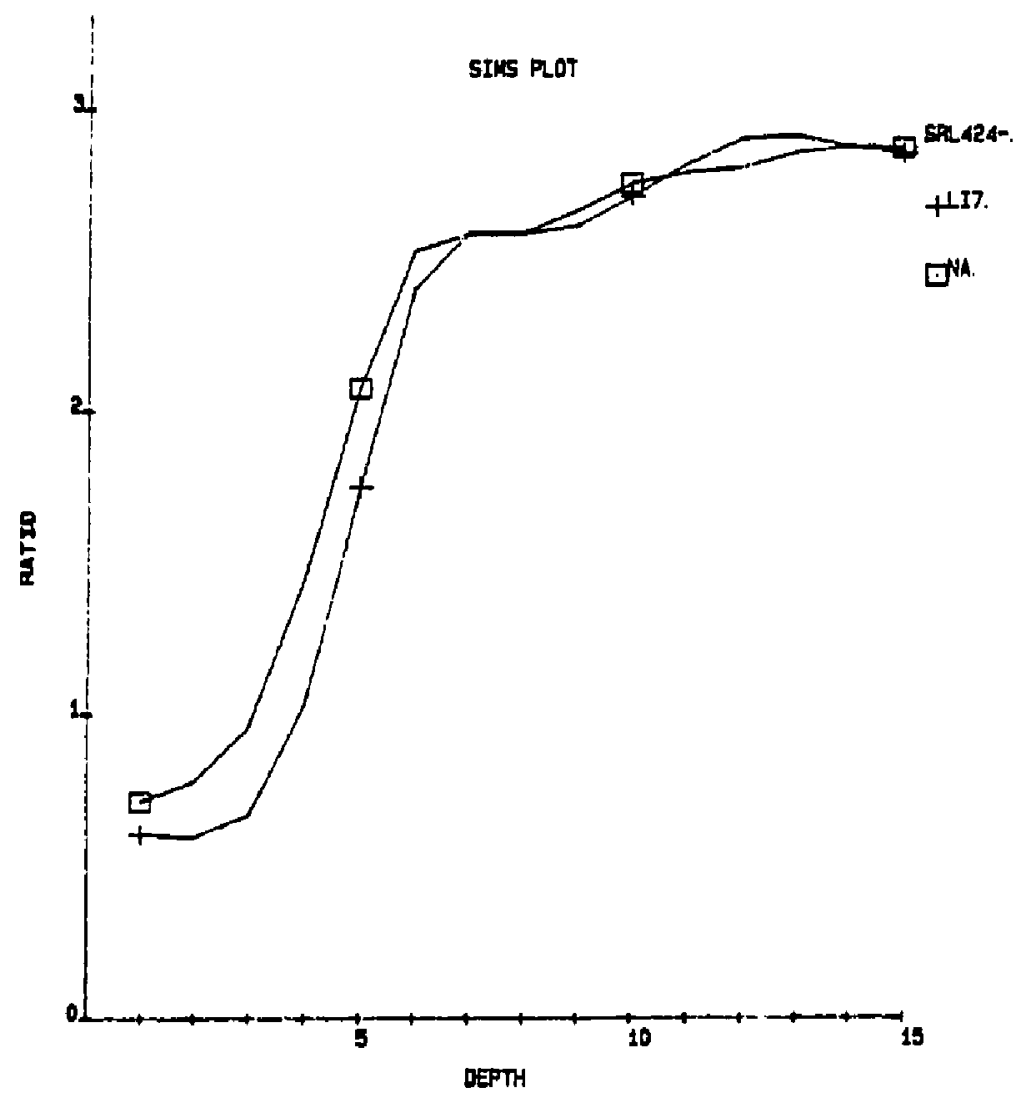

Fig. 12. SIMS Proftle of $7 \mathrm{Li}^{+}$and $23 \mathrm{Na}^{+}$from Sample 423, Experiment Number 6-361, SRL $U+$ tuff, $0 \mathrm{R} / \mathrm{h}, 80 \mathrm{~d}$. The scan numbers shown on the $x$-axis were obtained at elght minute intervals with scan $\# 1$ obtained at time zero. 
A separate technique used to analyze the concentration profile of hydrogen in the surface region is resonant nuclear reaction spectroscopy (RNRS). In this technique, the sample is bombarded with a very high energy nitrogen ion beam ( $>6 \mathrm{MeV}$ ). The sample attenuates the beam energy as the beam penetrates the sample. A nuclear reaction occurs between hydrogen atoms and nitrogen lons of a specific energy to produce a photon of energy. This photon has energy in the gamma range and escapes the sample unattenuated. By detecting this gamma photon and calculating the attenuating power of the sample, the concentration of hydrogen as a function of depth in the sample can be obtained. This information, in conjunction with depth profiles of alkali ions (especlally sodium and 1/thium), can be used to characterize further the extent of Ion exchange in the depleted region. To date only a few samples have been analyzed (by F. Ryerson, LLNL). An exemplasy profile is shown in Fig. 13. The attenuating power of the glass is about $2 \mathrm{MeV} / \mu \mathrm{m}$ (F. Ryerson, private communication). The depletion region thicknesses suggested by these RNRS results do not agree well with those suggested by the SIMS, SEM, or leachate results. This discrepancy has yet to be resolved.

Table 19 summarizes the analyses performed (or to be performed) on the samples generated by the FY 1986 Gama Irradiation Experiments. A complete compilation of the surface analytical results will be presented in the near future with a discussion of the entfre Fy 1985 experimental program.

\author{
IV. SURFACE ANALYTICAL SUPPORT \\ (QA Tevel III, activity $\$ 0-20-31$ )
}

\title{
A. SIMS Software
}

Reprograming of the data acquisition and data handiling codes has been postponed. Plans call for replacing the computer currently used for data acquisition with an Apple IIgs which can collect much more data without the delays necessary with the present computer system. A better representation of the profile will be possible with the greater speed and memory capabilities of the Apple Ilgs. The new acquisition computer is expected to be in place by fall 1987 whereupon a new acquisition code will be written to take advantage of the advanced capabilities. 


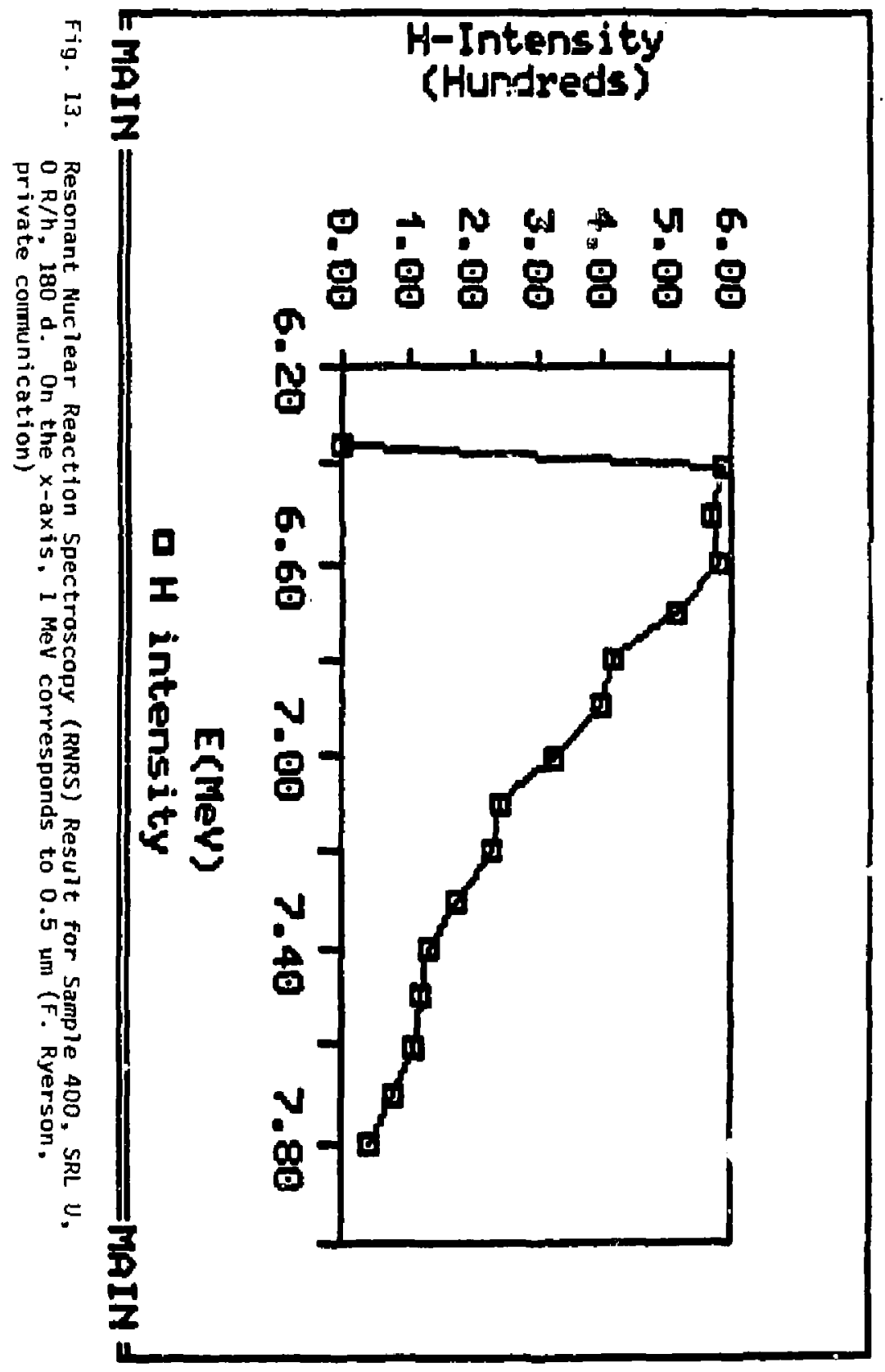


Table 19. List of Samples Analyzed using Various Surface Aralytical Techniques

\begin{tabular}{|c|c|c|c|c|c|}
\hline Exp't Type & $\begin{array}{l}\text { Exp't Jime } \\
\text { (days) }\end{array}$ & SEY/EDS & SIMS & RNRS* & IMP \\
\hline $\begin{array}{l}\text { SRL } U \\
\text { IF.3 R/h }\end{array}$ & $\begin{array}{r}28 \\
56 \\
91 \\
181 \\
278\end{array}$ & $\begin{array}{l}301 \mathrm{~V} \\
305 \mathrm{~V} \\
311 \mathrm{~V} \\
313 \mathrm{~V} \\
317 \mathrm{~V}\end{array}$ & $\begin{array}{l}302 \sqrt{ } \\
306 \mathrm{~V} \\
310 \mathrm{~V} \\
314 \mathrm{~V} \\
318 \mathrm{~V}\end{array}$ & $\begin{array}{c}304 \\
308 V \\
- \\
316 \\
320\end{array}$ & \\
\hline $\begin{array}{l}\text { SRL } U+\text { Tuff } \\
\text { IEJ } R / h\end{array}$ & $\begin{array}{r}28 \\
56 \\
91 \\
181 \\
278\end{array}$ & $\begin{array}{l}323 \mathrm{~J} \\
325 \mathrm{~V} \\
331 \mathrm{~V} \\
335 \mathrm{~V} \\
337 \mathrm{~V}\end{array}$ & $\begin{array}{l}324 \mathrm{~V} \\
326 \mathrm{~V} \\
332 \mathrm{~V} \\
336 \mathrm{~V} \\
338 \mathrm{~V}\end{array}$ & $\begin{array}{l}322 \\
328 \\
330 \\
334 \\
340\end{array}$ & \\
\hline $\begin{array}{l}\text { SRL A } \\
1 E 3 \mathrm{R} / \mathrm{h}\end{array}$ & $\begin{array}{r}28 \\
56 \\
91 \\
181 \\
278\end{array}$ & $\begin{array}{l}343 \\
347 \\
351 \\
353 \\
357\end{array}$ & & & $\begin{array}{l}344 \\
348 \\
352 \\
354 \\
358\end{array}$ \\
\hline $\begin{array}{l}\text { SRL A + Tuff } \\
\text { IE3 R/h }\end{array}$ & $\begin{array}{r}28 \\
56 \\
91 \\
181 \\
278\end{array}$ & $\begin{array}{l}361 \\
365 \\
369 \\
373 \\
377\end{array}$ & & & $\begin{array}{l}362 \\
366 \\
370 \\
374 \\
378\end{array}$ \\
\hline $\begin{array}{l}S R L U \\
0 R / h\end{array}$ & $\begin{array}{r}14 \\
28 \\
56 \\
91 \\
181 \\
278\end{array}$ & $\begin{array}{l}383 \checkmark \\
385 \checkmark \\
389 \checkmark \\
393 \checkmark \\
397 \checkmark \\
403 \checkmark\end{array}$ & $\begin{array}{l}384 \mathrm{~V} \\
386 \mathrm{~V} \\
390 \mathrm{~V} \\
394 \mathrm{~V} \\
398 \mathrm{~V} \\
402 \mathrm{~V}\end{array}$ & $\begin{array}{l}384 \\
388 \\
392 \checkmark \\
396 \\
400 \checkmark \\
404 \checkmark\end{array}$ & \\
\hline $\begin{array}{l}\text { SRL U + Tuff } \\
0 \mathrm{R} / \mathrm{h}\end{array}$ & $\begin{array}{r}14 \\
28 \\
56 \\
91 \\
181 \\
278\end{array}$ & $\begin{array}{l}405 v \\
409 \checkmark \\
413 v \\
419 \checkmark \\
423 v \\
425 \checkmark\end{array}$ & $\begin{array}{l}406 \mathrm{~V} \\
410 \mathrm{~V} \\
414 \mathrm{~V} \\
420 \\
42+\mathrm{V} \\
428\end{array}$ & & \\
\hline $\begin{array}{l}\text { SRL A } \\
0 R / h\end{array}$ & $\begin{array}{r}14 \\
28 \\
56 \\
91 \\
181 \\
278\end{array}$ & $\begin{array}{l}431 \\
433 \\
439 \\
441 \\
445 \\
449\end{array}$ & & & $\begin{array}{l}432 \\
434 \\
440 \\
442 \\
446 \\
450\end{array}$ \\
\hline
\end{tabular}


Table 19 (Cont'd)

\begin{tabular}{|c|c|c|c|c|c|}
\hline Exp't Type & $\begin{array}{l}\text { Exp't Time } \\
\text { (days) }\end{array}$ & SEM/EDS & SIMS & RNRS $^{*}$ & IMP \\
\hline $\begin{array}{l}\text { SRL A + Tuff } \\
0 R / h\end{array}$ & $\begin{array}{r}14 \\
28 \\
56 \\
91 \\
281 \\
278\end{array}$ & $\begin{array}{l}453 \\
459 \\
461 \\
465 \\
469 \\
473\end{array}$ & & & $\begin{array}{r}454 \\
460 \\
462 \\
\vdots \\
\vdots\end{array}$ \\
\hline $\begin{array}{l}\text { ATH-1c } \\
1 E 3 \mathrm{R} / \mathrm{h}\end{array}$ & $\begin{array}{r}28 \\
56 \\
91 \\
181 \\
278\end{array}$ & $\begin{array}{l}479 \checkmark \\
483 \checkmark \\
487 \checkmark \\
489 \checkmark \\
493 \checkmark\end{array}$ & $\begin{array}{c}480 \\
484 \\
- \\
- \\
-\end{array}$ & & \\
\hline $\begin{array}{l}\text { ATM-1c + Tuff } \\
\text { IE3 k/h }\end{array}$ & $\begin{array}{r}28 \\
56 \\
91 \\
181 \\
278\end{array}$ & $\begin{array}{l}497 \checkmark \\
501 \sqrt{ } \\
505 \checkmark \\
509 \checkmark \\
513 \checkmark\end{array}$ & $\begin{array}{c}500 \\
50 ? \\
- \\
- \\
=\end{array}$ & & \\
\hline $\begin{array}{l}\text { ATM-8 } \\
\text { IE3 R/h }\end{array}$ & $\begin{array}{r}28 \\
56 \\
91 \\
181 \\
278\end{array}$ & $\begin{array}{l}517 \\
521 \\
525 \\
529 \\
533\end{array}$ & & & $\begin{array}{c}518 \\
522 \\
- \\
- \\
-\end{array}$ \\
\hline $\begin{array}{l}\text { ATM-8 } \\
\text { IE3 R/h }\end{array}$ & $\begin{array}{r}28 \\
56 \\
91 \\
181 \\
278\end{array}$ & $\begin{array}{l}537 \\
541 \\
545 \\
549 \\
553\end{array}$ & & & $\begin{array}{c}538 \\
542 \\
- \\
- \\
-\end{array}$ \\
\hline
\end{tabular}

*Analyzed by F, Ryerson (LLNL).

checked analyses have been completed. 


\section{Establishment of a Laser Raman Microprobe Fac1lity}

The argon ton laser has been repalred and returned. Its performance has been deemed satisfactory and it has been reincorporated into the system. The new photon counter (EG\&G model 1209) has been tested and integrated into the system. Presently spectra of known samples are being collected to reoptimize the system. An exemplary spectrum of $\mathrm{CaCO}_{3}$ is shown in Fig. 14. Notice that the logarithm of the Intensity is plotted on the $y$-axis. The peak at $18363 \mathrm{~cm}^{-1}$ is a typical carbonate peak with a Raman shift measured to be $1117 \mathrm{~cm}^{-1}$. The signal-to-noise ratio is very sensitive to the sample topology. Figure 14 shows a worst case, though we feel that there is still room for improvement in the signal-to-noise ratio.

We have also been preparing for computer acquisition and treatment of the data. Students have been hired to operate the LRM and develop the computer software this summer.

\section{Development of a Gas Analysis System}

A gäs analysis system has been developed around a quadrupole mass analyzer (UTI model 100C). Gases may be leaked in directly from a sample ballast, evolved from solution, or desorbed from a solid. The last experiment is referred to as temperature programmable desorption wherein the solid sample is heated at a constant rate while the evolving spectes are continuousiy monitored. Current work deals with this technique.

A programmable temperature controller has been assembled and incorporated into the furnace pnwer system. Precise temperature ramps can now be produced for temperature programed desorption (TPD) experiments. The control unit consists of an Omega programmable temperature controller model CN-2011 coupled to a solid state relay. A simplified schematic of the control unit is shown in Fig. 15. As currently used, the heater power and controller power originate from the same source. It may prove beneficial to alter the connections so the heater power source is separated from the controller power source. This would allow insertion of i variac to reduce the heater power source. The advantage of this change would be that smaller power pulses could be Impressed upon the heater so the controller could better regulate the heater temperature. (The controller functions by intermittently closing the relay and allowing the full line power to flow 


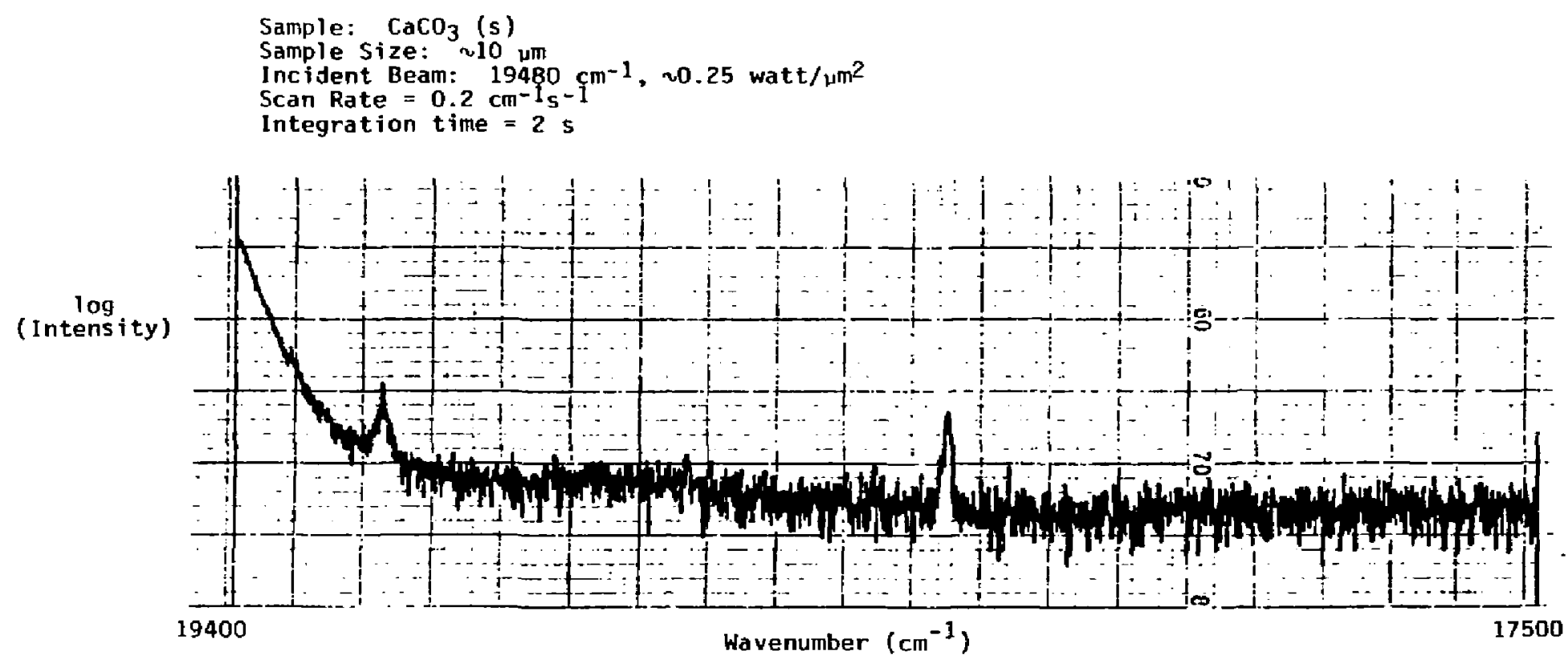

Fig, 14. Raman Spectrum of $\mathrm{CaCO}_{3}$ Obtained Using the Laser Raman Microprobe 


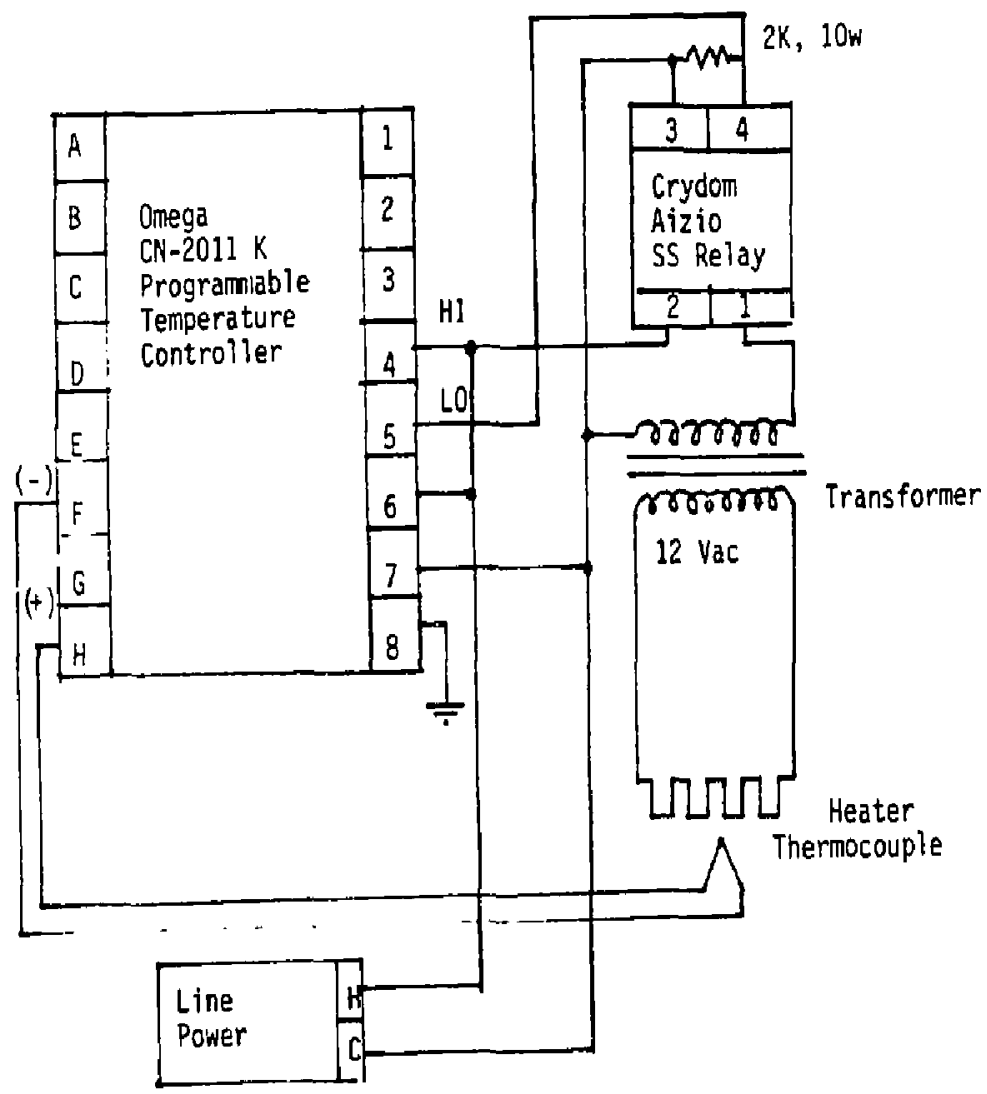

Fig. 15. Sketch of Temperature Control Unit 
through the heater. Presently only very shart bursts of power are required to provide sufficiently high temperatures. A lower source power would perhaps allow the controller to operate using more optimal open/close cycles.)

Figure 16 shows the temperature ramps produced by the present control unit arrangement at two different rates. The lower curves represent a heating rate of $10^{\circ} \mathrm{C} /$ minute. The furnace was heated from $50^{\circ} \mathrm{C}$ to $150^{\circ} \mathrm{C}$ in ten minutes. The legend in the center of the figure shows the scale of a $5^{*}$ difference. (The actual $y$-axis is the thermocouple voltage, mV. For a type $k$ thermocouple in this temperature range, the temperature vs. voltage curve is sufficiently linear for our purposes.) The upper curves were obtained by heating from $100^{\circ} \mathrm{C}$ to $150^{\circ} \mathrm{C}$ in ten minutes, or $5^{\circ} \mathrm{C} / \mathrm{min}$.

The dashed lines superimposed on the heating curves show them to be linear over nearly the entire range. Both experimental curves show slight oscillations about this ideal ramp. The higher heating rate shows the greater oscillation, which is typically $1^{\circ} \mathrm{C}$ different than the ideal value. Both curves deviate from Ideality at the start of the experiment, about the first 30-45 seconds. The furnace was heated to near the starting temperatures before the experiments were begun. This may be due to the lag in the heating of the thermocouple by the furnace that has been noted before. It is estimated that the sample inside the cruclble may be about $20^{\circ} \mathrm{C}$ cooler than the themocouple. future experiments using samples of well-known desorotive properties will be used to calfbrate the actual sample temperature against the thermocouple value of the furnace. Since the lag occurs at the low temperature end of the ramp, it will not interfere with the working range (expected to be above $100^{\circ} \mathrm{C}$ for most glasses) and so will not be of concern at this point.

These experiments have also shown the furnace to overshoot the final temperature, probably due to the temperature lag associated with the crucible. Agaln, this should not present any complications in TPD experiments.

Finally, Fig. 17 shows a TPD spectrum of a hydrated glass. The sample, supplied by J. Abrajano (CMT), consisted of a simple soda sllica glass hydrated with $\mathrm{D}_{2} \mathrm{O}$. The layer thickness was approximately $1 \mu \mathrm{m}$. The spectrum shows the $\mathrm{m} / \mathrm{e}=19$ peak $\left(\mathrm{HDO}^{+}\right)$as a function of the furnace 


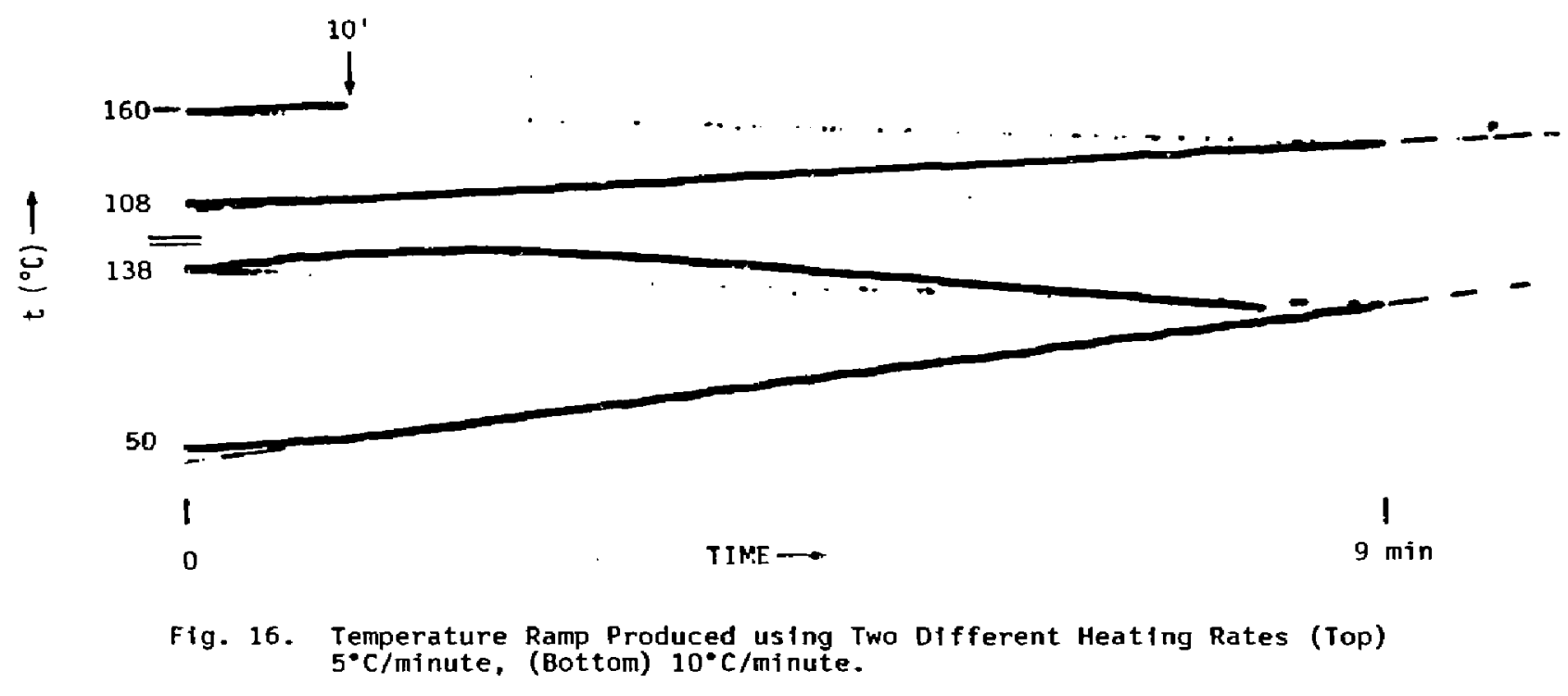




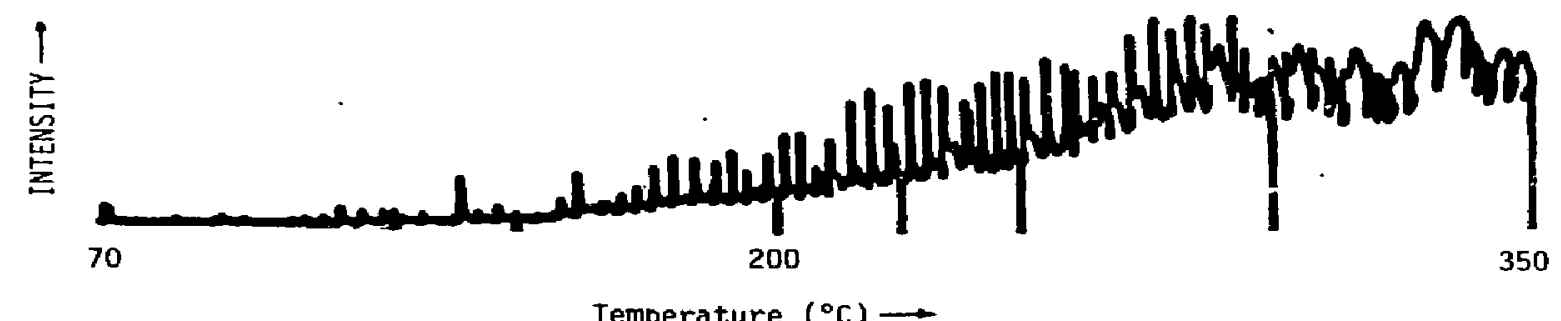

Fig. 17. TPD Spectra, m/e $=19 \mathrm{HDO}$, of Hydrated Glass 
temrerature. Famllitar bursts were observed up to a temperature near $300^{\circ} \mathrm{C}$. These have been postulated to arise from fluid inclusions that ruptured as the pressure inside the inciusion was sufficient to pop the weakened glass and so vaporize the inclusion. The high temperature side of these bursts have exponential-like decay patterns probably reflective of the pumping speed of the chamber pumps. The rise in the background level starting at about $150^{\circ} \mathrm{C}$ may be due to the bulldup of $\mathrm{HDO}^{+}$in the chamber due to too slow pumping or may be due to release of $\mathrm{HOO}^{+}$through another mechanism, for example, evaporation from the glass structure as opposed to inclusions. other workers have found a broad desorption peak centered near $400^{\circ} \mathrm{C}$ for simflar samples using thermogravimetric analysis. This latter technique does not distinguish the chemical nature of the desorbing species, but rather measures the weight change of the sample.

At temperatures greater than $300^{\circ} \mathrm{C}$ the release pattern is somewhat different from the bursts seen earlier. The bursts are much broader and not nearly as peaked. It appears that the pumping speed of HDO is sufficient to prevent appreciable background buildup. It is presently speculated that the surface is melting and water is being driven from hydrated layer. The inclusions are probably all decrepitated at this point.

Minor problems in the temperature control are evident between $300^{\circ} \mathrm{C}$ and $350^{\circ} \mathrm{C}$ where the spectrum can be seen to turn back on itseli as the furnace radiatively cools before the temperature controller provides another power burst. This can hopefully be remedled by an adjustment in the control unit.

Another experiment using a fresh plece of $0_{2} \mathrm{O}$ hydrated glass is scheduled shortly. This time the TPO spectrum of $\mathrm{HDO}^{+}$will be collected for temperatures to near $600^{\circ} \mathrm{C}$. A smaller sample size will be used in an effort to reduce further the possibility of too slow pumping speeds contributing io the background level. 
V. GLASS ANALOG STUDIES

(QA level III, activity \#D-20-31)

The goal of this study has been to develop analytical techniques to investigate how glass changes when reacted in water and to relate reactions that occur in natural glass to those found in nuclear waste glasses. It is generally recognized that when such a reaction occurs a gel layer forms on the surface of unreacted glass. The interest lies in learning:

(1) How does the gel layer grow with time?

(2) What is the composition of the gel layer?

(3) Is the gel layer homogeneous with respect to composition?

(4) If the layer is heterogeneous, how does the composition change?

The SEM/EDS system deseribed previously allows qualitative analysis to be performed on points or "spots," on small areas, and also allows collection of line profiles, which measure concentration changes along a line. These collected spectra are then converted to quantitative ousput using the Princeton Gamma Tech (PGT) System 4 software. The software being used consists of a standard library rostine, BSTAND, and a sample measurement routine, BSAM. In order to demonstrate the facility of the system and software, and to establish the reproducibility of the technique, a series of exercises were initiated. These exercises consisted of taking a set of glass standards (known concentrations) and using them to analyze each other as unknowns. The effort spent in quantifying the system is necessary because currently the bulk glass is used as a standard when analyzing the reacted layers, and a full understanding of all the processes that affect quantitative measurements will aid in interpreting the results of layer analyses.

The glass standards and samples were mounted in cross-section in epoxy and polished with diamond and/or alumina polish $(0.05 \mu)$. Previousiy mounted samples [BYERS] were found to have developed cracks between the glass and epoxy, making layer thickness measurements and line profile analysis impossible. It was found that by mounting sample in Epoxide TM resin and hardener (Buehler, Ltd.), allowing at least 24 hours for the mount to set, followed by polishing (several minutes 600 grit carborundum paper followed by an ultrasonic rinse and 3-4 hours of polish in a vibratory polisher, Alumina $0.3 \mu$ ) the cracking problem did not develop. 
This polishing procedure has been used on all samples and standards subsequently mounted. The polished samples had been coated with carbon in an evaporating coaier, prevlously used primarily for samples only examined in the SEM.

The Itial exercise of establishing the reproducibility of the system used three SRL type standard glasses which contained $2 \%, 5 \%$, and $8 \% \mathrm{C}_{3} 0$ and an NBS standard glass (basalt glass, USNM 111240) Table 20. It was found that the SRL glasses could be used to analyze each other very well (inoividuai elemelits $10 \%$ of known values, total compositivi $100 * 2 \%$ ). However, these standards were ursuitable for analyzing the basalt glass. Caicium and iron, in particular, were not rellably analyzed. The total composition was $100 * 20 \%$, al though when the total analysis was normalized to $100 \%$, the analysis for individual elements 1mproved. A meeting with a PGT techniclan suggested that tile compositions of the standards were different enough to produce the differences observed. He belleved new standards along with careful collection of spectra would elfminate these problems.

New standards were obtained $f$ in the Smithsonian Institute. These glass standards consisted of three basaltic glasses. The basalt glass C. Bysrs used in his analog study was also analyzed by Analytical Chemistry Laboratory (ACL) for later use as a standard. The compositions of these four glasses are given in Table 20. These standards were used to analyze each other. In collecting these spectra it was discovered that the SEM current stabilized after one hour and the area collected was inconsequential. It was also found that samples that had been prepared separately required normalization to obtain comparable results. Such normalization indicated that while the relative amounts of the individual elements were in the correct proportions, the spectra were not being collected under identicai conditions. It was decided that this was due to different carbon coatings on each mount. This was tested by coating two different mounts using a carbon evaporator at Northwestern University used in confunction with their electron microprobe. This higher quality coater produced analyses among the four basalt glass standards that were identical to the known values within the analytical error. A suitable carbon coater has been purchased and is presently being installed. 
Table 20. Composition of Glass Standards (wt g)

\begin{tabular}{|c|c|c|c|c|c|c|c|}
\hline & $\begin{array}{l}\text { USNM } \\
111240\end{array}$ & $\begin{array}{l}\text { USNM } \\
113498\end{array}$ & $\begin{array}{l}\text { USNM } \\
113716\end{array}$ & $2 \%$ SRL & $5 \%$ SRL & $8 \%$ SRL & $\begin{array}{l}\text { C. Byers' } \\
\text { Basalt }\end{array}$ \\
\hline & US1 & US2 & US3 & 2SRL & 5SRL & 8SRL & Basalt \\
\hline $\mathrm{Li}$ & & & & 1.38 & 1.37 & 1.35 & \\
\hline$B$ & & & & 2.39 & 2.26 & 2.23 & \\
\hline $\mathrm{Na}$ & 1.93 & 1.97 & 1.34 & 12.03 & 11.21 & 11.25 & 3.36 \\
\hline $\mathrm{Mg}$ & 4.06 & 3.06 & 4.95 & & & & 3.63 \\
\hline A1 & 7.45 & 6.61 & 8.14 & 2.11 & 2.21 & 2.11 & 7.09 \\
\hline $\mathrm{Si}$ & 23.80 & 23.81 & 24.09 & 21.85 & 21.57 & 21.22 & 23.05 \\
\hline P & 0.06 & 0.26 & 0.05 & & & & \\
\hline$s$ & & & & 0.10 & 0.14 & 0.12 & \\
\hline K & 0.16 & 0.68 & 0.07 & & & & 0.52 \\
\hline $\mathrm{Ca}$ & 7.98 & 6.65 & 8.08 & 1.71 & 3.80 & 5.63 & 7.38 \\
\hline $\mathrm{Ti}$ & 1.10 & 2.43 & 0.78 & & & & 1.04 \\
\hline$M n$ & 0.16 & 0.09 & 0.11 & 2.36 & 2.39 & 2.36 & 0.14 \\
\hline $\mathrm{Fe}$ & 9.21 & 10.34 & 7.10 & 10.11 & 8.69 & 8.67 & 8.81 \\
\hline Ni & & & & 1.21 & 0.86 & 0.87 & \\
\hline $\mathrm{Ce}$ & & & & & 0.60 & & \\
\hline Nd & & & & & 0.63 & & \\
\hline 0 & 44.09 & 44.20 & 44.79 & 44.75 & 44.27 & 44.20 & 44.88 \\
\hline Total & 100.00 & 100.00 & 100.00 & 100.00 & 100.00 & 100.00 & 100.00 \\
\hline
\end{tabular}


While the problems of analyzing bulk glass appear to have been solved, the extension of the technique to reacted glass is veing made. It appears that shorter collection times may be required because the probe current drifts if left on reacted glass for longer than 100 seconds. Another option is to use a smaller probe current. The $x$-ray detector is currently being overhauled by PGT after degradation in the energy resolution was noted.

To summarize, sample preparation techniques (sample mounting and polishing) have been developed which meet our analytical needs. A carbon coater suitable for quantitative analysis is being installed. The analytical technique is being extended to analyze reacter glasses. 


\section{REFERENCES}

BARKATT

A. Barkatt, A. Barkatt, and W. Sousanpour, Nucl. Technol, 60, 218 (1983). NNA.891101.0002

\section{BATES-1}

J. K. Bates et al., "NWWSI Waste Form Testing at Argonne Nacional Laboratory, Semiannua] Report, January-June 1986," Lawrence Livermore National Laboratory report UCRL-15801-86-1 (1988). NNA.B7 1'218.0006

\section{BATES-2}

J. K. Bates et al., "NNWSI Waste Forth Testing at Argonne Natiorial Laboratory, Semiannual Report, July-December 1986," !awrence Livermore National Laboratory report UCRL-15801-86-2 (1989). NNA.900315.0278

\section{BATES-3}

J. K. Bates and T. J. Gerding, "One Year Results of the NNWSI Unsaturated Test Procedure: SRL 165 Glass Application," Argonne National Laboratory report ANL-85-41 (1986). NNA.870903.0081

\section{BATES-4}

J. K. Bates and H. J. Steindler, Science 218, 51 (1982), NNA.891101.0005

\section{BATES-5}

J. K. Bates, D. F. Fischer, and T. J. Gerding, "The Reaction of Glass

In a Gamma Irradiated Saturated Tuff Environment, Part: 1: SRL 165 Glass," Argonne National Laboratory report ANL-85-62 (1986). NNA. $891101.000 B$

\section{BATES-6}

J. K. Bates, O. F. Fischer, and T. J. Gerding, "The Reaction of Reference Commerclal Nuclear Waste Glasses during Gama Irradiation in a Saturated Tuff Environment," J. Mater. Res. 3(3), 576-579 (May/June 1988). NNA.900125.0073

\section{BATES-7}

J. K. Bates, T. J. Gerding, D. F. Fischer, and W. L. Ebert, "The Reaction of Glass in a Garma Irradiated Saturated Tuff Environment, Part II: Data Package for ATM-1c and ATM-8 Glasses," Lawrence Livemore National Laboratory report UCRL-15991, SANL 610-008 (1988). NNA.871215.0034

\section{BATES-8}

J. K. Bates and V. H. Oversbj, in Scientific Bas/s for Nuciear Haste Management VIII, Vol. 44, eds. C. M. Jantzen, J. A. Stone, and R. C. Ewing, Materials Research Society, Pittsburgir, PA, p. 257 (1985). NNA.891101.0010 
BAZAN

F. Bazan, J. Rego, and R. D. Aines, in Scientific Basis for Nuclear Waste Management $X, V 01 . B 4$, eds. J. K. Bates and $W, B$. Seefeldt, Materials Research Society, Pittsburgh, PA, p. 447 (1987). NNA.891108.0048

BURNS

W. G. Burns et al., J. Nucl. Mat. 107, 245 (1982). NNA.891101.0027 BYERS

C. D. Byers, M. J. Jercinovic, and R. C. Ewing, "A Study of Natural Glass Analogues as Applied to Alteration of Nuclear Waste Glass," Argonne Nationdl Laboratory report ANL-86-46 (1987). SRX.870720.0172 KIM

J. I. Kim, H. Bernkopf, C. H. Llerse, and F. Kopold, in ACS Symp. Ser. No. 246, eds. G. S. Barney, J. Navratil, and W. Schulz, American Chemical Society, 115-134 (1984). LOKKEN

R. O. Lokken and D. H. Strachan, in Advances in Ceramics, Vol. 8 , Nuclear Waste Management, eds, G. G. Wicks and W. A. Rass, The American Ceranic Society, Inc., Columbus OH, p. 39 (1984). NNA.891120.0013

MAUPIN

G. D. Maupin, W. M. Bowen, and J. L. Daniel, "Fabrication and Characterization of MCC Approved Testing Material - ATM-10 Glass," Pacific Northwest Laboracory report PNL-5577-10 (1988).

MCVAY-1

G. McVay and L, Pederson, J. Am. Ceram. Soc. 64, 154 (1981). NNA.891109.0053

McVAY-2

G. L. McVay and G. R. Robinson, Pacific Horthwest Laboratory report PNL-4897 (1984). HQS.880517.2496

PLODINEC

M. J. Plodinec, G. G. Wicks, and N. E. Bibler, Savannah River Laboratory report DP-1629 (1982). H(05.880517.2525

STEINDLER

M. J. Steindler et al., "Quarterly Progress Report, Nuclear Fuel Cycle Section," Argonne National Laboratory topical reports ANL-84-37, ANL-84-47, and ANL-84-91 (1984). NNA.900125.0072, NNA.891101.0011, and NNA.891101.0012 
The following number is for Office of Civilian Radioactive Waste Management Records Management purposes only and should not be used when ordering this document:

Accession Number: NNA.891206.0124 